Prepared in cooperation with the U.S. Army Corps of Engineers

Two-Dimensional Hydrodynamic Modeling and Analysis of the Proposed Channel Modifications and Grade Control Structure on the Blue River near Byram's Ford Industrial Park, Kansas City, Missouri

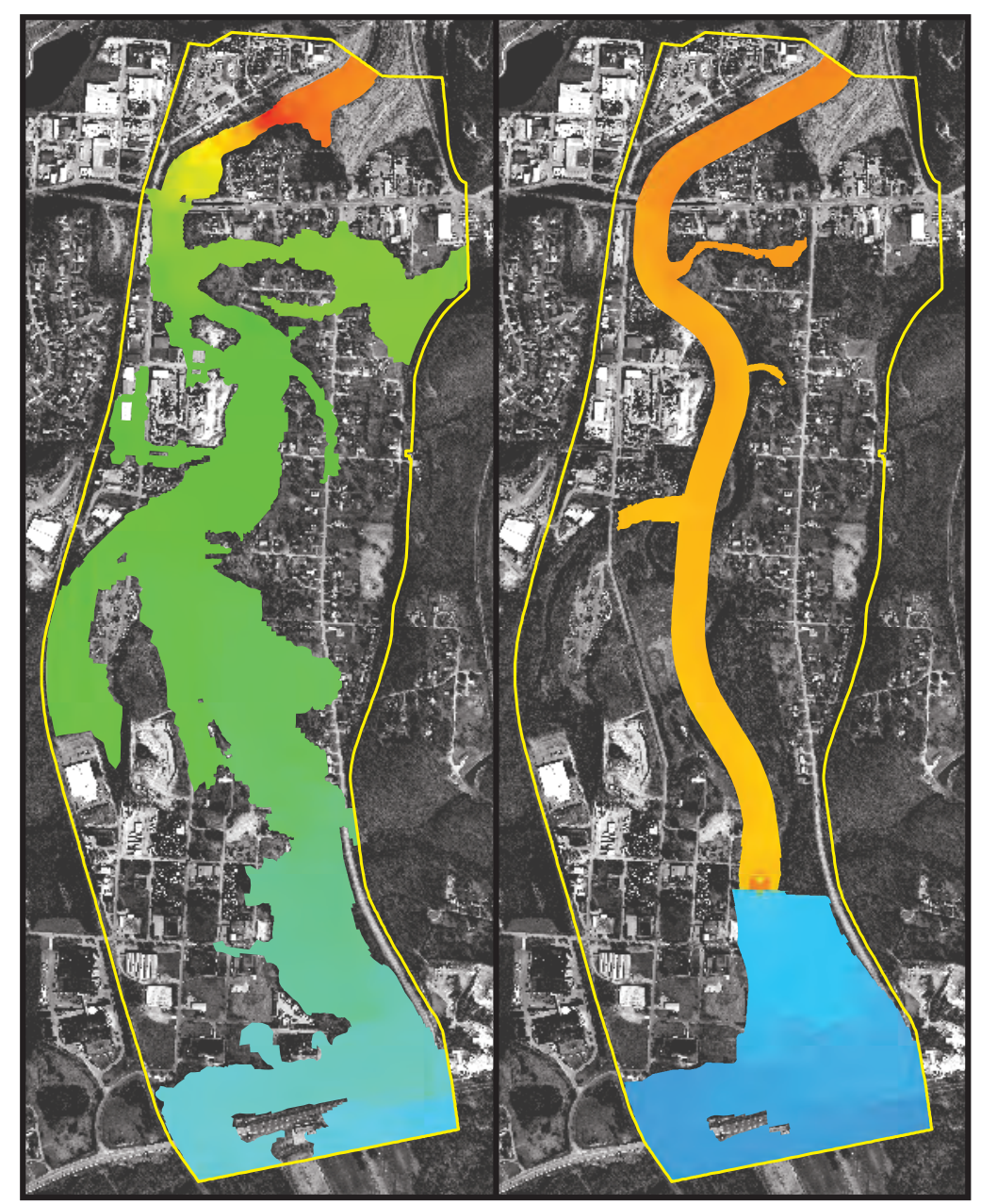

Scientific Investigations Report 2007-5098 
Cover graphic: Simulated water-surface elevations on the Blue River in Kansas City, Missouri, for the 30-year flood from the model of existing conditions (left) and the model of proposed conditions (right). 


\section{Two-Dimensional Hydrodynamic Modeling and Analysis of the Proposed Channel Modifications and Grade Control Structure on the Blue River near Byram's Ford Industrial Park, Kansas City, Missouri}

By Richard J. Huizinga

Prepared in cooperation with the U.S. Army Corps of Engineers

Scientific Investigations Report 2007-5098 


\section{U.S. Department of the Interior DIRK KEMPTHORNE, Secretary}

\section{U.S. Geological Survey \\ Mark D. Myers, Director}

\section{U.S. Geological Survey, Reston, Virginia: 2007}

For product and ordering information:

World Wide Web: http://www.usgs.gov/pubprod

Telephone: 1-888-ASK-USGS

For more information on the USGS--the Federal source for science about the Earth, its natural and living resources, natural hazards, and the environment:

World Wide Web: http://www.usgs.gov

Telephone: 1-888-ASK-USGS

Any use of trade, product, or firm names is for descriptive purposes only and does not imply endorsement by the U.S. Government.

Although this report is in the public domain, permission must be secured from the individual copyright owners to reproduce any copyrighted materials contained within this report.

Suggested citation:

Huizinga, R.J., 2007, Two-dimensional hydrodynamic modeling and analysis of the proposed channel modifications and grade control structure on the Blue River near Byram's Ford Industrial Park, Kansas City, Missouri: U.S. Geological Survey Scientific Investigations Report 2007-5098, 45 p. 


\section{Contents}

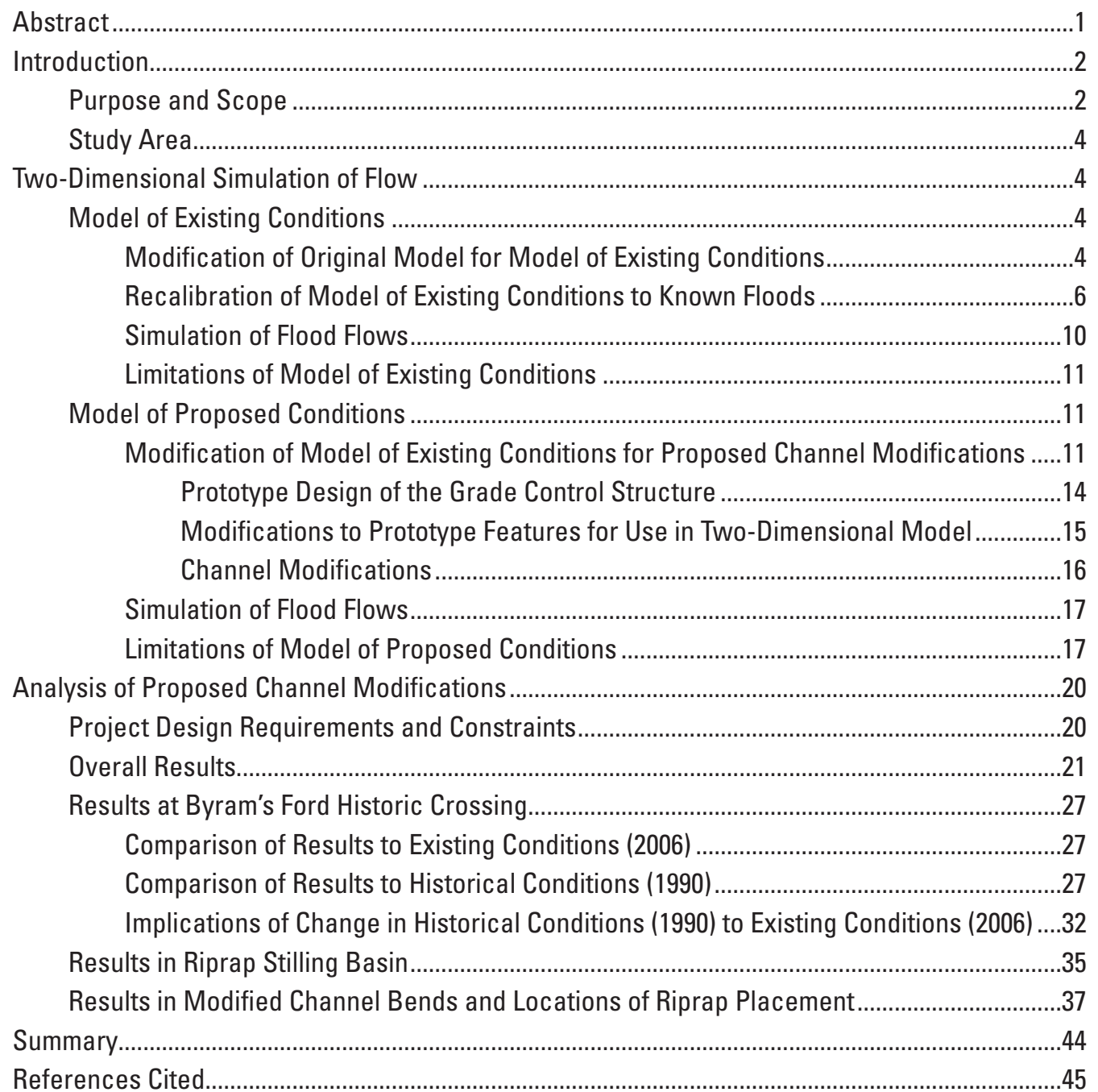




\section{Figures}

1. Map showing study area and channel modifications on the Blue River in Kansas City, Missouri.

2. Aerial photographs showing boundaries of original model and models of existing and proposed conditions on the Blue River in Kansas City, Missouri

3. Map showing land-use coverages used in the model of existing conditions on the Blue River

4-6. Aerial photographs showing-

4. Measured and simulated water-surface elevations from the model of existing conditions for the floods of $(A)$ May 15, 1990, and (B) May 19, 2004, on the Blue River.....

5. Simulated water-surface elevations on the Blue River from the model of existing conditions for the $(A)$ 30-year, $(B)$ 50-year, and $(C)$ 100-year floods...........12

6. Proposed channel modifications on the Blue River

7. Orthographic projection of the proposed grade control structure and levees on the Blue River

8. Map showing finite element mesh with contours in the vicinity of the proposed grade control structure depicting nearly vertical wall construction...

9. Graph showing cross section of the Blue River channel after proposed modifications

10. Map showing land-use coverages used in the model of proposed conditions on the Blue River

11-21. Aerial photographs showing-

11. Simulated water-surface elevations on the Blue River from the model of proposed conditions

12. Results in the vicinity of Byram's Ford Industrial Park on the Blue River for the 100-year flood

13. Approximate placement of overbank roughness material near 63d Street and the vicinity of Byram's Ford Industrial Park on the Blue River in the Waterways Experiment Station (WES) physical model .

14. Simulated results in the vicinity of Byram's Ford on the Blue River for the 30-year flood.

15. Simulated results in the vicinity of Byram's Ford on the Blue River for the 50 -year flood.

16. Simulated results in the vicinity of Byram's Ford on the Blue River for the 100-year flood

17. Simulated results in the vicinity of Byram's Ford on the Blue River for the discharge from the flood of May 15, 1990

18. Simulated water-surface elevations in the vicinity of Byram's Ford Industrial Park on the Blue River for the discharge from the flood of May 15, 1990

19. Simulated results in the vicinity of Byram's Ford on the Blue River for the discharge from the flood of May 15, 1990

20. Simulated velocity magnitudes on the Blue River from the calibration to the flood of May 19, 2004

21. Simulated velocity magnitudes on the Blue River for the discharge from the flood of May 15, 1990 
22-24. Maps showing-

22. (A) Depth-averaged velocity magnitudes simulated in the model of proposed conditions and $(B)$ channel-bottom velocity magnitudes as measured 2 feet above the channel bed in the Waterways Experiment Station (WES) physical model.

23. Simulated velocity magnitudes through the grade control structure and into the modified channel from the model of proposed conditions for the $(A)$ 30-year, $(B)$ 50-year, and $(C)$ 100-year floods on the Blue River

24. Simulated water-surface elevations with contours from the models of $(A)$ existing conditions and $(B)$ proposed conditions for the 100 -year flood on the Blue River.

25. Aerial photograph showing simulated velocity magnitudes throughout the modified channel downstream from the grade control structure from the model of proposed conditions for the $(A) 30$-year, $(B)$ 50-year, and $(C)$ 100-year floods on the Blue River.

\section{Tables}

1. Material and hydraulic properties of various land-use coverages resulting from calibration runs of the model of existing conditions and additional land-use coverages used in the model of proposed conditions ..

2. Measured and simulated water-surface elevations for calibration floods of May 15, 1990, and May 19, 2004.

3. Measured and simulated cross-sectional area and area-weighted average velocity at discharge measurement locations for the calibration flood of May 19, 2004

4. Discharge and water-surface elevations associated with various

recurrence-interval floods from section 10.45 in the Hydrologic Engineering Center's River Analysis System (HEC-RAS) model.

5. Modification of baffle block width in the pier module based on depth of flow in the concrete stilling basin.

6. Simulated water-surface elevations along the channel centerline upstream from the proposed grade control structure for the 30-year and 100-year floods on the Blue River

7. Discharges for selected locations for the 30 -year and 100 -year floods on the Blue River

8. Water-surface elevations in the modified channel downstream from the proposed grade control structure on the Blue River...

9. Water-surface elevations along the left trail levee downstream from the proposed grade control structure for the 30-year flood 35,000 cubic feet per second) on the Blue River

10. Change in water-surface elevation from the downstream boundary to the upstream end of the modified channel from the model of proposed conditions on the Blue River

11. Maximum simulated results in the vicinity of Byram's Ford on the Blue River

12. Simulated water-surface elevations along the modified channel centerline downstream from the proposed grade control structure for the 30-year, 50-year, and 100-year floods on the Blue River 


\section{Conversion Factors and Datums}

Inch/Pound to SI

\begin{tabular}{lll}
\hline \multicolumn{1}{c}{ Multiply } & \multicolumn{1}{c}{ By } & \multicolumn{1}{c}{ To obtain } \\
\hline inch (in.) & Length & \\
foot $(\mathrm{ft})$ & 2.54 & centimeter $(\mathrm{cm})$ \\
mile $(\mathrm{mi})$ & 0.3048 & meter $(\mathrm{m})$ \\
\hline & 1.609 & kilometer $(\mathrm{km})$ \\
\hline square foot $\left(\mathrm{ft}^{2}\right)$ & Area & square meter $\left(\mathrm{m}^{2}\right)$ \\
square mile $\left(\mathrm{mi}^{2}\right)$ & 0.09290 & square kilometer $\left(\mathrm{km}^{2}\right)$ \\
\hline & 2.590 & \\
\hline foot per second $(\mathrm{ft} / \mathrm{s})$ & Flow rate & meter per second $(\mathrm{m} / \mathrm{s})$ \\
cubic foot per second $\left(\mathrm{ft}^{3} / \mathrm{s}\right)$ & 0.3048 & cubic meter per second $\left(\mathrm{m}^{3} / \mathrm{s}\right)$ \\
\hline & 0.02832 & meter per kilometer $\left(\mathrm{m} / \mathrm{km}^{2}\right)$ \\
\hline foot per mile $\left(\mathrm{ft} / \mathrm{mi}^{2}\right)$ & Hydraulic gradient & \\
\hline cubic foot per second per foot $\left[\left(\mathrm{ft}^{3} / \mathrm{s}\right) / \mathrm{ft}\right]$ & 0.1894 & cubic meter per second per meter \\
\hline
\end{tabular}

Vertical coordinate information is referenced to the North American Vertical Datum of 1988 (NAVD 88).

Horizontal coordinate information is referenced to the North American Datum of 1983 (NAD 83).

*Unit discharge: The standard unit for unit discharge is cubic foot per second per foot [(ft3/s)/ft]. In this report, the mathematically reduced form, foot squared per second $\left(\mathrm{ft}^{2} / \mathrm{s}\right)$, is used for convenience. 


\title{
Two-Dimensional Hydrodynamic Modeling and Analysis of the Proposed Channel Modifications and Grade Control Structure on the Blue River near Byram's Ford Industrial Park, Kansas City, Missouri
}

\author{
By Richard J. Huizinga
}

\section{Abstract}

The Blue River Channel Modification project being implemented by the U.S. Army Corps of Engineers (USACE) is intended to provide flood protection within the Blue River valley in the Kansas City, Mo., metropolitan area. In the latest phase of the project, concerns have arisen about preserving the Civil War historic area of Byram's Ford and the associated Big Blue Battlefield while providing flood protection for the Byram's Ford Industrial Park. In 1996, the USACE used a physical model built at the Waterways Experiment Station (WES) in Vicksburg, Miss., to examine the feasibility of a proposed grade control structure (GCS) that would be placed downstream from the historic river crossing of Byram's Ford to provide a subtle transition of flow from the natural channel to the modified channel. The U.S. Geological Survey (USGS), in cooperation with the USACE, modified an existing twodimensional finite element surface-water model of the river between 63d Street and Blue Parkway (the "original model"), used the modified model to simulate the existing (as of 2006) unimproved channel and the proposed channel modifications and GCS, and analyzed the results from the simulations and those from the WES physical model.

Modifications were made to the original model to create a model that represents existing (2006) conditions between the north end of Swope Park immediately upstream from 63d Street and the upstream limit of channel improvement on the Blue River (the "model of existing conditions"). The model of existing conditions was calibrated to two measured floods. The model of existing conditions also was modified to create a model that represents conditions along the same reach of the Blue River with proposed channel modifications and the proposed GCS (the "model of proposed conditions"). The models of existing conditions and proposed conditions were used to simulate the 30-, 50-, and 100-year recurrence floods. The discharge from the calibration flood of May 15, 1990, also was simulated in the models of existing and proposed conditions to provide results for that flood with the current downstream channel modifications and with the proposed channel modifications and GCS.

Results from the model of existing conditions show that the downstream channel modifications as they exist (2006) may already be affecting flows in the unmodified upstream channel. The 30-year flood does not inundate most of the Byram's Ford Industrial Park near the upstream end of the study area. Analysis of the 1990 flood (with the historical 1990 channel conditions) and the 1990 flood simulated with the existing (2006) conditions indicates a substantial increase in velocity throughout the study area and a substantial decrease in inundated area from 1990 to 2006.

Results from the model of proposed conditions show that the proposed channel modifications will contain the 30-year flood and that the spoil berm designed to provide additional flood protection for the Byram's Ford Industrial Park for the 30-year flood prevents inundation of the industrial park. In the vicinity of Byram's Ford for the 30-year flood, the maximum depth increased from 39.7 feet (ft) in the model of existing conditions to $43.5 \mathrm{ft}$ in the model of proposed conditions, with a resulting decrease in velocity from 6.61 to 4.55 feet per second (ft/s). For the 50-year flood, the maximum depth increased from 42.3 to $45.8 \mathrm{ft}$, with a decrease in velocity from 6.12 to $4.16 \mathrm{ft} / \mathrm{s}$ from existing to proposed conditions. For the 100-year flood, the maximum depth increased from 44.0 to $46.6 \mathrm{ft}$, with a decrease in velocity from 5.64 to $4.12 \mathrm{ft} / \mathrm{s}$ from existing to proposed conditions. When the May 15, 1990, discharge is simulated in the model of existing conditions (with the existing (2006) modified channel downstream of the study area), the maximum depth increases from 38.4 to $42.0 \mathrm{ft}$, with a decrease in velocity from 6.54 to $4.84 \mathrm{ft} / \mathrm{s}$ from existing (2006) to proposed conditions.

Analysis of the results from the May 15, 1990, flood (with historical 1990 channel conditions) and the model of proposed conditions, however, indicates that the maximum depth only increases from 41.5 to $42.0 \mathrm{ft}$, with a decrease in velocity from 5.09 to $4.84 \mathrm{ft} / \mathrm{s}$ from historical (1990) to proposed conditions. These results confirm that the downstream 
channel modifications as they exist (2006) may already be affecting flows in the unmodified upstream channel, but they also show that the proposed GCS likely will create conditions similar to those that existed before downstream channel modifications began.

The velocities in the riprap stilling basin downstream from the GCS showed similar trends in the model of proposed conditions and the WES physical model. The maximum velocity in the riprap stilling basin occurs in the center of the channel immediately downstream from the concrete stilling basin of the GCS and decreases in a downstream direction.

Velocity magnitudes in the modified channel downstream from the GCS were remarkably consistent for the 30-, 50-, and 100 -year floods, with the average velocity along the centerline ranging from 7.4 to $7.7 \mathrm{ft} / \mathrm{s}$. A localized maximum velocity of nearly $24.5 \mathrm{ft} / \mathrm{s}$ was simulated for the 100-year flood at the downstream end of the left trail levee where flow from the flood plain reenters the channel. Other localized contractions of flow on the left flood plain resulted in velocities as great as $14.8 \mathrm{ft} / \mathrm{s}$ for the 100 -year flood.

\section{Introduction}

In 1970, Congress granted authorization to the U.S. Army Corps of Engineers (USACE) to begin the Blue River Channel Modification project, which was intended to provide flood protection within the Blue River valley in the Kansas City, Mo., metropolitan area. The project is composed of channel modifications that include elimination of meander bends and a widened channel combined with concrete paving and rock- or stone-protected slopes (U.S. Army Corps of Engineers, 2004). The design capacity of the modified channel is intended to convey the 30-year flood frequency discharge, or 35,000 cubic feet per second $\left(\mathrm{ft}^{3} / \mathrm{s}\right)$. Construction began in 1983 and has progressed upstream from the mouth at the Missouri River to immediately upstream from the mouth of Brush Creek (fig. 1). As of 2006, the project is embarking on Stage III, which involves work from Brush Creek upstream to 63d Street (U.S. Army Corps of Engineers, 2004).

In the early 1990s, concerns over preserving Byram's Ford and the associated Big Blue Battlefield, a Civil War historic area within the area of the proposed Stage III improvement, caused a relocation of the upstream end of channel modifications from 63d Street to a point downstream from the historic battlefield and river crossing. As a result of the relocation of channel modifications, however, concerns were raised over the loss of flood protection that would have been provided by the channel modifications for the Byram's Ford Industrial Park.

In 1996, a report was released by the USACE that examined the feasibility of a proposed grade control structure (GCS) that would be placed downstream from the historic river crossing of Byram's Ford, thereby providing a subtle transition of flow from the natural channel to the modified channel (Cooper, 1996). The USACE used a physical model constructed at the Waterways Experiment Station (WES) in Vicksburg, Miss., for all analyses in the report. The report examined alternatives for the mitigation of potential adverse effects on Byram's Ford from the proposed channel modifications and examined proposed flood protection for the industrial park by using a supplemental spoil berm on the left bank of the unimproved channel between 63d Street and the proposed GCS (the words "left" and "right" refer to directions that would be reported by an observer facing downstream).

As part of a recent study along the Blue River in Kansas City, the U.S. Geological Survey (USGS) in cooperation with the city of Kansas City, Mo., developed flood inundation maps that can be accessed in a real-time manner to identify extents of inundation using stage data from continuous streamflow gaging stations of Kansas City and the USGS (Kelly and Rydlund, 2006). As part of the effort, a two-dimensional hydrodynamic flow model was developed for the complex section of the river between 63d Street and Blue Parkway. The twodimensional model was used to determine the performance of hydraulic structures and existing unimproved channel conditions that represent pronounced meander effects and sinuosity. The proposed channel modifications and GCS are in the area that is covered by the two-dimensional model.

To address the concerns of the various stakeholders of the Byram's Ford Industrial Park and the historic area, as well as to analyze the complex two-dimensional nature of the flow through the proposed GCS, the USGS, in cooperation with the USACE, conducted simulations of flood flows on the Blue River near the Byram's Ford Industrial Park using a modified version of the two-dimensional model. Simulations were done for the existing (unimproved) channel conditions and for conditions representing the proposed channel modifications and GCS.

\section{Purpose and Scope}

This report describes the development of and results from two-dimensional hydrodynamic flow models that represent a portion of the Blue River in Kansas City, Mo., which contains the historic Civil War river crossing of Byram's Ford, using the depth-averaged flow model Flo2DH (part of the Federal Highway Administration's Finite Element SurfaceWater Modeling System (FESWMS) designed for hydraulic structures and flood plains (Froehlich, 2002)). Modifications were made to an existing two-dimensional hydrodynamic flow model developed for the area between 63d Street and Blue Parkway on the Blue River (Kelly and Rydlund, 2006; hereinafter referred to as the "original model") to create a new model that represents conditions as they exist (as of 2006) between the north end of Swope Park (immediately upstream from 63d Street) and the upstream limit of channel improvement on the Blue River located approximately 800 feet (ft) upstream from Brush Creek (hereinafter referred to as the "model of existing conditions"). Further modifications were made to the model of 

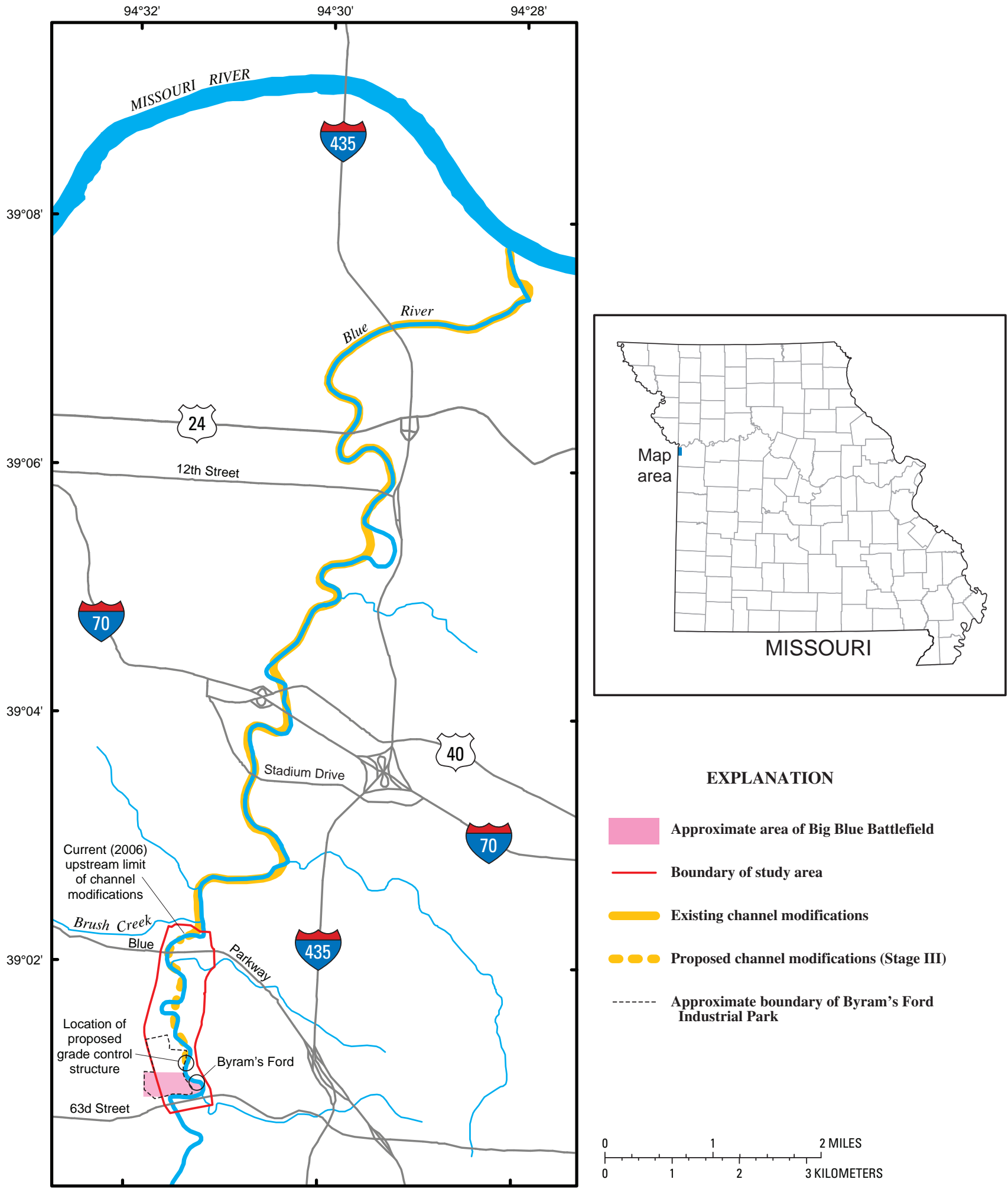

\section{EXPLANATION}

Approximate area of Big Blue Battlefield

Boundary of study area

Existing channel modifications

Proposed channel modifications (Stage III)

Approximate boundary of Byram's Ford Industrial Park

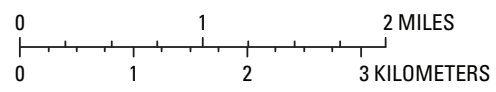

Base from U.S. Geological Survey digital data, 1:24,000, 1996

Universal Transverse Mercator projection, Zone 15

Horizontal coordinate information referenced to the North American

Datum of 1983 (NAD 83)

Figure 1. Study area and channel modifications on the Blue River in Kansas City, Missouri. 
existing conditions to create another model that represents conditions along the same reach of the Blue River with proposed channel modifications and the proposed GCS in place (hereinafter referred to as the "model of proposed conditions").

The results from the model of existing conditions and the model of proposed conditions are presented for the 30-, 50-, and 100-year recurrence floods, as well as for the discharge from a flood that occurred on May 15, 1990. Results from the physical model of the GCS done at the WES also are presented, as documented in Cooper (1996; hereinafter referred to as the "WES physical model"). Finally, velocities from the model of proposed conditions at bends in the modified channel and other areas of interest are presented for the various floods to permit the USACE to assess the adequacy of the design of riprap in these areas.

\section{Study Area}

The study area is a portion of the Blue River in Kansas City, Mo. (figs. 1 and 2). The study area begins near river mile (mi) 10.45, upstream from the mouth of Brush Creek near the current (2006) upstream limit of channel modifications, and ends near river mi 12.74 in Swope Park, immediately upstream from 63d Street. The current conditions are described in Kelly and Rydlund (2006) as "a deeply incised channel, sharp meander bends, small tributary junctions, and frequent riffles exhibiting substantial gradient change." In the study area, the left flood plain predominantly consists of industrial land use with impervious areas, and the right flood plain predominantly consists of residential land use. A thick riparian corridor is present along the Blue River and the four unnamed tributaries in the study area, and timber and brush of varying thickness are interspersed throughout the area. The modified Blue River channel extends to the downstream end of the study area. Byram's Ford is located approximately $800 \mathrm{ft}$ downstream from 63d Street, between Hardesty Avenue and the Byram's Ford Industrial Park. The proposed GCS would be placed approximately 1,240 ft downstream from Byram's Ford.

\section{Two-Dimensional Simulation of Flow}

The FESWMS Flo2DH model simulates flow in two dimensions in the horizontal plane. It uses a finite element mesh and the Galerkin finite element method of solving three partial differential equations representing conservation of mass and momentum (Froehlich, 2002). This twodimensional model can simulate longitudinal and lateral variations in water-surface elevations and velocities and can accommodate geometric features, such as highway embankments, bridge structures, channel bends, berms, buildings, and other flow obstructions. A graphical user interface called the Surface-Water Modeling System (SMS; Environmental Modeling Research Laboratory, 1999) was used to construct the two-dimensional finite element mesh, facilitate assignment of roughness coefficients and other hydraulic and material parameters to the mesh elements, execute the model, and evaluate the model output.

A two-dimensional hydrodynamic flow model (the original model) had been developed for a substantial part of the study area as part of a recent flood inundation study along the Blue River in Kansas City (Kelly and Rydlund, 2006). The original model was used to determine hydraulic performance of existing (unimproved) channel conditions that represent pronounced meander effects, sinuosity, and hydraulic structures. The development and calibration of the original model between 63d Street and Blue Parkway is described in Kelly and Rydlund (2006).

\section{Model of Existing Conditions}

The calibrated mesh from the original model was used as the base mesh for development of the model of existing conditions, which was used to provide results for the study area with channel conditions as they currently (2006) exist. The model of existing conditions was in turn used to develop the model of proposed conditions.

\section{Modification of Original Model for Model of Existing Conditions}

The extent of the original model was from the downstream edge of $63 \mathrm{~d}$ Street on the upstream (south) end to the downstream edge of Blue Parkway and the lower Blue Parkway Bridge on the downstream (north) end and from Hardesty Avenue on the east side to the Union Pacific railroad embankment on the west side. These boundaries were extended from the original boundaries upstream and downstream, as well as to the east (fig. 2).

As part of the Blue River Channel Modification project, the USACE has developed a one-dimensional computer model of the lower Blue River using the Hydrologic Engineering Center's River Analysis System (HEC-RAS; Brunner, 2002) (hereinafter referred to as the "HEC-RAS model"). The HECRAS model has been used as a design tool by the USACE to update channel profiles as modifications have progressed upstream on the Blue River. The HEC-RAS model consists of cross sections at regular intervals throughout the Blue River mainstem, including one immediately upstream from the mouth of Brush Creek (at river mi 10.45, hereinafter referred to as "section 10.45"). Results from the HEC-RAS model were used by Kelly and Rydlund (2006) to develop the flood inundation information along the Blue River in areas upstream and downstream from the boundaries of the original model. Results from the original model were made consistent with results at section 10.45 of the HEC-RAS model by way of a short HEC-RAS reach described and referred to in Kelly and Rydlund (2006) as the "constructed HEC-RAS model."

A direct connection between the original model and the HEC-RAS model was desired for consistency, so the origi- 


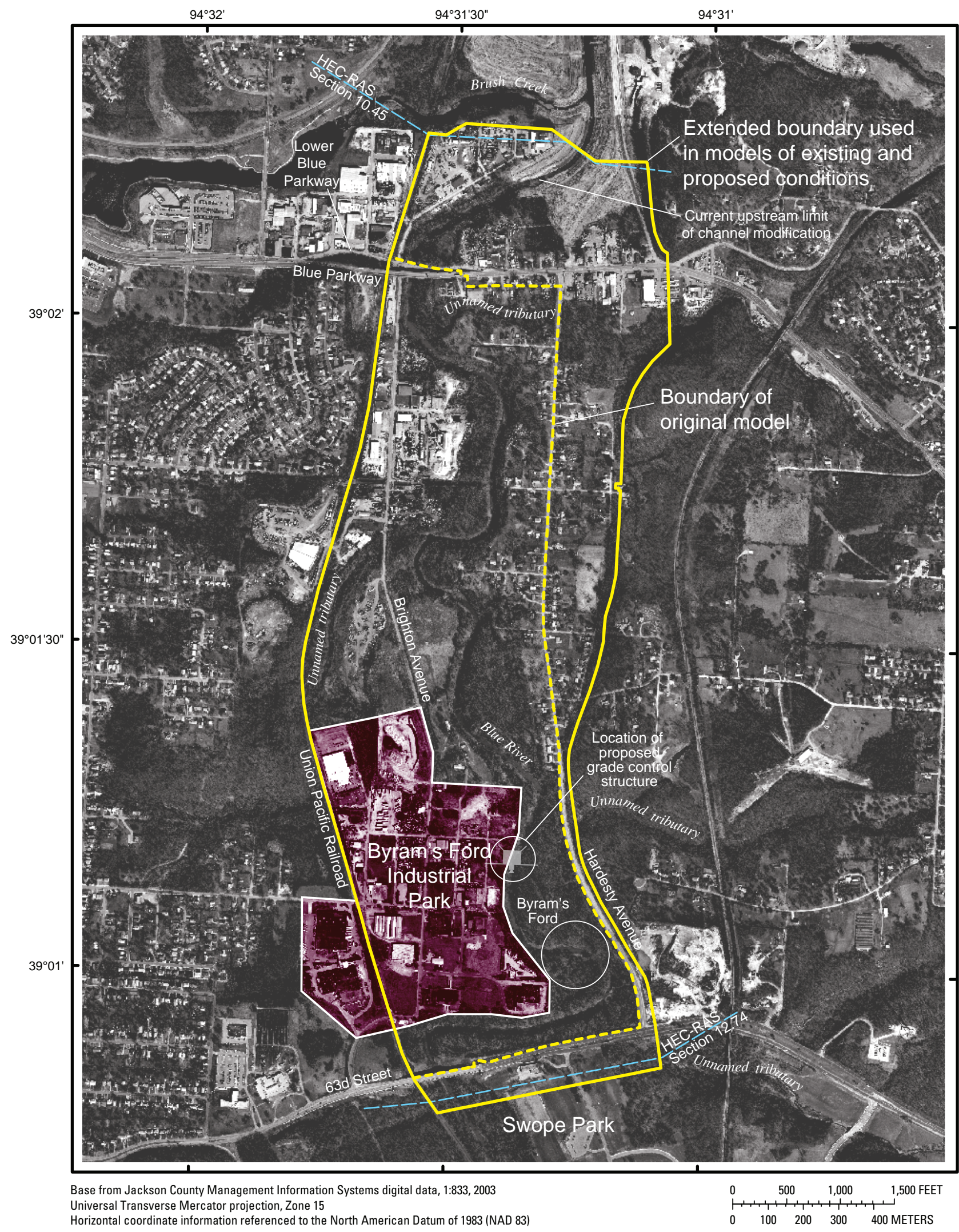

Figure 2. Boundaries of original model and models of existing and proposed conditions on the Blue River in Kansas City, Missouri. 
nal model was extended downstream about $0.25 \mathrm{mi}$ from the original boundary along Blue Parkway and the lower Blue Parkway Bridge to section 10.45. This extension provided several benefits, in addition to providing direct comparability and connection to the HEC-RAS model. It extended the study area to the location of a hydroacoustic discharge measurement taken during a flood on May 19, 2004, thereby providing another point of reference in the calibration, and it permitted modeling of the existing conditions on the Blue River beginning at the current (2006) upstream end of modifications, thereby encompassing the full extent of the proposed channel modifications.

The original model was extended upstream about $0.1 \mathrm{mi}$ into Swope Park from the original upstream boundary along the downstream edge of $63 \mathrm{~d}$ Street (fig. 2). This extension was made to permit full expansion of flow across Swope Park and 63d Street for the full effective width of the flood plain upstream from 63d Street, particularly for the 100-year discharge that would overtop 63d Street under existing (2006) conditions.

The original model also was extended from Hardesty Avenue east of the Blue River to the flood plain valley wall (fig. 2). Kelly and Rydlund (2006) assumed that flow in this area was essentially ineffective, but the extension to the east was required to accommodate the extensions upstream and downstream and to provide for a more robust and stable model that extended from the east to west edges of the flood plain.

Piers in the main channel for the existing Blue Parkway Bridge and the adjacent downstream lower Blue Parkway Bridge had been incorporated in the mesh of the original model (Kelly and Rydlund, 2006). The model of existing conditions was to be used for flows out of the main channel; therefore, the piers for the $63 \mathrm{~d}$ Street Bridge and the overbank piers of the existing Blue Parkway Bridge had to be incorporated into the model of existing conditions. Because flow around these overbank piers will not substantially affect flow in the model, the pier module in FESWMS was used to incorporate these additional piers rather than using hard-coded elements to represent each pier as had been done by Kelly and Rydlund (2006). Position, orientation, and dimensions of each pier were taken from bridge plans (Missouri Department of Transportation, 1935) to accurately position and size the piers.

After modification, the finite element mesh for the model of existing conditions consisted of 46,649 elements. Each element had a node at each corner and at the midpoint of each side, which created a total of 120,941 nodes.

\section{Recalibration of Model of Existing Conditions to Known Floods}

A particular flow scenario cannot be simulated directly because the model cannot be started with boundary conditions that exactly represent the true conditions (Huizinga and Rydlund, 2001; Kelly and Rydlund, 2006). The true conditions that are to be simulated are reached in a process called spin- down. In a subcritical flow regime, spindown involves starting the model with the desired discharge as the upstream boundary condition and a downstream water-surface elevation that is higher than the highest land-surface elevation in the mesh. This condition must be met so that all nodes and elements in the model are "wet" (having a positive depth of flow). The model is run with these conditions for a sufficient number of iterations to cause the water-surface elevation changes between iterations to be minimized within a preset limit. Once the limit is reached, the model is said to have "converged." The downstream water-surface elevation is then decreased by some finite amount, the model is restarted using the results of the previous run - called a hotstart - as the starting point for the new run, and the model is run until convergence occurs. This process is repeated until the desired downstream watersurface elevation is reached, as dictated by high-water marks, flood profiles, or other known site parameters. During the spindown process, if the simulated water-surface elevation at a particular node is less than the land-surface elevation assigned to the node, then the node is said to "go dry." If one or more of the nodes for a particular element go dry, then the element goes dry, and the element is not included in the computations during that iteration. As the simulation proceeds through iterations, an element can oscillate between wet and dry, which can lead to solution instability and a loss of convergence. To limit this instability, the user sets a tolerance on the depth of flow over a node (the storativity depth, table 1 , combined with a default "depth tolerance for drying" of $0.5 \mathrm{ft}$ ); however, if an element goes dry and stays dry for several iterations, it can and should be manually disabled to prevent model instability.

The original model was calibrated to the May 19, 2004, flood for which extensive velocity, depth, and water-surface elevation data were collected at several locations throughout the study area (Kelly and Rydlund, 2006). Discharge measurements using hydroacoustic technology were made immediately upstream from the $63 \mathrm{~d}$ Street Bridge and at a location about $540 \mathrm{ft}$ upstream from the mouth of Brush Creek, a currentmeter discharge measurement was made at the upstream face of the lower Blue Parkway Bridge, and water-surface elevations were measured or determined from high-water marks at several locations throughout the study area. These data were used to recalibrate the model of existing conditions. The hydroacoustic discharge measurement made upstream from Brush Creek was at the approximate location of section 10.45 in the HEC-RAS model and the downstream end of the model of existing conditions, so data from this measurement were especially useful in establishing the downstream flow conditions for the 2004 flood.

The 2004 flood had a discharge of approximately 12,300 $\mathrm{ft}^{3} / \mathrm{s}$, which is approximately equivalent to the 2-year recurrence flood, and flow was only bank-full or slightly higher throughout the study area. Whereas this flood was useful in establishing the parameters of materials in the channel, on the banks, and in some of the areas immediately adjacent to the channel, the material properties of vast parts of the flood plains were not able to be calibrated. Therefore, the flood from 
Table 1. Material and hydraulic properties of various land-use coverages resulting from calibration runs of the model of existing conditions and additional land-use coverages used in the model of proposed conditions (modified from Kelly and Rydlund, 2006).

[ft, feet]

\begin{tabular}{|c|c|c|c|c|c|}
\hline \multirow[b]{3}{*}{ Land-use coverage } & \multicolumn{4}{|c|}{ Manning's $n$ roughness coefficient } & \multirow{3}{*}{$\begin{array}{c}\text { Storativity } \\
\text { depth } \\
\text { (ft) }\end{array}$} \\
\hline & \multicolumn{2}{|c|}{ Lower depth } & \multicolumn{2}{|c|}{ Upper depth } & \\
\hline & Manning's $n$ & Depth (ft) & Manning's $n$ & Depth (ft) & \\
\hline \multicolumn{6}{|c|}{ Channel and bank } \\
\hline Unmodified Blue River main channel & 0.037 & 1.5 & 0.020 & 3.0 & 1.0 \\
\hline Timber and brush ${ }^{1}$ & .105 & 2.5 & .075 & 5.0 & 1.5 \\
\hline Thick timber and thick brush ${ }^{2}$ & .120 & 3.0 & .090 & 6.0 & 1.5 \\
\hline Thick grasses with sprouts & .055 & 1.7 & .042 & 3.2 & 1.0 \\
\hline Modified channel with grasses ${ }^{3}$ & .022 & 1.0 & .018 & 2.5 & 1.0 \\
\hline Riprap-lined channel ${ }^{3}$ & .045 & 1.5 & .020 & 3.0 & .5 \\
\hline \multicolumn{6}{|c|}{ Flood plain } \\
\hline Commercial area (junkyard, cars, and machinery) & 0.150 & 5.0 & 0.080 & 7.0 & 1.5 \\
\hline Impervious area & .030 & 1.0 & .025 & 2.0 & .5 \\
\hline Industrial area & .055 & 1.0 & .035 & 2.7 & .7 \\
\hline Railroad embankment & .038 & 1.0 & .032 & 2.0 & 2.7 \\
\hline Residential area with interspersed trees & .055 & 1.5 & .040 & 2.5 & .7 \\
\hline Spoil piles (sand and gravel) ${ }^{4}$ & .032 & 1.0 & .030 & 2.5 & 2.4 \\
\hline \multicolumn{6}{|c|}{ Additional coverages in model of proposed conditions } \\
\hline Baffle block area & 0.250 & 15.4 & 0.150 & 35.0 & 0 \\
\hline Concrete stilling basin & .020 & 1.0 & .015 & 2.5 & 0 \\
\hline Concrete weir & .020 & 1.0 & .015 & 2.5 & 0 \\
\hline
\end{tabular}

May 15, 1990, also was used to supplement the calibration of the model of existing conditions. The 1990 flood had a discharge of approximately $31,800 \mathrm{ft}^{3} / \mathrm{s}$, which is approximately equivalent to the 18-year recurrence flood, and flow occurred on the flood plains on both sides of the channel.

Several caveats are needed in the use of the 1990 flood for calibration. The only data available for this flood were water-surface elevations measured at $63 \mathrm{~d}$ Street and Blue Parkway; water-surface elevations at other locations were not available, and no velocity data were available. Furthermore, Blue River channel modifications up to Brush Creek were not completed until early 2003, so the downstream conditions for the 1990 flood were substantially different from current conditions. Because specific information about the watersurface elevation at the downstream model boundary was not available, the downstream starting water-surface elevation was adjusted until the simulated water-surface elevations at $63 \mathrm{~d}$ Street and Blue Parkway in the model of existing conditions matched the measured elevations from the 1990 flood. The resultant water-surface elevation at the downstream boundary is substantially higher than the elevation that the current channel modifications would warrant based on results at section 10.45 from the HEC-RAS model of the current river conditions, but it is assumed to be the water surface that would have occurred had channel modifications not yet been made. This calibration run is hereinafter referred to as the "model of historic conditions."

Material and hydraulic properties consistent with those used in the original model by Kelly and Rydlund (2006) and other primary sources (Chow, 1959; Barnes, 1967; Arcement and Schneider, 1989) were assigned to the mesh elements in the model of existing conditions (fig. 3). The material properties were then adjusted to match the observed high-water marks from both the 1990 and the 2004 floods. The adjusted material properties are consistent with, but slightly different from, those obtained by Kelly and Rydlund (2006) (table 1). Measured and simulated water-surface elevations for the two floods are shown in figure 4 and table 2, and measured and simulated cross-sectional area and area-weighted average velocity at three measurement locations for the 2004 flood are shown in table 3 . The simulated water-surface elevation at the downstream model boundary for the 2004 flood was set 0.2 $\mathrm{ft}$ lower than the water-surface elevation measured at section 10.45 during that flood to improve the match at marks further upstream (table 2) and to better match measured cross-sectional area and velocity at section 10.45 (table 3 ). 


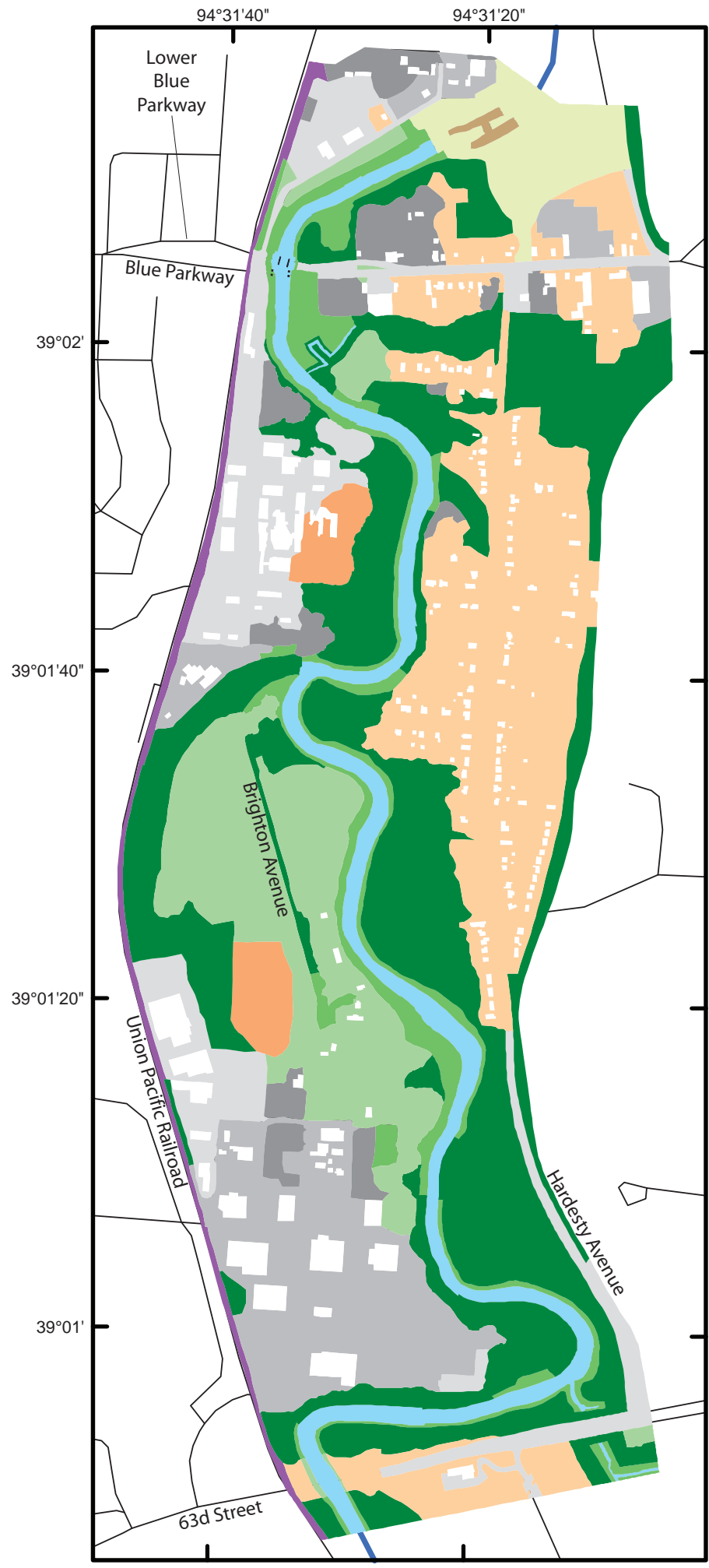

\section{EXPLANATION}

Land use - White areas within the study area indicate buildings or other structures

Area of no flow

Unmodified Blue River main channel (sand and gravel)

Timber and brush

Thick timber and thick brush

Thick grasses with sprouts

Modified channel with grasses

Riprap-lined channel

Commercial area (junkyard, cars, and machinery)

Impervious area

Industrial area

Railroad embankment

Residential area with interspersed trees

Spoil piles (sand and gravel)

- Roads/railroads

Blue River channel beyond study area

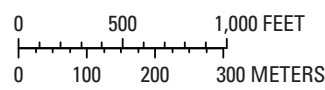

Base from U.S. Geological Survey digital data, 1:24,000, 1996

Universal Transverse Mercator projection, Zone 15

Horizontal coordinate information referenced to the North American

Datum of 1983 (NAD 83)

Figure 3. Land-use coverages used in the model of existing conditions on the Blue River. 


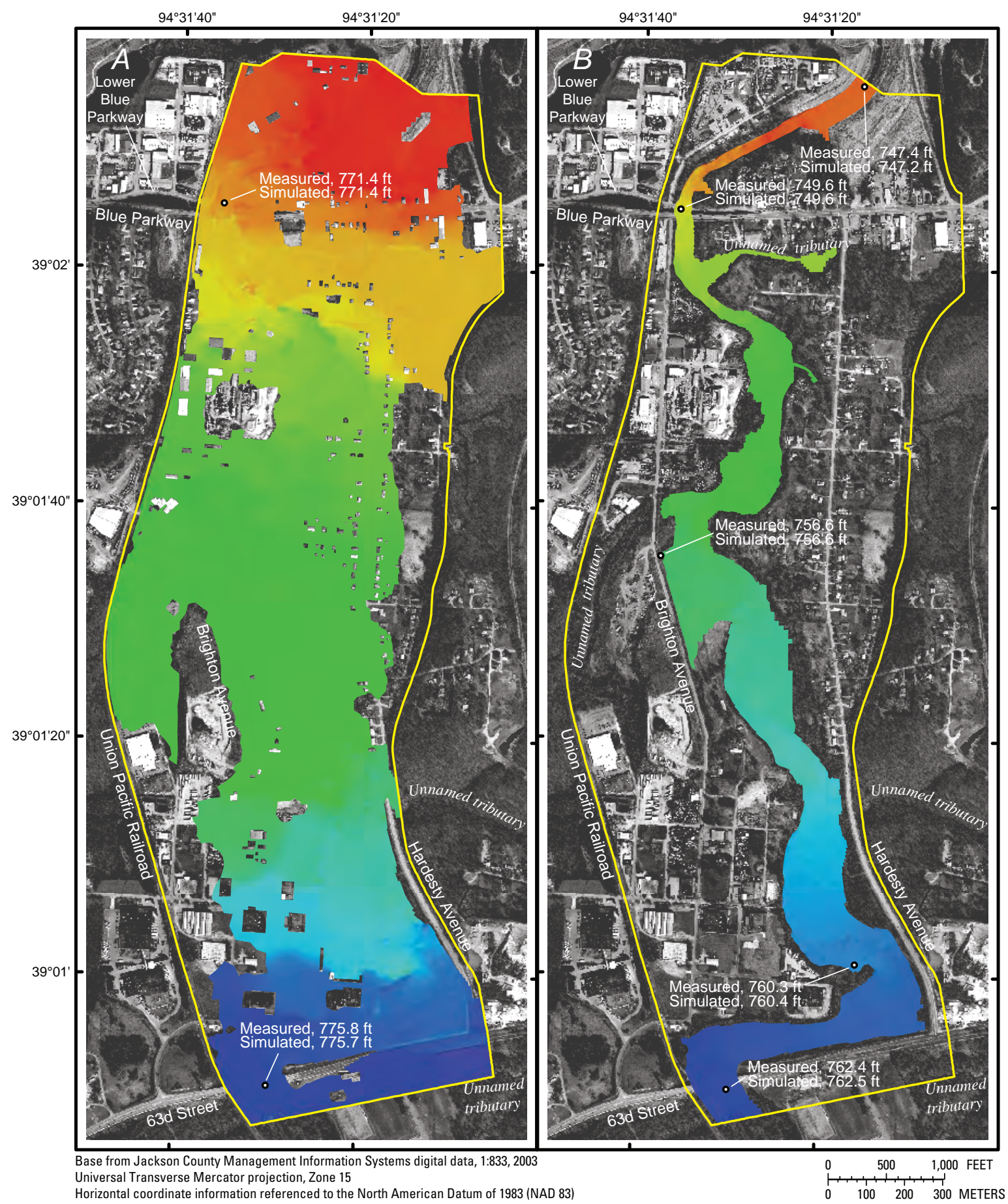

EXPLANATION

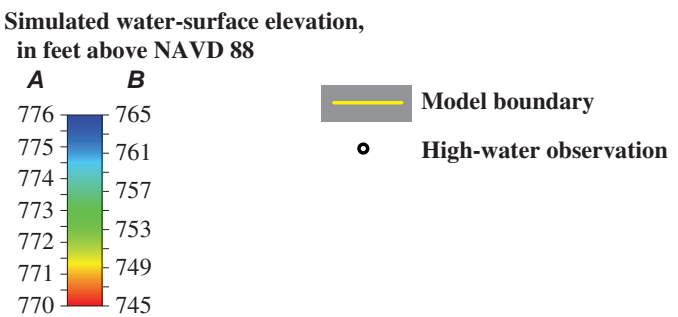

Figure 4. Measured and simulated water-surface elevations from the model of existing conditions for the floods of (A) May 15, 1990, and (B) May 19, 2004, on the Blue River. 
Table 2. Measured and simulated water-surface elevations for calibration floods of May 15, 1990, and May 19, 2004.

[ft $\mathrm{ft}^{3} \mathrm{~s}$, cubic feet per second; ft, feet; HEC-RAS, Hydrologic Engineering Center's River Analysis System; --, not determined/not applicable]

\begin{tabular}{|c|c|c|c|c|c|c|}
\hline \multirow[b]{2}{*}{ Location } & \multicolumn{3}{|c|}{$\begin{array}{c}\text { May 15, 1990, flood } \\
\left(31,800 \mathrm{ft}^{3} / \mathrm{s}\right)\end{array}$} & \multicolumn{3}{|c|}{$\begin{array}{c}\text { May 19, 2004, flood } \\
\left(12,300 \mathrm{ft}^{3} / \mathrm{s}\right) \\
\end{array}$} \\
\hline & $\begin{array}{l}\text { Measured } \\
\text { water- } \\
\text { surface } \\
\text { elevation } \\
\text { (ft) }\end{array}$ & $\begin{array}{l}\text { Simulated } \\
\text { water- } \\
\text { surface } \\
\text { elevation } \\
\text { (ft) }\end{array}$ & $\begin{array}{l}\text { Simulated } \\
\text { minus } \\
\text { measured } \\
(\mathrm{ft})\end{array}$ & $\begin{array}{l}\text { Measured } \\
\text { water- } \\
\text { surface } \\
\text { elevation } \\
\text { (ft) }\end{array}$ & $\begin{array}{l}\text { Simulated } \\
\text { water- } \\
\text { surface } \\
\text { elevation } \\
\text { (ft) }\end{array}$ & $\begin{array}{l}\text { Simulated } \\
\text { minus } \\
\text { measured } \\
(\mathrm{ft})\end{array}$ \\
\hline $\begin{array}{l}\text { Downstream limit of model of existing } \\
\text { conditions (section } 10.45 \text { in HEC-RAS } \\
\text { model) }\end{array}$ & -- & 1770.6 & -- & 747.4 & 747.2 & -0.2 \\
\hline $\begin{array}{l}\text { Upstream face of lower Blue Parkway } \\
\text { Bridge }\end{array}$ & 771.4 & 771.4 & 0 & 749.6 & 749.6 & 0 \\
\hline Brighton Avenue toe of embankment & -- & -- & -- & 756.6 & 756.6 & 0 \\
\hline Byram's Ford & -- & -- & -- & 760.3 & 760.4 & +.1 \\
\hline
\end{tabular}

${ }^{1}$ The water-surface elevation that is assumed to have existed if the Blue River channel had not been modified to Brush Creek.

Table 3. Measured and simulated cross-sectional area and area-weighted average velocity at discharge measurement locations for the calibration flood of May 19, 2004.

[ft² , square feet; ft/s, feet per second; HEC-RAS, Hydrologic Engineering Center's River Analysis System]

\begin{tabular}{|c|c|c|c|c|}
\hline Location & $\begin{array}{l}\text { Measured cross- } \\
\text { sectional area } \\
\left(\mathrm{ft}^{2}\right)\end{array}$ & $\begin{array}{l}\text { Simulated cross- } \\
\text { sectional area } \\
\left(\mathrm{ft}^{2}\right)\end{array}$ & $\begin{array}{l}\text { Measured average } \\
\text { velocity } \\
\text { (ft/s) }\end{array}$ & $\begin{array}{l}\text { Simulated average } \\
\text { velocity } \\
\text { (ft/s) }\end{array}$ \\
\hline $\begin{array}{l}\text { Downstream limit of model of existing } \\
\text { conditions (section } 10.45 \text { in HEC-RAS } \\
\text { model) }\end{array}$ & $2,901.8$ & $2,915.7$ & 4.30 & 4.20 \\
\hline $\begin{array}{l}\text { Upstream face of lower Blue Parkway } \\
\text { Bridge }\end{array}$ & $1,883.0$ & $2,049.4$ & 6.85 & 5.90 \\
\hline Upstream face of 63d Street Bridge & ${ }^{1} 4,230.0$ & $4,268.0$ & $2.88^{1}$ & 2.87 \\
\hline
\end{tabular}

${ }^{1}$ Measurement made immediately upstream from 63d Street Bridge.

\section{Simulation of Flood Flows}

Once the model of existing conditions had been calibrated to the two floods, simulations of the 30-, 50-, and 100 -year floods were conducted. Discharges and associated water-surface elevations for various recurrence intervals at section 10.45 in the HEC-RAS model are shown in table 4. The discharges and water-surface elevations from the HECRAS model for the 30-, 50-, and 100-year floods were used as boundary conditions in the simulations with the model of existing conditions.

The downstream water-surface elevation for the 100year flood from the HEC-RAS model was less than that for the model of historic conditions (tables 2 and 4). Therefore, the simulation of the 100-year flood in the model of existing conditions was started with the 100-year discharge of 53,700 $\mathrm{ft}^{3} / \mathrm{s}$ as the upstream boundary and the results from the model of historic conditions as the hotstart. Elements in the upstream part of the study area that had been disabled for the simulation with the model of historic conditions were reenabled to ensure that all elements that could possibly be wet were active.

The simulation of the 100-year flood in the model of existing conditions was spun down until the desired downstream water-surface elevation was reached (table 4). Simulation of the 50-year flood was started with the 50-year discharge of $44,500 \mathrm{ft}^{3} / \mathrm{s}$ as the upstream boundary and the results from the 100-year flood simulation as the hotstart. The 50-year flood simulation was spun down until the desired downstream water-surface elevation was reached (table 4), and the simulation of the 30-year flood was started with the 30 -year discharge of $35,000 \mathrm{ft}^{3} / \mathrm{s}$ as the upstream boundary and the results from the 50-year flood simulation as the hotstart. The model of existing conditions was saved into a new directory on the computer for each flood simulation so that the model results for each flood were available for refinement and comparison. In this way, it was possible to rapidly spin down to simulation results that were within $0.1 \mathrm{ft}$ of the final downstream water-surface elevation for each flood. Each 
Table 4. Discharge and water-surface elevations associated with various recurrence-interval floods from section 10.45 in the Hydrologic Engineering Center's River Analysis System (HEC-RAS) model.

$\left[\mathrm{ft}^{3} / \mathrm{s}\right.$, cubic feet per second; $\mathrm{ft}$, feet]

\begin{tabular}{lcc}
\hline $\begin{array}{c}\text { Recurrence } \\
\text { interval }\end{array}$ & $\begin{array}{c}\text { Discharge } \\
\left(\mathbf{f t}^{3} / \mathbf{s}\right)\end{array}$ & $\begin{array}{c}\text { Water-surface } \\
\text { elevation } \\
\text { (ft) }\end{array}$ \\
\hline 2-year & 13,200 & 744.75 \\
5-year & 20,300 & 749.09 \\
10-year & 26,320 & 752.47 \\
18-year ${ }^{1,2}$ & 131,800 & 1754.75 \\
20-year & 34,000 & 755.67 \\
30-year & & 3756.19 \\
50-year & 35,000 & 761.17 \\
100-year & 44,500 & 764.07 \\
200-year & 53,700 & 765.57 \\
500-year & 62,000 & 767.89 \\
\hline
\end{tabular}

${ }^{1}$ This represents the flood of May 15, 1990. Recurrence interval and water-surface elevation interpolated from 10- and 20-year data.

${ }^{2}$ Information from this recurrence interval used for boundary conditions in two-dimensional models.

${ }^{3}$ Interpolated from 20- and 50-year data.

flood simulation was then refined by setting the convergence parameters to extremely small values so that the results at any individual node in the model essentially did not change from one iteration to the next (less than 0.01 feet squared per second $\left(\mathrm{ft}^{2} / \mathrm{s}\right)$ change in unit discharge and less than $0.005 \mathrm{ft}$ change in water-surface elevation). At this point, the simulation of each flood was considered to be final. The simulated water-surface elevations for the entire study area from the model of existing conditions are shown in figure 5 .

The discharge from the May 15, 1990, flood also was simulated in the model of existing conditions to examine the effects of the current modifications to the channel. A downstream water-surface elevation for that flood was interpolated from the results available at section 10.45 in the HEC-RAS model (table 4). This simulation was performed using the same procedure as that which was used in the 30-, 50-, and 100 -year simulations, and is hereinafter referred to as the "model of existing conditions (1990 flood)."

\section{Limitations of Model of Existing Conditions}

As discussed in the recalibration section, the 1990 flood had a discharge of $31,800 \mathrm{ft}^{3} / \mathrm{s}$, which is approximately equivalent to the 18-year recurrence flood; however, the water-surface elevations in the downstream part of the study area for the
1990 flood simulation from the model of historic conditions (fig. $4 A$ ) were higher than those obtained for the 100-year flood simulation in the model of existing conditions (fig. 5C). This difference in downstream water-surface elevations is directly attributable to the difference in historical downstream channel conditions (those during the 1990 flood) and the existing downstream channel conditions.

At the time of the May 15, 1990, flood, modifications on the Blue River had been completed up to a location somewhere between U.S. Highway 24 and 12th Street (fig. 1), and most of the Blue River channel downstream from 63d Street was still unmodified (U.S. Army Corps of Engineers, 2004). The unmodified channel was smaller in cross-sectional area than was the modified channel, had numerous bends, and generally had a thick, brushy riparian corridor (Richard Huizinga, U.S. Geological Survey, data on file, 1998; John Holm, U.S. Army Corps of Engineers, oral commun., 2006), all of which contribute to higher water-surface elevations during floods. Conversely, the modified channel has increased cross-sectional area, smooth bends, and a more limited riparian corridor, resulting in increased conveyance and lower water-surface elevations during floods.

Most of the current channel and flood plain characteristics are similar to those that existed during the 1990 flood, as well as to those that existed in 1983 before channel modifications began; however, boundary conditions have changed at the downstream end of the study area as the channel modifications have been completed. Therefore, the "existing conditions" of flow in the study area as shown by the model of existing conditions are substantially different from the conditions that existed 16 years ago during the 1990 flood, or from the conditions that existed before modifications to the Blue River began in 1983.

\section{Model of Proposed Conditions}

While the model of existing conditions was being run to simulate the 30-, 50-, and 100-year floods, a model of the study area with the proposed channel modifications and GCS was developed. This model of proposed conditions was used to provide results for the study area with all of the proposed channel modifications in place.

\section{Modification of Model of Existing Conditions for Proposed Channel Modifications}

The model of existing conditions was altered to incorporate the proposed modifications of the Blue River channel. These modifications consist of (1) a realignment of the channel centerline to remove or lessen the severity of meander bends, (2) channel widening, (3) improvement of tributary junctions, and (4) addition of the GCS and related structures (fig. 6). The prototype design for the GCS from Cooper (1996) and the proposed channel modifications were hard-coded into the finite element network. An orthographic projection of the 

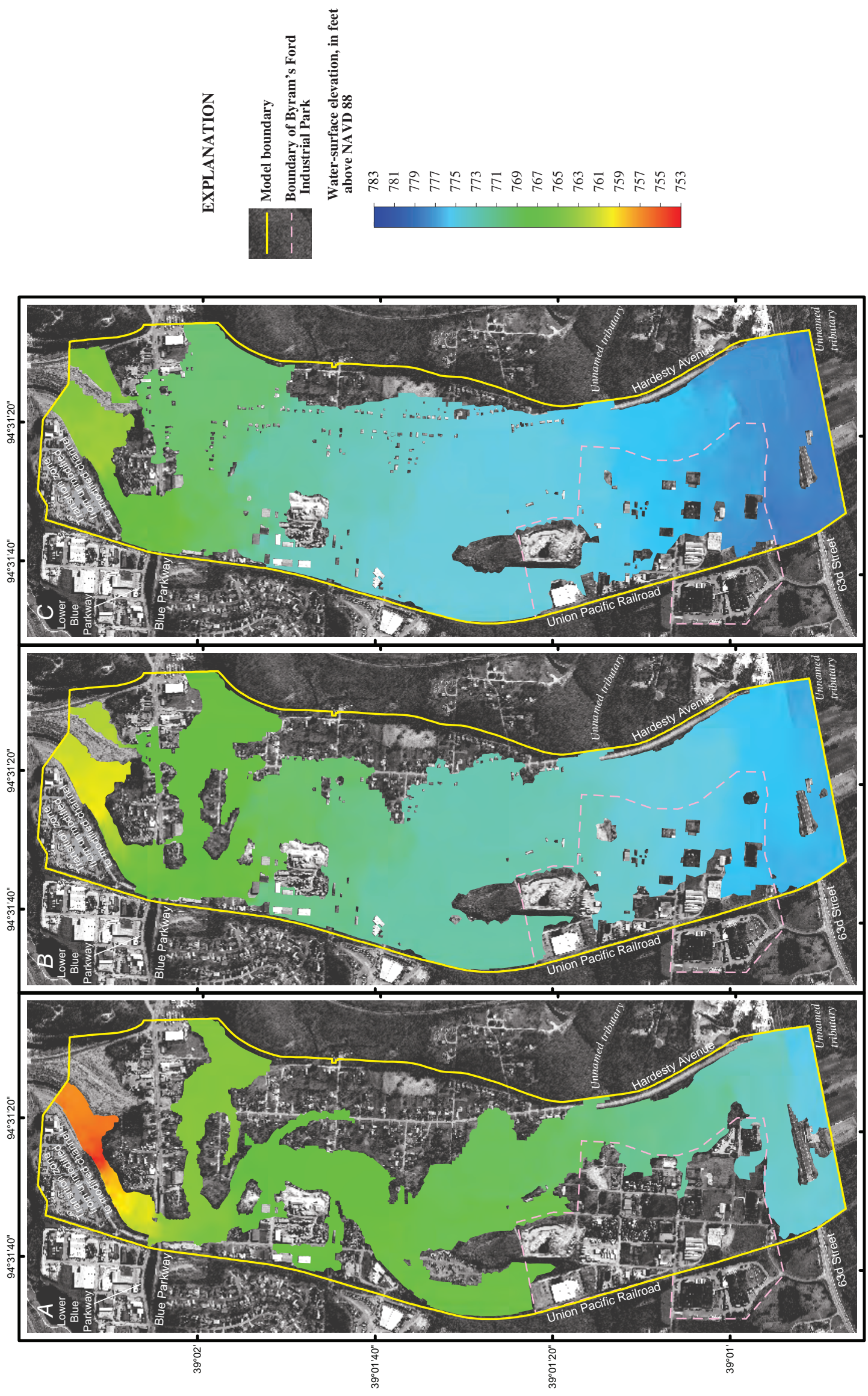

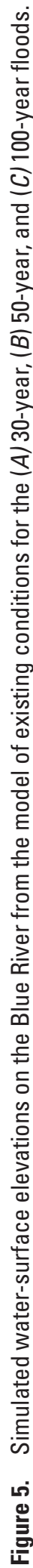




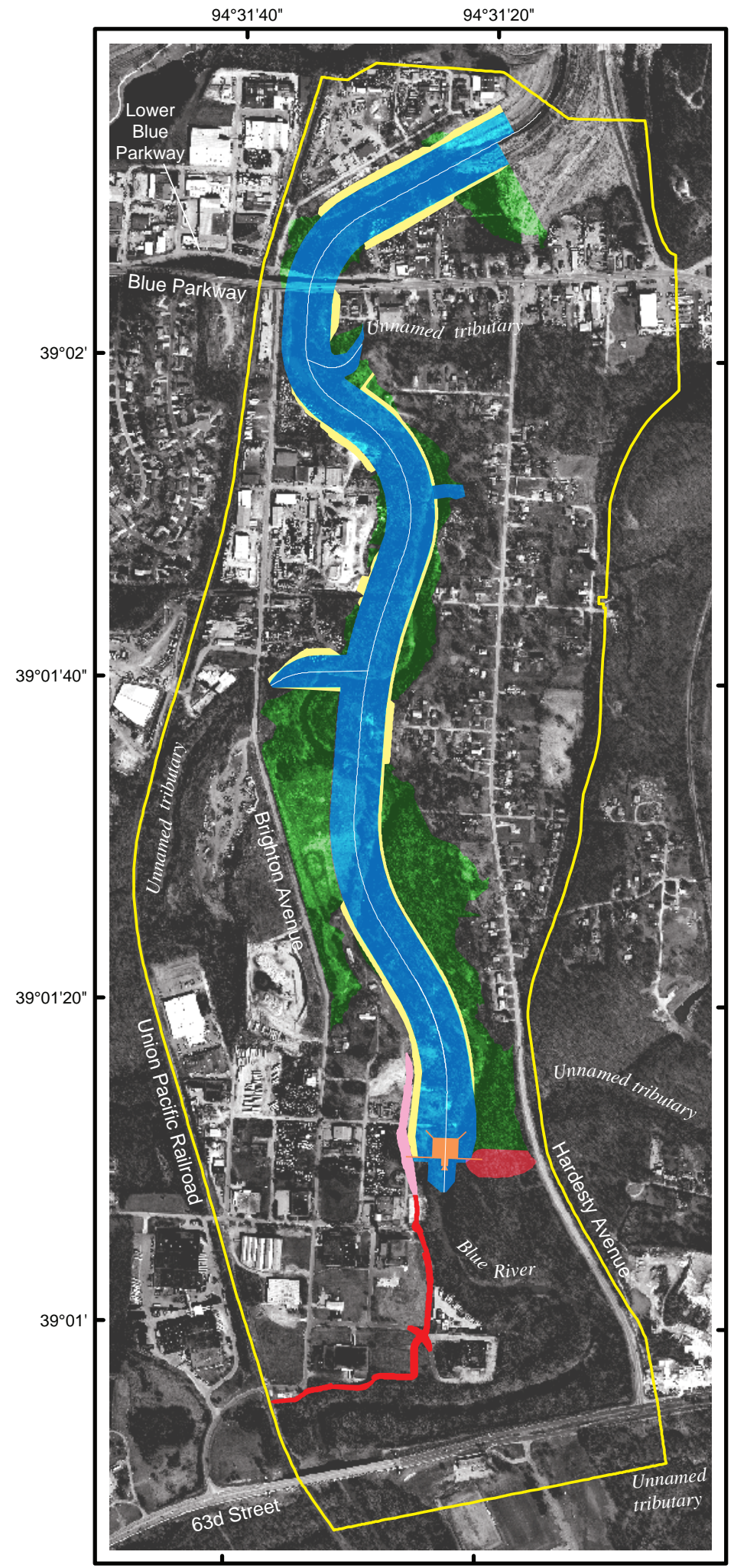

\section{EXPLANATION}

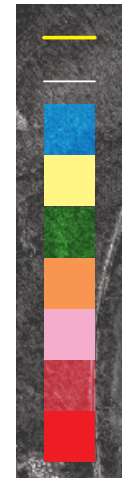

Model boundary

Control (channel center) lines

Main and tributary channel modifications

Upper bank work

Fill areas

Grade control structure

Left trail levee

Right tie-back levee

Spoil berm

Base from Jackson County Management Information Systems digital data, 1:833, 2003

Universal Transverse Mercator projection, Zone 15

Horizontal coordinate information referenced to the North American Datum of 1983 (NAD 83)

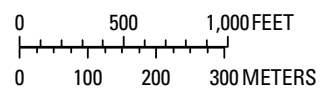

Figure 6. Proposed channel modifications on the Blue River. 
GCS (the weir, concrete stilling basin, and tie-back walls) and levees are shown in figure 7.

\section{Prototype Design of the Grade Control Structure}

The recommended prototype design for the GCS was the type 25 weir, type 2 debris deflector, and the type 1 concrete stilling basin (Cooper, 1996). The type 25 weir consists of a three-stage weir design with a modified drop inlet. The first stage of the weir has a crest elevation of $732.28 \mathrm{ft}$ (the approach channel elevation) and a length of $10 \mathrm{ft}$. This stage of the weir is also called the "low-flow slot" (fig. 7). The middle stage of the weir is the drop inlet and has a crest elevation of $750.28 \mathrm{ft}$ and a length of $76 \mathrm{ft}$ ("drop inlet" in fig. 7). Walls sloping at 45 degrees upward from the back of the drop inlet provide transition from the middle to the upper stage of the weir. The upper stage of the weir has a crest elevation of $770.28 \mathrm{ft}$ and a length of $124 \mathrm{ft}$ ("upper weir" in fig. 7).

The type 2 debris deflector consists of two walls sloping at a ratio of 1 to 2 (vertical to horizontal) and flared at 30 degrees to flow. These walls extend upstream from the drop inlet on either side of the low-flow slot, providing a way for debris to pass through the relatively narrow slot ("debris deflector" in fig. 7).

The type 1 concrete stilling basin is downstream from the upper stage of the weir wall, is $160 \mathrm{ft}$ wide and $127.5 \mathrm{ft}$ long, and has a floor elevation of $725.88 \mathrm{ft}$. Energy dissipation in the basin is accomplished by means of baffle blocks and an end sill. Ten baffle blocks, each $8 \mathrm{ft}$ square and 15.4 $\mathrm{ft}$ tall and spaced $8 \mathrm{ft}$ apart, are located $32.5 \mathrm{ft}$ upstream from the downstream edge of the basin. The end sill (not visible in fig. 7) is perpendicular to flow across the downstream edge of the basin, at an elevation of $732.28 \mathrm{ft}$. The walls on either side of the basin have a top elevation of $782.28 \mathrm{ft}$, with outflow wingwalls flared at 45 degrees to flow and sloping downward at 45 degrees. Low-flow training walls (not visible in fig. 7) extend from the drop inlet to the end sill, parallel to flow, and are $8 \mathrm{ft}$ tall.

Tie-back walls and levees on either side of the channel divert flow into the GCS. The tie-back walls ("tie-back walls" in fig. 7) extend on either side of the upper stage of the weir and upstream end of the concrete stilling basin and have a top elevation of $782.28 \mathrm{ft}$. The levee on the left ("left trail levee"

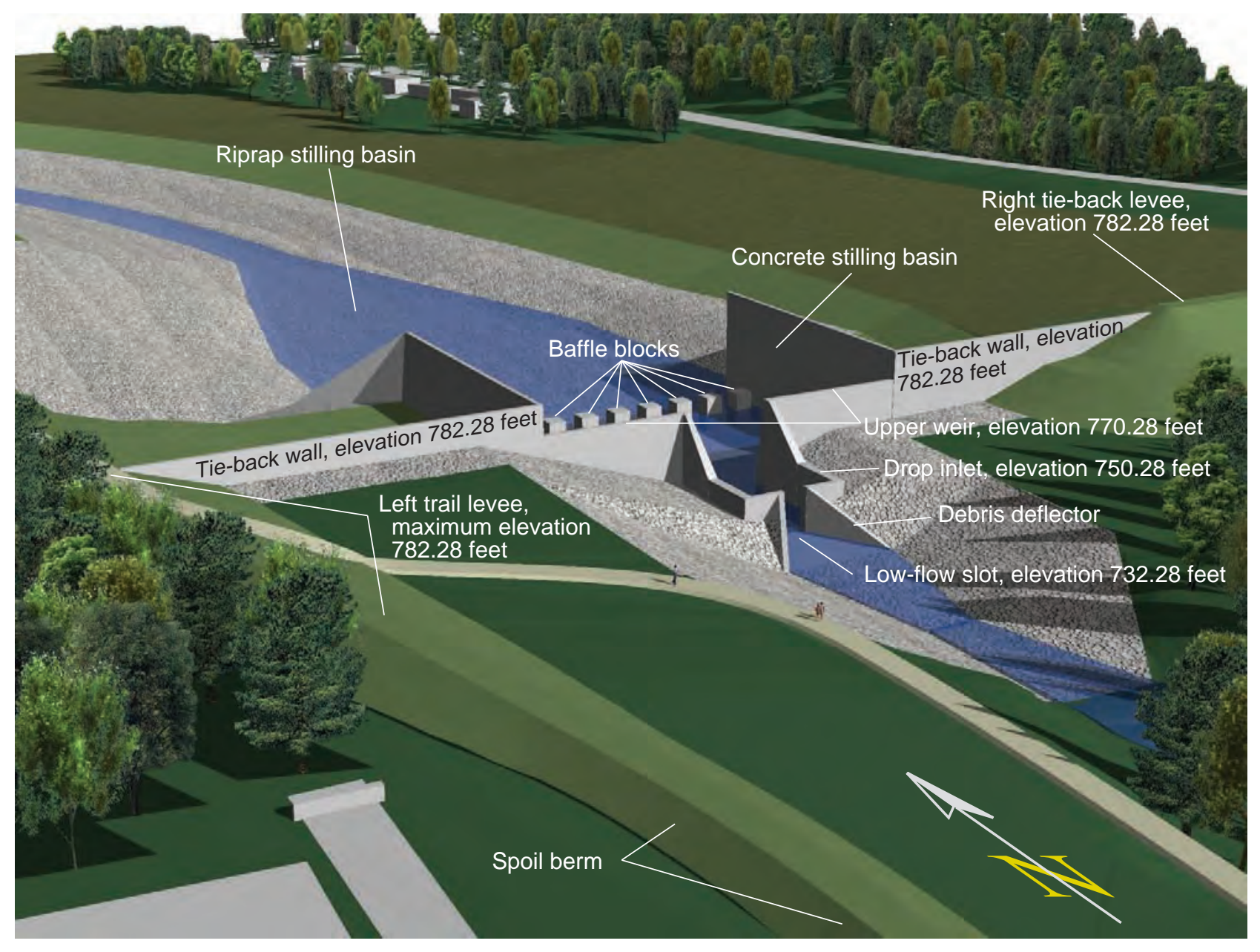

Figure 7. Orthographic projection of the proposed grade control structure and levees on the Blue River (generated from preliminary plans, John Holm, U.S. Army Corps of Engineers, written commun., 2004). 
in fig. 7) runs essentially parallel to flow, beginning about 200 $\mathrm{ft}$ upstream from the GCS and extending about $650 \mathrm{ft}$ downstream, with a maximum elevation of $782.28 \mathrm{ft}$. The levee on the right ("right tie-back levee" in fig. 7) extends from the right side tie-back wall to Hardesty Avenue, perpendicular to the direction of flow, and has a constant top elevation of $782.28 \mathrm{ft}$.

\section{Modifications to Prototype Features for Use in Two- Dimensional Model}

Because of limitations of FESWMS, modifications were required to create the mesh elements in and around the GCS to adequately represent its unique features and yet maintain mesh quality. A single node cannot have two elevations in FESWMS; therefore, vertical walls or other vertical features were impossible to code except as a model boundary. The tie-back walls and side walls of the concrete stilling basin were not expected to be overtopped by the 100-year flood, so these walls were coded as model boundaries; however, flow was expected over the vertical and nearly vertical walls of the upper weir, drop inlet, upstream debris deflectors, end sill, and low-flow training walls. The weir module in FESWMS was examined to model the weir and drop inlet, but this module mainly was designed to model one-dimensional flow over roadway embankments (Froehlich, 2002). The configuration of the three-stage weir and drop inlet was anticipated to lead to multidimensional flow that would compromise the assumption of one-dimensional weir flow.

Ultimately, the vertical or nearly vertical walls of the GCS that were not able to be coded as model boundaries had to be constructed with elements that had some finite amount of slope (fig. 8). The slope was made as near to vertical as possible while maintaining model integrity, mesh quality, and numerical and computational stability. The slope generally was dictated by the distance between nodes at the top and bottom of the wall- the smaller the distance between these nodes, the steeper the slope. The distance between the nodes

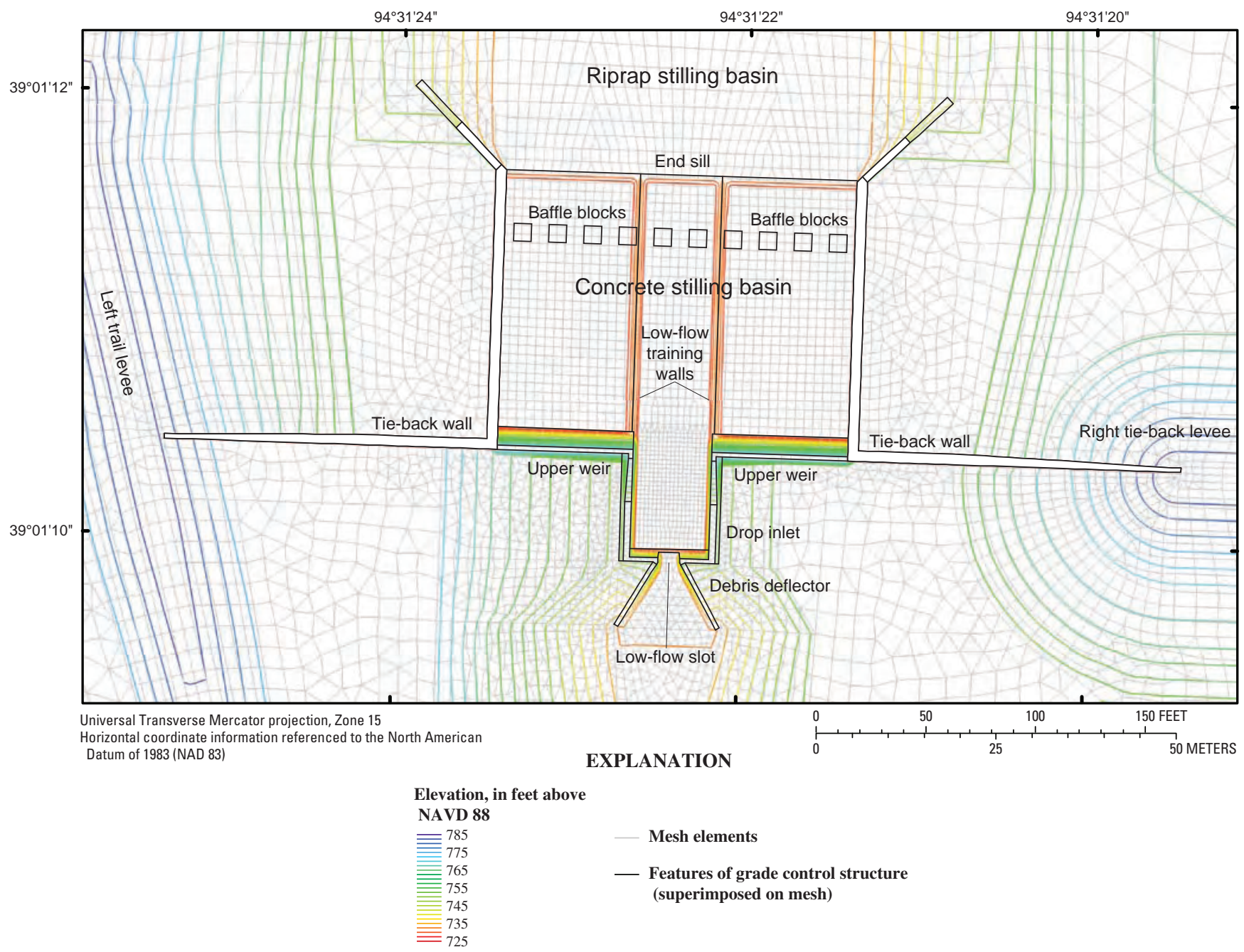

Figure 8. Finite element mesh with contours in the vicinity of the proposed grade control structure depicting nearly vertical wall construction. 
was controlled by element size and aspect ratio in relation to the direction of flow. Element size generally is controlled by overall model size and computational requirements-smaller element size requires greater element density, which requires longer computation time. Aspect ratio of elements was critical at walls that were perpendicular to flow (such as the weir, the drop inlet, and the end sill). To have a mesh with nearly vertical walls that was numerically stable and would run in a reasonable amount of time, elements that were at least 1 square foot $\left(\mathrm{ft}^{2}\right)$ in area were necessary, and elements that were nearly perfectly square near walls perpendicular to flow often were necessary.

The baffle blocks in the concrete stilling basin were another feature in the GCS with vertical faces. The pier module was used to provide the best physical representation of the blocks in the model, with each block being coded as an individual pier. The length of each block ( $8 \mathrm{ft}$ ) was coded as the pier length, but because a height could not be assigned in the pier module, each block was assumed to extend through the full depth of the water column. Therefore, for depths of flow greater than the height of the blocks $(15.4 \mathrm{ft})$, the width of the blocks was reduced to maintain the correct cross-sectional area of blocked flow in the stilling basin. The amount of reduction was based on the ratio of the height of the blocks to the approximate depth of flow as measured near the center of the stilling basin (table 5). The area around the baffle blocks extending to the end sill of the concrete stilling basin was assigned a variable-with-depth roughness value that represented the effects of the blocks with increasing depth (table 1).

\section{Channel Modifications}

The GCS and a large riprap stilling basin downstream from the concrete stilling basin provide the transition of flow from the natural channel to the modified channel (fig. 8). The proposed modified channel has a regular cross section with banks composed of various steps (fig. 9). The uppermost step ("upper bank work" in figs. 6 and 9) has variable width in many locations because this step will be used to tie into the existing flood plain, and the slope of the upper step is maintained until the desired local elevation is reached. The various tributaries that connect with the Blue River will have improved junctions, and several drains into the channel will be protected with riprap to prevent erosion of the banks.

As a result of the channel realignment, several large areas will need to be filled where the channel currently exists (fig. $6)$. These fill areas were designed to slope gently toward the new channel. The large fill area downstream and to the right of the GCS will be planted with trees, and other fill areas will be seeded for grass (Helena Mosser, U.S. Army Corps of Engineers, written commun., 2006).

As part of the proposed channel changes, the lower Blue Parkway Bridge will be removed, and the existing Blue Parkway Bridge will be reoriented and widened (fig. 2). The piers for the reoriented and widened Blue Parkway Bridge were hard-coded as elements in the mesh of the model of proposed conditions because they will have an effect on flow in the modified channel. Position, orientation, and dimensions of each pier were taken from bridge plans to accurately position and size the piers (City of Kansas City, Department of Public Works, 2004), and the elements within each pier location were manually disabled to force flow around the piers.

To provide additional flood protection to the Byram's Ford Industrial Park, a spoil berm is proposed along the left bank. This berm will be made from fill taken from the channel during modifications and will extend upstream from the left trail levee along the left side of the GCS upstream along the left bank and tie into the railroad embankment immediately downstream from 63d Street (fig. 6).

Material and hydraulic properties developed in the model of existing conditions were left as they were in that model, and new mesh elements in areas of channel modification were assigned values consistent with the model of existing conditions based on the proposed land use in the model of proposed conditions (fig. 10; table 1). Most of the modified channel was assigned the "modified channel with grasses" material properties, and areas that will be covered with riprap were assigned the "riprap-lined channel" material properties. The large fill area downstream and to the right of the GCS will be planted with trees and was assigned the "timber and brush" material properties. Other fill areas will be seeded for grass but will not receive routine mowing and were assigned the "thick grasses

Table 5. Modification of baffle block width in the pier module based on depth of flow in the concrete stilling basin.

$\left[\mathrm{ft}^{3} / \mathrm{s}\right.$, cubic feet per second; ft, feet]

\begin{tabular}{lcccc}
\hline Modeled flood & $\begin{array}{c}\text { Discharge } \\
(\mathbf{f t} / \mathbf{s})\end{array}$ & $\begin{array}{c}\text { Approximate depth } \\
\text { of flow near center of } \\
\text { concrete stilling basin } \\
(\mathbf{f t})\end{array}$ & $\begin{array}{c}\text { Ratio of baffle } \\
\text { block height } \\
(\mathbf{1 5 . 4} \mathbf{f t}) \text { to depth } \\
\text { of flow }\end{array}$ & $\begin{array}{c}\text { Width of baffle } \\
\text { block assigned } \\
\text { in pier module } \\
\text { (ft) }\end{array}$ \\
\hline 30-year & 35,000 & 30.5 & 0.505 & 4.04 \\
50-year & 44,500 & 36.5 & .422 & 3.38 \\
100-year & 53,700 & 40.0 & .385 & 3.08 \\
1990 flood & 31,800 & 29.0 & .531 & 4.25 \\
\hline
\end{tabular}




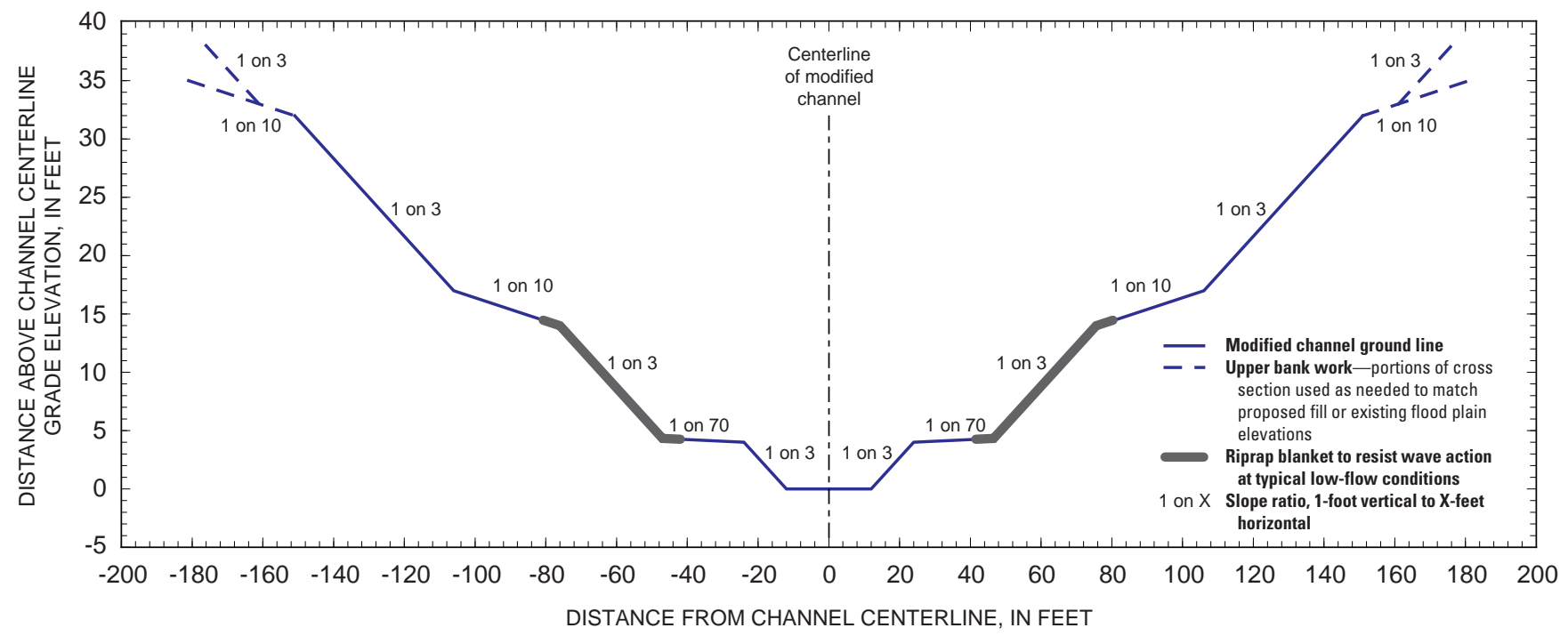

Figure 9. Cross section of the Blue River channel after proposed modifications.

with sprouts" material properties. The left trail levee, right tie-back levee, and spoil berm will be seeded for grass and will receive routine mowing (Helena Mosser, written commun., 2006); therefore, they were assigned the "industrial area" material properties.

Three new land-use coverages pertaining specifically to the GCS were used in the model of proposed conditions: the "baffle block area," the "concrete stilling basin," and the "concrete weir" coverages (table 1; fig. 10). These coverages were assigned material properties based on Chow (1959) and were originally assigned a value of kinematic eddy viscosity that would promote model stability $\left(150 \mathrm{ft}^{2} / \mathrm{s}\right)$. After spinning the model down to the desired boundary conditions, the eddy viscosity was adjusted to a more appropriate value (the baffle block area was adjusted to $50 \mathrm{ft}^{2} / \mathrm{s}$ and the concrete stilling basin and concrete weir were adjusted to $10 \mathrm{ft}^{2} / \mathrm{s}$ ) consistent with guidelines in Froehlich (2002).

After inclusion of the proposed channel modifications, the finite element mesh for the model of proposed conditions consisted of 56,533 elements. Each element had a node at each corner and at the midpoint of each side, which created a total of 143,881 nodes.

\section{Simulation of Flood Flows}

As with the model of existing conditions, simulations of the 30-, 50-, and 100-year recurrence floods were conducted with the model of proposed conditions. The discharges and associated water-surface elevations from the HEC-RAS model for the 30-, 50-, and 100-year floods shown in table 4 were used as boundary conditions in the simulations with the model of proposed conditions.

The simulation of the 100-year flood in the model of proposed conditions had to be started with a water-surface elevation that was higher than the highest ground elevation in the mesh to ensure that all of the elements and nodes were wet. Therefore, the upstream boundary was set to the 100-year discharge of $53,700 \mathrm{ft}^{3} / \mathrm{s}$, and the downstream water-surface elevation initially was set to $810.00 \mathrm{ft}$. The simulation of the 100 -year flood in the model of proposed conditions was spun down until the desired downstream water-surface elevation was reached (table 4). As with the model of existing conditions, the model of proposed conditions was saved into a new directory on the computer for the 30-, 50-, and 100-year flood simulations so that the model results for each flood were available for refinement and comparison. Each flood simulation was refined by lowering the kinematic eddy viscosities in the GCS and setting the convergence parameters to extremely small values. When the results at any individual node in the model essentially did not change from one iteration to the next (less than $0.01 \mathrm{ft}^{2} / \mathrm{s}$ change in unit discharge and less than $0.005 \mathrm{ft}$ change in water-surface elevation), the simulation of each flood was considered to be final. The simulated watersurface elevations for the entire study area from the model of proposed conditions are shown in figure 11.

The discharge from the May 15, 1990, flood also was simulated in the model of proposed conditions to examine the effects of the proposed modifications on that flood. A downstream water-surface elevation for that flood was interpolated from the results available at section 10.45 in the HEC-RAS model (table 4). This simulation was performed using the same procedure as that which was used in the 30-, 50-, and 100-year simulations.

\section{Limitations of Model of Proposed Conditions}

The model of proposed conditions could not be calibrated. Many of the material and hydraulic properties were not changed from one model to the other, providing consistency between the calibrated model of existing conditions and the 


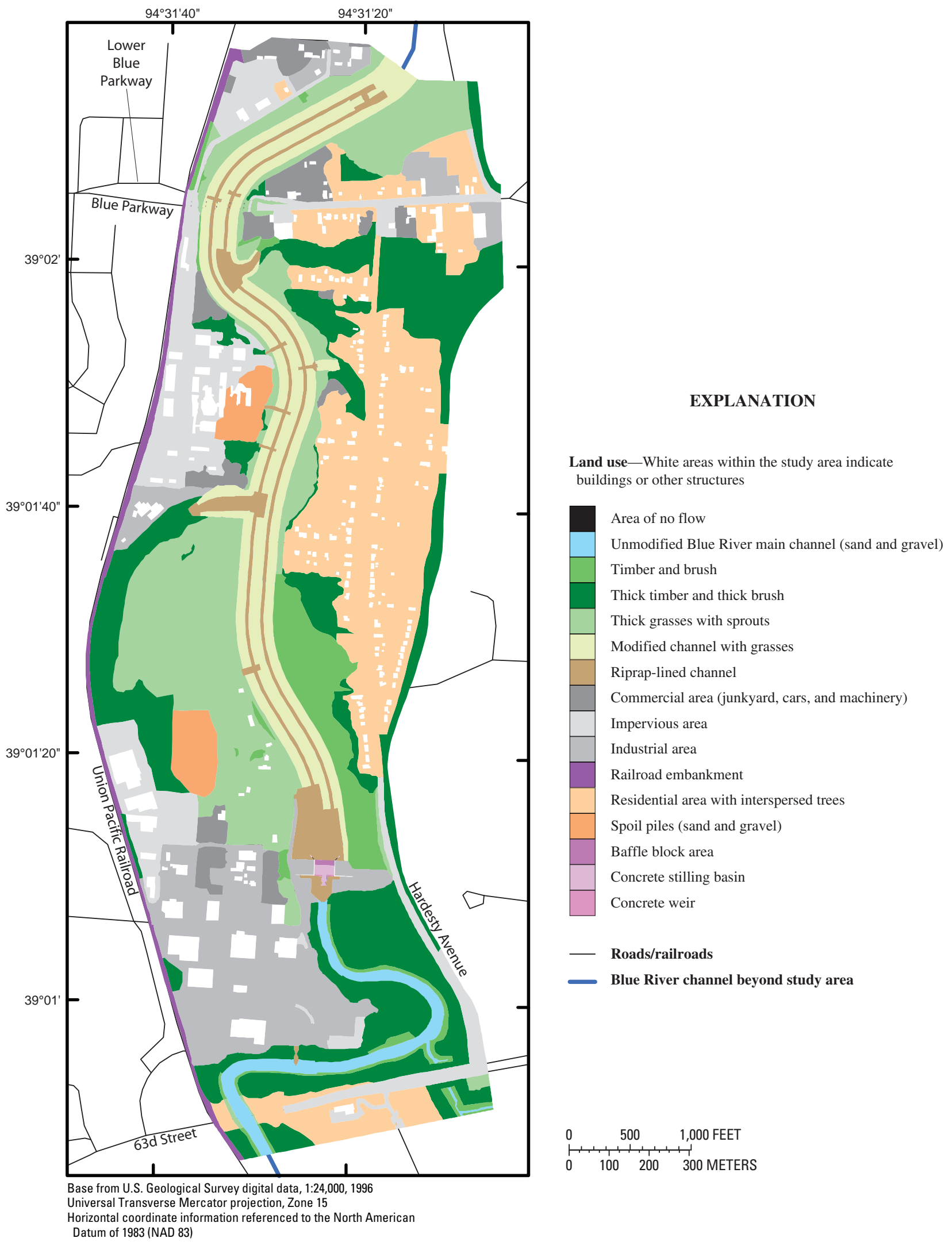

Figure 10. Land-use coverages used in the model of proposed conditions on the Blue River. 

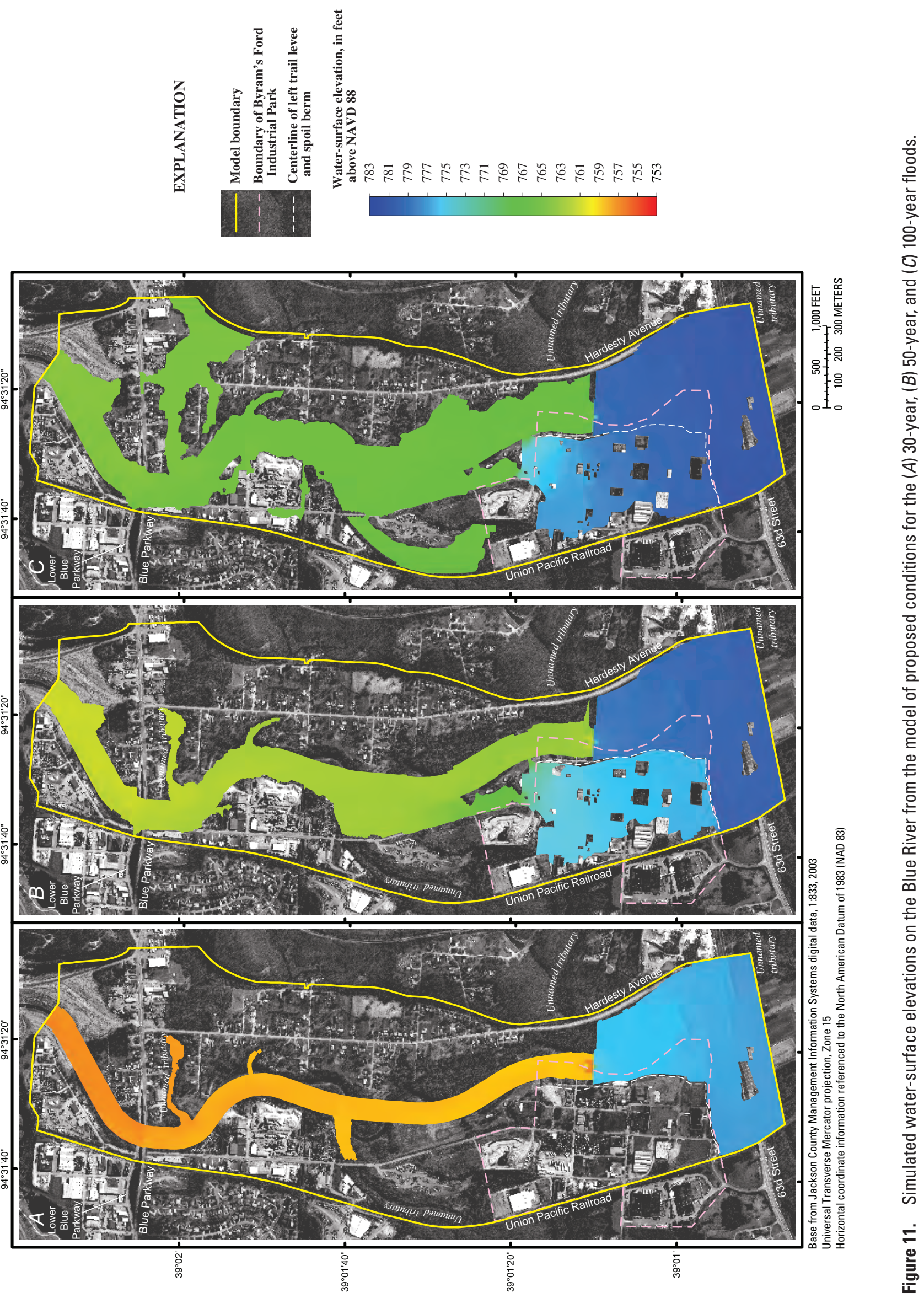
uncalibrated model of proposed conditions. Nevertheless, the modified channel and GCS were key features in the model of proposed conditions that were changed from one model to the other. Although the modified channel was assigned material and hydraulic properties that were consistent with similar features in the model of existing conditions ("modified channel with grasses" and "riprap-lined channel"), these features were limited to the downstream part of the study area in the model of existing conditions. In the model of proposed conditions, these features are much more extensive; therefore, the effect of a potential error in the material and hydraulic properties of these features would be more substantial in this model than in the model of existing conditions. Furthermore, the material and hydraulic properties assigned to elements of the GCS were selected based on guidelines (Chow, 1959; Froehlich, 2002) and engineering judgment because no similar features were in the model of existing conditions. Limited sensitivity analysis of the material and hydraulic properties of the GCS was performed.

The modifications of the vertical walls and other features in the GCS are potential sources of error in the model of proposed conditions. These modifications were necessary to be able to model the drop inlet, weir, side walls, and baffle blocks in FEWSMS. Vertical walls can act hydraulically different than sloped walls, particularly in the case of the drop inlet and weir; however, this source of error was minimized by making the walls as nearly vertical as possible without sacrificing model integrity and stability. The pier module was used to model the vertically faced baffle blocks in the concrete stilling basin. Whereas the width of the blocks was adjusted to maintain the correct cross-sectional area of blocked flow in the stilling basin, the extension of the blocks through the full depth of the water column is inconsistent with the physical structures.

\section{Analysis of Proposed Channel Modifications}

The overall Blue River Channel Modification project is designed to provide flood protection along the lower part of the Blue River. Cooper (1996) states:

"A major portion of the project is in a highly congested industrial area with numerous street, highway, and railroad bridges. The channel improvements were designed to contain a discharge of 991 $\mathrm{cu} \mathrm{m} / \mathrm{sec}(35,000 \mathrm{cfs})$ with a coincident 10 -yearfrequency flood on the Missouri River. This design discharge of $991 \mathrm{cu} \mathrm{m} / \mathrm{sec}(35,000 \mathrm{cfs})$ approximates a 30-year-frequency flood."

Channel modifications currently (2006) have been completed to a location immediately upstream from the mouth of Brush Creek (figs. 1 and 2). The two-dimensional model study area contains the proposed final stage of channel modifica- tions, with the GCS providing a transition of flow from the natural channel upstream to the modified channel downstream.

As discussed in the development of the model of proposed conditions, the proposed channel modificationsincluding the prototype weir, debris deflector, and concrete stilling basin-were hard-coded into the finite element mesh of the model of proposed conditions. In the following sections, the project design requirements and constraints of the proposed channel modifications and GCS are discussed, followed by a presentation of results from the two-dimensional models of existing and proposed conditions. Results from the WES physical model are presented as appropriate or available for comparison.

\section{Project Design Requirements and Constraints}

The design requirements of the overall project stated above also apply to the final stage of channel modifications; however, the transition from unmodified to modified channel creates unique issues that the GCS is designed to address. Concerning the GCS, Cooper (1996) states:

"A grade control structure near sta $99+60$ is the only major concrete structure planned as part of Stage III of the channel improvements. The structure will be located downstream from Byram's Ford (sta $113+50$ ) where it will not adversely impact the historic ford. The ford and associated Big Blue Battlefield, a Civil War historic area, was nominated to the National Register of Historic Places in October of 1989. The headwater elevations for the grade control structure were originally developed to allow a drawdown in the existing channel corresponding to a 5 percent differential in velocity upstream. A threestage weir design $* * *$ was necessary to provide acceptable velocities at all stages of flood flow. $* * *$ The lower stage of the weir was designed to prevent upstream ponding and sediment deposition at normal flows. $* * *$ The grade control structure was required to minimize the erosion that would result from the high velocities at the upstream end of the improved channel where the unmodified channel begins."

The channel modifications downstream from the GCS are designed to contain the 30-year flood, but the unmodified channel upstream from the GCS is not. Therefore, additional flood protection for the Byram's Ford Industrial Park was proposed in the form of a spoil berm along the left bank from 63d Street to the GCS. This spoil berm would be of sufficient height to contain the 30-year flood.

During the study on the GCS that was made using the WES physical model in 1996, "some emphasis was placed on finding a tradeoff point where the weir design did not adversely impact on the Byram's Ford Crossing but would provide additional flood protection of the Byram's Ford Industrial Park area" (Cooper, 1996). Furthermore, there was a desire to "ensure the integrity of the channel design while attempting 
to minimize the real estate requirements by the city of Kansas City" (Cooper, 1996). Finally, the WES physical model was to be used to verify the hydraulics of the proposed concrete and riprap stilling basin designs.

Although the WES physical model examined a considerable variety of weir, stilling basin, and spoil berm configurations for a range of discharges, results for the particular configuration used as the recommended prototype (type 25 weir, type 2 debris deflector, and type 1 concrete stilling basin) are limited (Cooper, 1996). Typically, location-specific data for the prototype are tabulated for the 30-year flood $\left(35,000 \mathrm{ft}^{3} / \mathrm{s}\right)$, but data for the 50-year flood $\left(44,500 \mathrm{ft}^{3} / \mathrm{s}\right)$ are not. Data for the 100 -year flood $\left(53,700 \mathrm{ft}^{3} / \mathrm{s}\right)$ are not specifically tabulated, but data for a discharge of $55,000 \mathrm{ft}^{3} / \mathrm{s}$ often are; therefore, the data tabulated for a discharge of $55,000 \mathrm{ft}^{3} / \mathrm{s}$ are used for comparison purposes to the 100-year flood. Occasionally, data for the 50-year flood are shown when they could be obtained from a curve or other graphical presentation.

The rating curve used to establish the downstream watersurface elevations for the Blue River channel without the GCS in the WES physical model assumed that no channel modifications had occurred and therefore reflects the pre-1983 conditions (Cooper, 1996; Helena Mosser, written commun., 2006). These downstream conditions are different from those used in the model of existing conditions. Therefore, direct comparison of the results of the pre-1983 conditions from the WES physical model and the model of existing conditions cannot be made.

\section{Overall Results}

In all of the simulations with the model of existing conditions, a rapid decrease in the water-surface elevations in the downstream part of the study area occurs in the vicinity of the transition from the unmodified channel to the modified channel (fig. 5). Substantial parts of both left and right flood plains are inundated in the 100-year flood (fig. 5C), and only slightly less inundation occurs in the 50-year flood (fig. 5B). Most of the residential area on the right flood plain and most of the Byram's Ford Industrial Park on the upstream left flood plain are not inundated in the 30-year flood (fig. 5A).

The modified channel in the model of proposed conditions contains the 30-year flood, and the Byram's Ford Industrial Park is protected by the spoil berm (fig. 11A), which fulfills the design requirements. The 50-year flood also is mostly contained by the modified channel, but the spoil berm is overtopped, resulting in inundation of the industrial park (fig. 11B). The 100-year flood (fig. 11C) has a similar inundation area to the 30-year flood in the model of existing conditions (fig. 5A), with little to no inundation for most of the right flood plain residential area along Hardesty Avenue and business district along Blue Parkway, but the Byram's Ford Industrial Park is inundated.

A comparison of results at several channel stations throughout the reach upstream from the GCS is shown in table
6. The simulated results from the model of proposed conditions appear closer to the results from the pre-1983 conditions from the WES physical model rather than to results from the proposed conditions from the WES physical model. This juxtaposition of results is readily apparent in a color-shaded relief map of the water-surface elevations for the 100-year flood (fig. 12), except for the area behind the spoil berm in the WES physical model. Nevertheless, the similarity of water-surface elevations in the model of proposed conditions and the WES physical model of pre-1983 conditions implies that the GCS creates conditions in the model of proposed conditions similar to those that existed in the channel before downstream channel modifications, as modeled in the WES physical model.

More water flows through Swope Park and over 63d Street on the right flood plain in the model of proposed conditions than in the WES physical model, whereas there is less flow through the GCS for the 100-year flood in the model of proposed conditions than in the WES physical model (table 7). These results imply that the GCS is holding back more water in the model of proposed conditions than was observed in the WES physical model, which also would explain the greater water-surface elevations upstream from the GCS (table 6). These results from the model of proposed conditions are similar to the results obtained from the WES physical model for the type 23 weir, which was similar to the type 25 weir except that it had an upper weir elevation of $774.28 \mathrm{ft}$ ( $4 \mathrm{ft}$ higher than the type 25 weir). Cooper (1996) states that the configuration of the type 23 weir resulted in 67 percent of the total flow $\left(36,800 \mathrm{ft}^{3} / \mathrm{s}\right.$ of $\left.55,000 \mathrm{ft}^{3} / \mathrm{s}\right)$ flowing over the weir and higher water-surface elevations upstream from the GCS.

The increased flow through Swope Park and over 63d Street in the model of proposed conditions might be presumed to be the result of more water being held back by the GCS, but the model of existing conditions shows similar results for flow over 63d Street without the GCS in place (table 7). Therefore, the lower rate of flow over $63 \mathrm{~d}$ Street in the WES physical model may be the result of differences in the application of the WES physical model and the other models. The lower rate of flow through the GCS may be the result of a similar difference.

Two possible, albeit unlikely, differences in application between the WES physical model and the two-dimensional models were examined to explain the differences in the rate of flow over 63d Street observed in the models: (1) a difference in the road embankment elevations for $63 \mathrm{~d}$ Street and (2) a difference in the distribution of flow along the upstream boundary. Specific road elevation and flow distributions were not available in Cooper's (1996) report; however, information in Cooper's report and inferred from video footage of the WES model runs (John Holm, written commun., 2004) imply these are not reasonable explanations. Elevations at several points in the flood plain upstream from 63d Street in Swope Park in the WES physical model are similar to those from the two-dimensional models. The elevation of $63 \mathrm{~d}$ Street is similar to the elevation of the flood plain in Swope Park in the twodimensional models, and the road and flood plain elevations 
Table 6. Simulated water-surface elevations along the channel centerline upstream from the proposed grade control structure for the 30-year and 100-year floods on the Blue River.

[ft, feet; $\mathrm{ft}^{3} / \mathrm{s}$, cubic feet per second; WES, Waterways Experiment Station; --, no data]

\begin{tabular}{|c|c|c|c|}
\hline \multirow[b]{3}{*}{ Station ${ }^{1}$} & \multicolumn{3}{|c|}{$\begin{array}{c}\text { Water-surface elevation } \\
\text { (ft) }\end{array}$} \\
\hline & \multicolumn{2}{|c|}{ WES physical model } & \multirow{2}{*}{$\begin{array}{c}\text { Two-dimensional } \\
\text { model of proposed } \\
\text { conditions }\end{array}$} \\
\hline & $\begin{array}{l}\text { Pre-1983 } \\
\text { conditions }\end{array}$ & $\begin{array}{l}\text { Proposed } \\
\text { conditions }\end{array}$ & \\
\hline \multicolumn{4}{|c|}{30 -year flood ${ }^{2}$} \\
\hline $102+00$ & 776.23 & -- & 776.28 \\
\hline $104+00$ & 776.56 & -- & 776.43 \\
\hline $106+00$ & 776.49 & -- & 776.53 \\
\hline $108+00$ & 776.59 & -- & 776.56 \\
\hline $110+00$ & 776.74 & -- & 776.55 \\
\hline $112+00$ & 776.67 & -- & 776.59 \\
\hline $113+50$ & 776.88 & -- & 776.78 \\
\hline $116+50$ & 776.88 & -- & 777.07 \\
\hline $120+15$ & 777.10 & -- & 777.14 \\
\hline $123+95$ & 777.35 & -- & 777.20 \\
\hline $128+60$ & 777.89 & -- & 777.32 \\
\hline $131+90$ & 777.53 & -- & 777.45 \\
\hline $135+50$ & 777.28 & -- & 777.59 \\
\hline \multicolumn{4}{|c|}{100 -year flood ${ }^{3}$} \\
\hline $102+00$ & 780.05 & 777.64 & 779.46 \\
\hline $104+00$ & 780.14 & 777.68 & 779.58 \\
\hline $106+00$ & 779.94 & 777.21 & 779.67 \\
\hline $108+00$ & 779.94 & 777.35 & 779.70 \\
\hline $110+00$ & 780.12 & 777.71 & 779.70 \\
\hline $112+00$ & 779.98 & 777.85 & 779.76 \\
\hline $113+50$ & 780.23 & 777.92 & 779.93 \\
\hline $116+50$ & 780.38 & 777.96 & 780.16 \\
\hline $120+15$ & 780.55 & 778.40 & 780.22 \\
\hline $123+95$ & 780.70 & 778.43 & 780.30 \\
\hline $128+60$ & 780.77 & 778.54 & 780.36 \\
\hline $131+90$ & 780.70 & 778.46 & 780.46 \\
\hline $135+50$ & 780.52 & 778.79 & 780.64 \\
\hline
\end{tabular}

${ }^{1}$ Stationing along unmodified Blue River channel centerline, from WES physical model, plate 2 (Cooper, 1996); shown in figure 12.

${ }^{2}$ Information for WES physical model is for $35,000 \mathrm{ft}^{3} / \mathrm{s}$ from table 16, water-surface elevations, with roughness (Cooper, 1996); no data are available for the proposed conditions from WES physical model. Information for model of proposed conditions is for $35,000 \mathrm{ft}^{3} / \mathrm{s}$.

${ }^{3}$ Infomation for WES physical model is for $55,000 \mathrm{ft}^{3} / \mathrm{s}$ from table 18 , water-surface elevations, with roughness, and Table 60 , watersurface elevations, unconfined flow, type 25 weir (Cooper, 1996). Information for model of proposed conditions is for $53,700 \mathrm{ft}^{3} / \mathrm{s}$. 


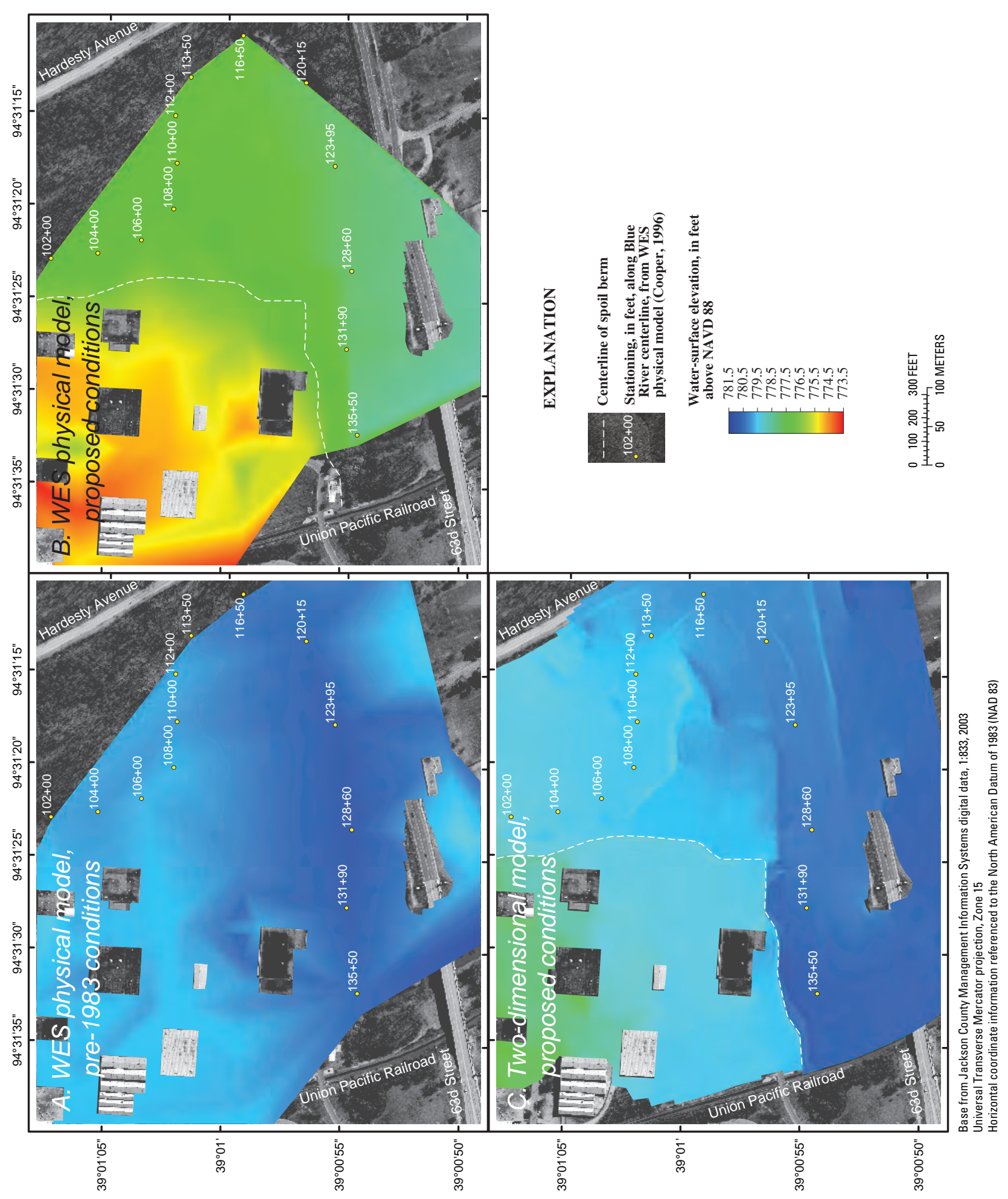

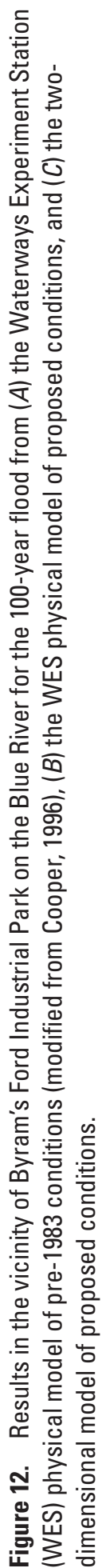


Table 7. Discharges for selected locations for the 30 -year and 100 -year floods on the Blue River.

[ft $\mathrm{ft}^{3} / \mathrm{s}$, cubic feet per second; WES, Waterways Experiment Station; --, not applicable]

\begin{tabular}{|c|c|c|c|c|c|c|c|c|c|}
\hline \multirow[b]{2}{*}{ Model } & \multirow[b]{2}{*}{$\begin{array}{l}\text { Total } \\
\text { flow } \\
\left(\mathrm{ft}^{3} / \mathrm{s}\right)\end{array}$} & \multicolumn{2}{|c|}{$\begin{array}{c}\text { Under 63d Street } \\
\text { Bridge }\end{array}$} & \multicolumn{2}{|c|}{$\begin{array}{c}\text { Through Swope Park } \\
\text { and over 63d Street }\end{array}$} & \multicolumn{2}{|c|}{$\begin{array}{l}\text { Through grade } \\
\text { control structure }\end{array}$} & \multicolumn{2}{|c|}{$\begin{array}{c}\text { Over spoil berm and } \\
\text { through industrial } \\
\text { park }\end{array}$} \\
\hline & & $\begin{array}{l}\text { Flow } \\
\left(\mathrm{ft}^{3} / \mathrm{s}\right)\end{array}$ & $\begin{array}{l}\text { Percent- } \\
\text { age of } \\
\text { total }\end{array}$ & $\begin{array}{l}\text { Flow } \\
\left(\mathrm{ft}^{3} / \mathrm{s}\right)\end{array}$ & $\begin{array}{l}\text { Percent- } \\
\text { age of } \\
\text { total }\end{array}$ & $\begin{array}{l}\text { Flow } \\
\left(\mathrm{ft}^{3} / \mathrm{s}\right)\end{array}$ & $\begin{array}{l}\text { Percent- } \\
\text { age of } \\
\text { total }\end{array}$ & $\begin{array}{l}\text { Flow } \\
\left(\mathrm{ft}^{3} / \mathrm{s}\right)\end{array}$ & $\begin{array}{c}\text { Percent- } \\
\text { age of } \\
\text { total }\end{array}$ \\
\hline \multicolumn{10}{|c|}{ 30-year flood } \\
\hline $\begin{array}{l}\text { Proposed } \\
\text { conditions }\end{array}$ & 35,000 & 21,300 & 60.9 & 13,700 & 39.1 & 35,000 & 100.0 & 0 & 0 \\
\hline $\begin{array}{l}\text { Existing } \\
\text { conditions }\end{array}$ & 35,000 & 23,400 & 66.9 & 11,600 & 33.1 & -- & -- & -- & -- \\
\hline \multicolumn{10}{|c|}{ 100-year flood } \\
\hline $\begin{array}{l}\text { Existing } \\
\text { conditions }\end{array}$ & 53,700 & 32,200 & 60.0 & 21,500 & 40.0 & -- & -- & -- & -- \\
\hline
\end{tabular}

${ }^{1}$ From Cooper (1996).

are presumed to be similar in the WES physical model. In the two-dimensional models, the flow was distributed across the entire upstream boundary of the model as the inflow flux line; in the video footage of the WES physical model runs, flow appears to be distributed over the entire upstream boundary.

A third-and more likely-explanation for the lower rate of flow over 63d Street in the WES physical model is the flow behavior of the material used to model roughness on the overbanks. The WES physical model primarily was constructed of wood and concrete, with structures and other particular features being formed from wood, plastic, sand, and gravel (Cooper, 1996). Initial runs with the physical model indicated that "significant roughness" had to be added to the model to match computed water-surface elevations in the reach. Cooper (1996) states:

"A screen wire material was placed on the channel bottom to produce the appropriate roughness for flows contained in the channel $* * *$. A porous rubberized material (commonly referred to as horsehair) was used to produce the desired roughness on the overbanks. Masonry bricks were used to hold this material in place. An aerial photograph furnished by the Kansas City District showed locations of heavy tree growth. The roughness material was placed in the model in the locations to match the heavy tree growth $* * * . "$

These rubberized horsehair mats were distributed approximately as shown in figure 13 . Water flowed over the mats at locations where the mats were in the channel or on the banks, and water generally flowed along the mats at locations along the edges of the flood plains. In the area where the Blue River parallels $63 \mathrm{~d}$ Street, water in the main channel flowed along the mats; however, water crossing 63d Street had to flow transversely across the mats. Furthermore, depths of flow across $63 \mathrm{~d}$ Street may have been such that the water did not flow over the mats but had to flow through them. Although there is heavy tree growth in the reach between the 63d Street Bridge and Byram's Ford where the river parallels 63d Street, the rubberized horsehair mats were placed in a single, relatively narrow strip along the downstream edge of the road. Although Cooper (1996) describes this material as "porous," the material itself and the placement of masonry bricks may have limited the flow of water transversely through the mats, which would have caused flow to be deflected back to the main channel rather than over the road embankment.

This third explanation also may explain the difference in volume of flow through the GCS. Initially, this difference was thought to be the result of the roughness and turbulence parameters assigned to the baffle block area, but a simulation of the 100-year flood with different roughness coefficients for the baffle block area $(0.10$ for the lower value and 0.05 for the upper value) resulted in essentially no change (about $0.02 \mathrm{ft}$ ) in the water-surface elevations upstream from the GCS and only $300 \mathrm{ft}^{3} / \mathrm{s}$ ( 0.6 percent) of additional flow through the GCS (a total of $38,800 \mathrm{ft}^{3} / \mathrm{s}$, or 72.3 percent). The lack of substantial change was expected because the drop inlet and upper weir of the GCS generally cause the flow to approach critical depth (the flow-regime transition point between subcritical, downstream-controlled flow and supercritical, upstream-controlled flow), which makes the GCS a point of local flow control and, 

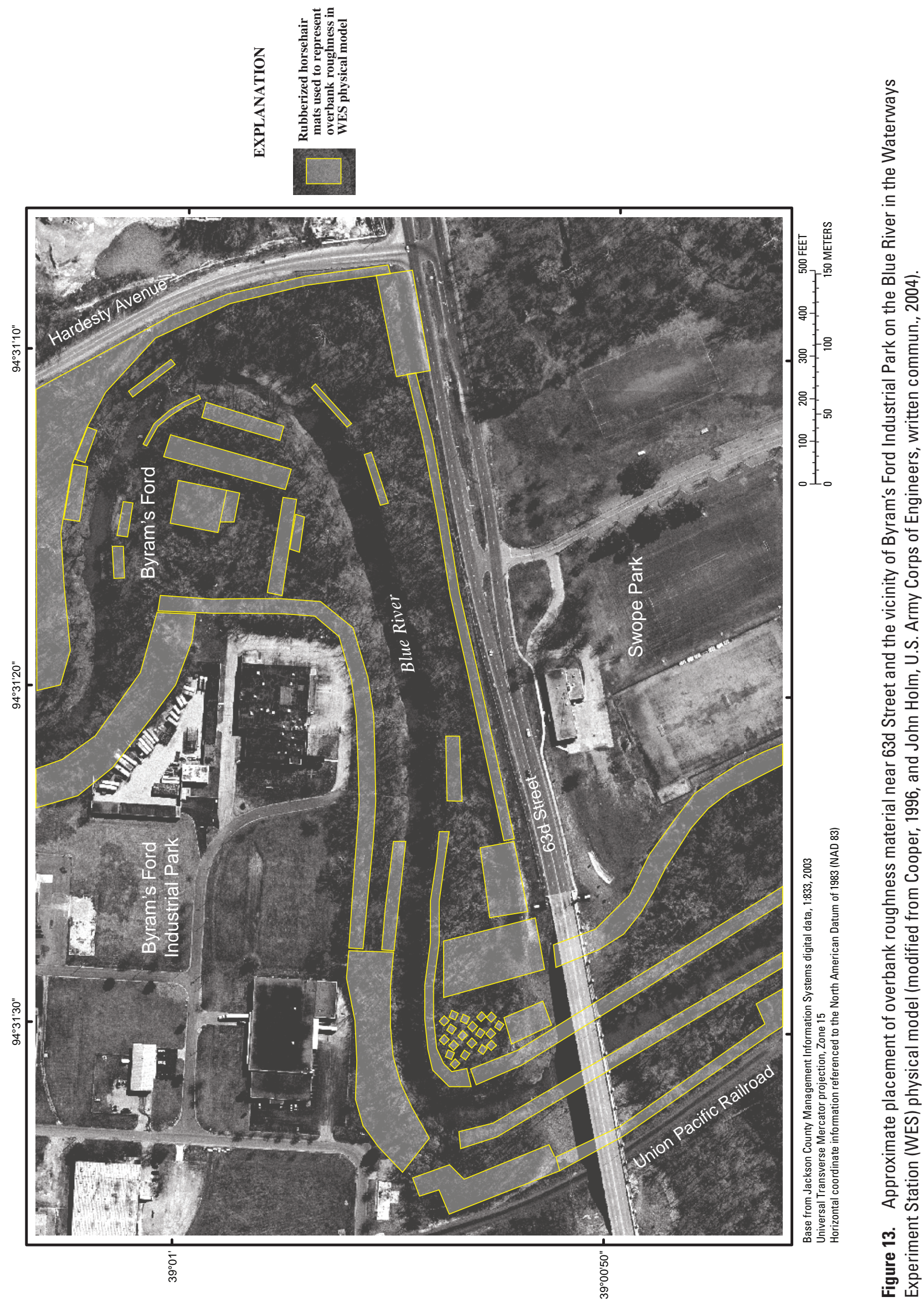
therefore, changes made downstream from the drop inlet and upper weir will have a limited effect on flow upstream.

For discharges that caused overtopping of the spoil berm in the WES physical model, the discharge on the left floodplain through Byram's Ford Industrial Park would have had to flow transversely through the mats along the left bank. As stated previously, however, the rubberized horsehair mats and masonry bricks may have limited the flow of water transversely through the mats, which would have caused flow to be contained to the main channel rather than allowed to overtop the spoil berm. This would result in more water flowing through the GCS and less on the left floodplain.

In the riprap stilling basin downstream from the GCS, water-surface elevations from the model of proposed conditions are about the same (only $0.1 \mathrm{ft}$ higher) as they are in the WES physical model for the 50- and 100-year floods (table 8); however, the water-surface elevation for the 30-year flood is substantially lower $(1.5 \mathrm{ft})$ in the model of proposed conditions than in the WES physical model. The discrepancies in the water-surface elevations for the 30-year flood are main- tained throughout most of the riprap stilling basin downstream from the GCS as shown in table 9, and likely are the result of higher velocities in the riprap stilling basin in the model of proposed conditions as compared to the velocities from the WES physical model. At the transition from the riprap stilling basin into the modified downstream channel, however, the differences in water-surface elevation begin to diminish.

A similar trend of water-surface elevation changes was seen in the riprap stilling basin for $55,000 \mathrm{ft}^{3} / \mathrm{s}$ in the WES physical model (plate 60 in Cooper, 1996), except that the water-surface elevation at the transition into the modified channel did not drop as far below the water-surface elevation at the upstream end of the riprap stilling basin as was seen in the 30-year flood (from $771.1 \mathrm{ft}$ at the upstream end to 770.7 $\mathrm{ft}$ at the downstream). The similarity in water-surface elevation at the upstream and downstream ends of the riprap stilling basin likely is the result of increased flow in the flood plain adjacent to the modified channel and the additional flow over the spoil berm and around the GCS. Flow in these areas of increased roughness had an effect on depths of flow in the

Table 8. Water-surface elevations in the modified channel downstream from the proposed grade control structure on the Blue River.

$\left[\mathrm{ft}^{3} / \mathrm{s}\right.$, cubic feet per second; WES, Waterways Experiment Station; ft, feet]

\begin{tabular}{lccc}
\hline Modeled flood & $\begin{array}{c}\text { Discharge } \\
\left(\mathbf{f t}^{3} / \mathbf{s}\right)\end{array}$ & $\begin{array}{c}\text { Water-surface elevation in WES physical } \\
\text { model of proposed condtions } \mathbf{1}^{\mathbf{2}} \\
\text { (ft) }\end{array}$ & $\begin{array}{c}\text { Water-surface elevation in model } \\
\text { of proposed conditions } \\
\text { (ft) }\end{array}$ \\
\hline 30-year & 35,000 & 759.3 & 757.8 \\
50-year & 44,500 & 762.9 & 763.0 \\
100-year & 53,700 & 766.3 & 766.4 \\
\hline
\end{tabular}

${ }^{1}$ From plate 4, tailwater rating curve, sta 97+02.5 (Cooper, 1996).

Table 9. Water-surface elevations along the left trail levee downstream from the proposed grade control structure for the 30-year flood (35,000 cubic feet per second) on the Blue River.

[ft, feet; WES, Waterways Experiment Station; $\mathrm{ft}^{3} / \mathrm{s}$, cubic feet per second]

\begin{tabular}{ccc}
\hline $\begin{array}{c}\text { Distance downstream } \\
\text { from the end sill } \\
\text { (ft) }\end{array}$ & $\begin{array}{c}\text { Water-surface elevation in WES } \\
\text { physical model of proposed conditions' } \\
\text { (ft) }\end{array}$ & $\begin{array}{c}\text { Water-surface elevation in model of } \\
\text { proposed conditions } \\
\text { (ft) }\end{array}$ \\
\hline 0 & 759.3 & 757.9 \\
50 & 760.3 & 757.9 \\
100 & 761.0 & 757.9 \\
150 & 761.6 & 757.9 \\
200 & 761.8 & 758.0 \\
250 & 761.2 & 758.1 \\
300 & 759.5 & 758.1 \\
350 & 758.6 & 758.0 \\
400 & 757.3 & 757.7 \\
\hline
\end{tabular}

${ }^{1}$ From plate 59, trail levee water-surface profile, discharge 35,000 ft³/s, tailwater elevation 759.71 (Cooper, 1996). 
Table 10. Change in water-surface elevation from the downstream boundary to the upstream end of the modified channel from the model of proposed conditions on the Blue River.

$\left[\mathrm{ft}^{3} / \mathrm{s}\right.$, cubic feet per second; $\mathrm{ft}$, feet $]$

\begin{tabular}{lcccc}
\hline Modeled flood & $\begin{array}{c}\text { Wischarge } \\
\left(\mathbf{f t}^{3} / \mathbf{s}\right)\end{array}$ & $\begin{array}{c}\text { Water-surface } \\
\text { elevation at down- } \\
\text { stream boundary } \\
(\mathbf{f t})\end{array}$ & $\begin{array}{c}\text { Water-surface elevation } \\
\text { at upstream end of } \\
\text { modified channel } \\
(\mathbf{f t})\end{array}$ & $\begin{array}{c}\text { Difference } \\
(\mathbf{f t})\end{array}$ \\
\hline 30-year & 35,000 & 756.19 & 757.94 & 1.75 \\
50 -year & 44,500 & 761.17 & 763.23 & 2.06 \\
100 -year & 53,700 & 764.07 & 766.62 & 2.55 \\
\hline
\end{tabular}

downstream channel, as can be seen in the downstream watersurface elevations from the model of proposed conditions in figure 11 and table 10; water-surface elevations increase more substantially from the downstream boundary to the upstream end of the modified channel in the 50-year flood (fig. 11B; table 10) and even more in the 100-year flood (fig. $11 C$; table 10) as compared to the 30-year flood (fig. 11A; table 10). Therefore, although specific water-surface data in the modified channel are not tabulated in the Cooper (1996) report for the 50- and 100-year floods in the WES physical model, the results from the model of proposed conditions are thought to be similar to those observed in the WES physical model in the modified channel based on the similarity of the water-surface elevations in the riprap stilling basin and at the transition into the modified channel.

\section{Results at Byram's Ford Historic Crossing}

The effect of the proposed channel changes on the historic crossing of Byram's Ford was of critical interest in the WES physical model and the current study. An increase in velocity in the ford could result in damaging erosion, whereas decreased velocity could result in sedimentation. Secondarily, an increase in depth of flow would result in more inundated area in the Byram's Ford Industrial Park. A decrease in depth likely would result in increased velocity in the ford.

\section{Comparison of Results to Existing Conditions (2006)}

Simulated results from the two-dimensional models in the vicinity of Byram's Ford are shown in figures 14 through 17 and are shown with comparable results from the WES physical model in table 11. For the 30-year flood (fig. 14; table 11), the maximum depth in the model of proposed conditions is $43.5 \mathrm{ft}$, as compared to $39.7 \mathrm{ft}$ in the model of existing conditions - an increase of $3.8 \mathrm{ft}$. The maximum velocity magnitude in the model of proposed conditions is $4.55 \mathrm{ft} / \mathrm{s}$, as compared to $6.61 \mathrm{ft} / \mathrm{s}$ in the model of existing conditions-a decrease of about $2.1 \mathrm{ft} / \mathrm{s}$. As noted in the overall results and in table 6 for the 30 -year flood, the maximum velocity in the model of pro- posed conditions seems to compare well with the maximum velocity of $4.5 \mathrm{ft} / \mathrm{s}$ from the WES physical model of pre-1983 conditions. This similarity of results in the model of proposed conditions and the WES physical model of pre-1983 conditions implies that the GCS creates conditions in the model of proposed conditions similar to those that existed in the channel before downstream channel modifications, as modeled in the WES physical model.

For the 50-year flood (fig. 15; table 11), the maximum depth in the model of proposed conditions is $45.8 \mathrm{ft}$ compared to $42.3 \mathrm{ft}$ in the model of existing conditions, which is an increase of $3.5 \mathrm{ft}$. The maximum velocity magnitude in the model of proposed conditions is $4.16 \mathrm{ft} / \mathrm{s}$ compared to 6.12 $\mathrm{ft} / \mathrm{s}$ in the model of existing conditions, which is a decrease of about $2.0 \mathrm{ft} / \mathrm{s}$.

For the 100-year flood (fig. 16; table 11), the maximum depth in the model of proposed conditions is $46.6 \mathrm{ft}$ compared to $44.0 \mathrm{ft}$ in the model of existing conditions - an increase of $2.6 \mathrm{ft}$. The maximum velocity magnitude in the model of proposed conditions is $4.12 \mathrm{ft} / \mathrm{s}$ compared to $5.64 \mathrm{ft} / \mathrm{s}$ in the model of existing conditions - a decrease of approximately 1.5 $\mathrm{ft} / \mathrm{s}$. Again, the maximum velocity in the model of proposed conditions is similar to the velocity of $4.7 \mathrm{ft} / \mathrm{s}$ from the WES physical model of pre-1983 conditions.

For the discharge data from the flood of May 15, 1990, as simulated in the model of existing conditions (1990 flood) (fig. 17; table 11), the maximum depth in the model of proposed conditions is $42.0 \mathrm{ft}$ compared to $38.4 \mathrm{ft}$ in the model of existing conditions (1990 flood) - an increase of $3.6 \mathrm{ft}$. The maximum velocity magnitude in the model of proposed conditions is $4.84 \mathrm{ft} / \mathrm{s}$ compared to $6.54 \mathrm{ft} / \mathrm{s}$ in the model of existing conditions (1990 flood) — a decrease of $1.7 \mathrm{ft} / \mathrm{s}$.

\section{Comparison of Results to Historical Conditions (1990)}

The consistent increase in the depth of flow from existing conditions to proposed conditions would result in increased inundation of the area upstream from the GCS, and the consistent decrease in maximum velocity from existing conditions to proposed conditions could result in potential sedimentation in 

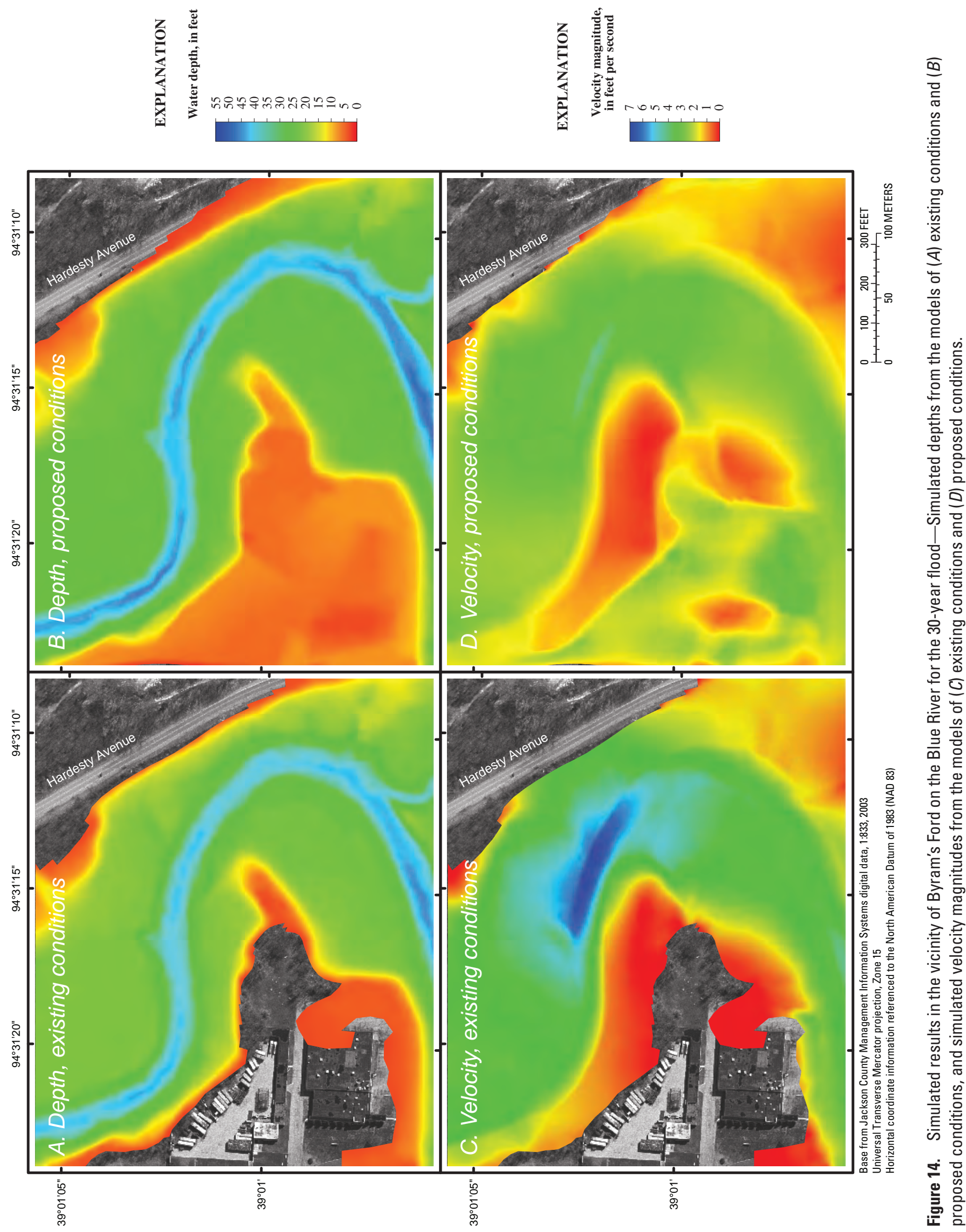


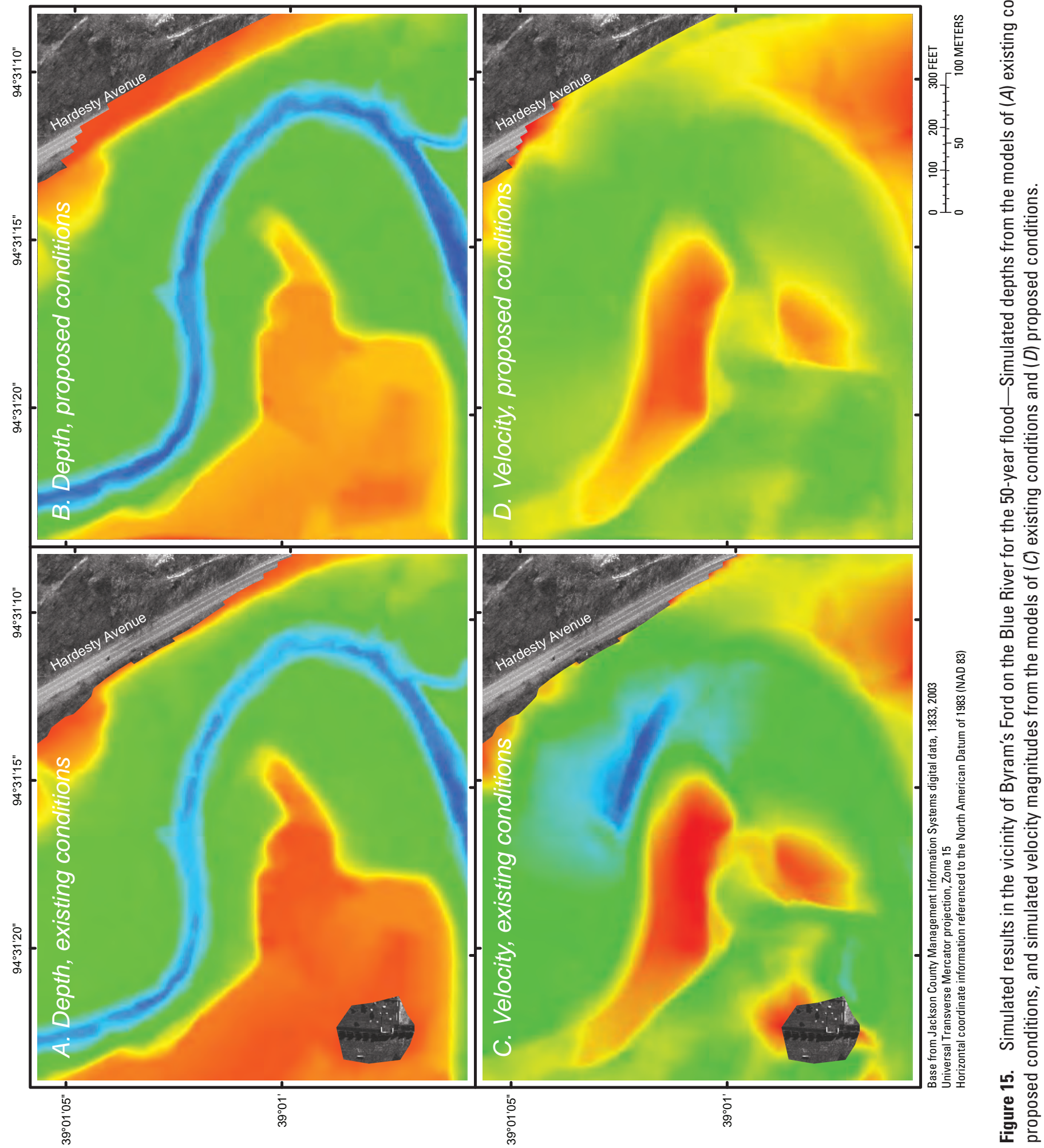



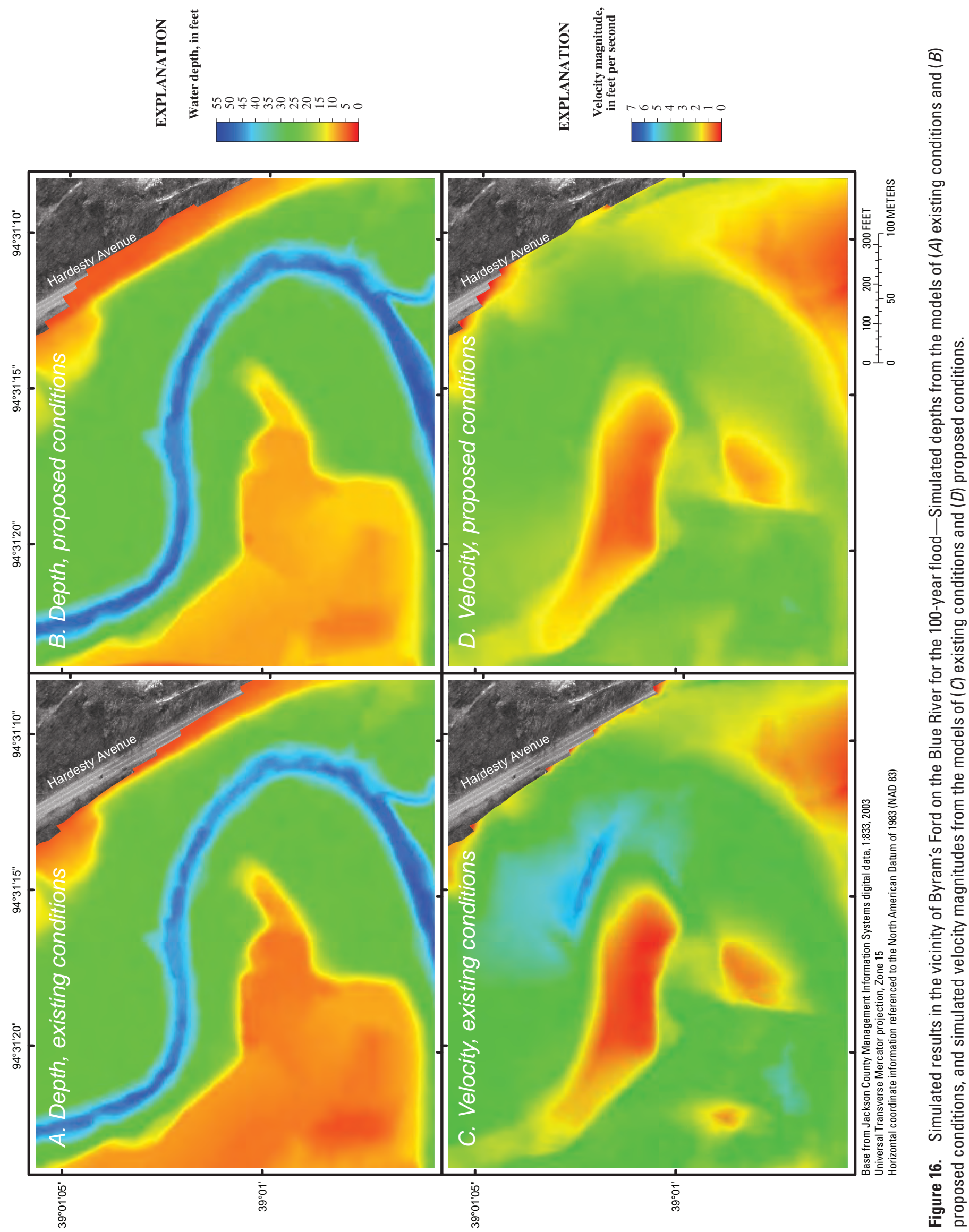

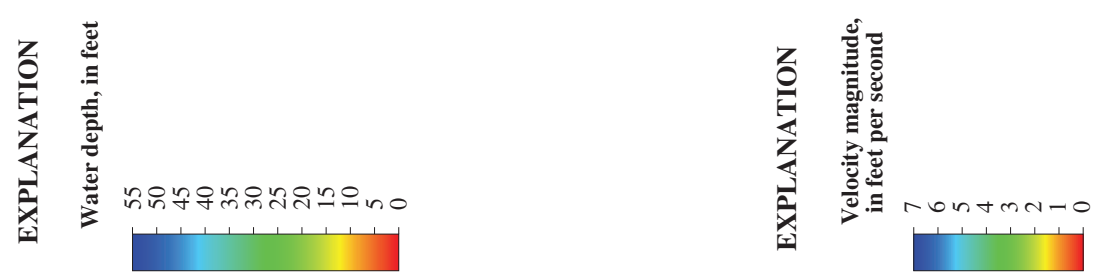

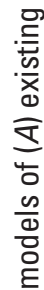

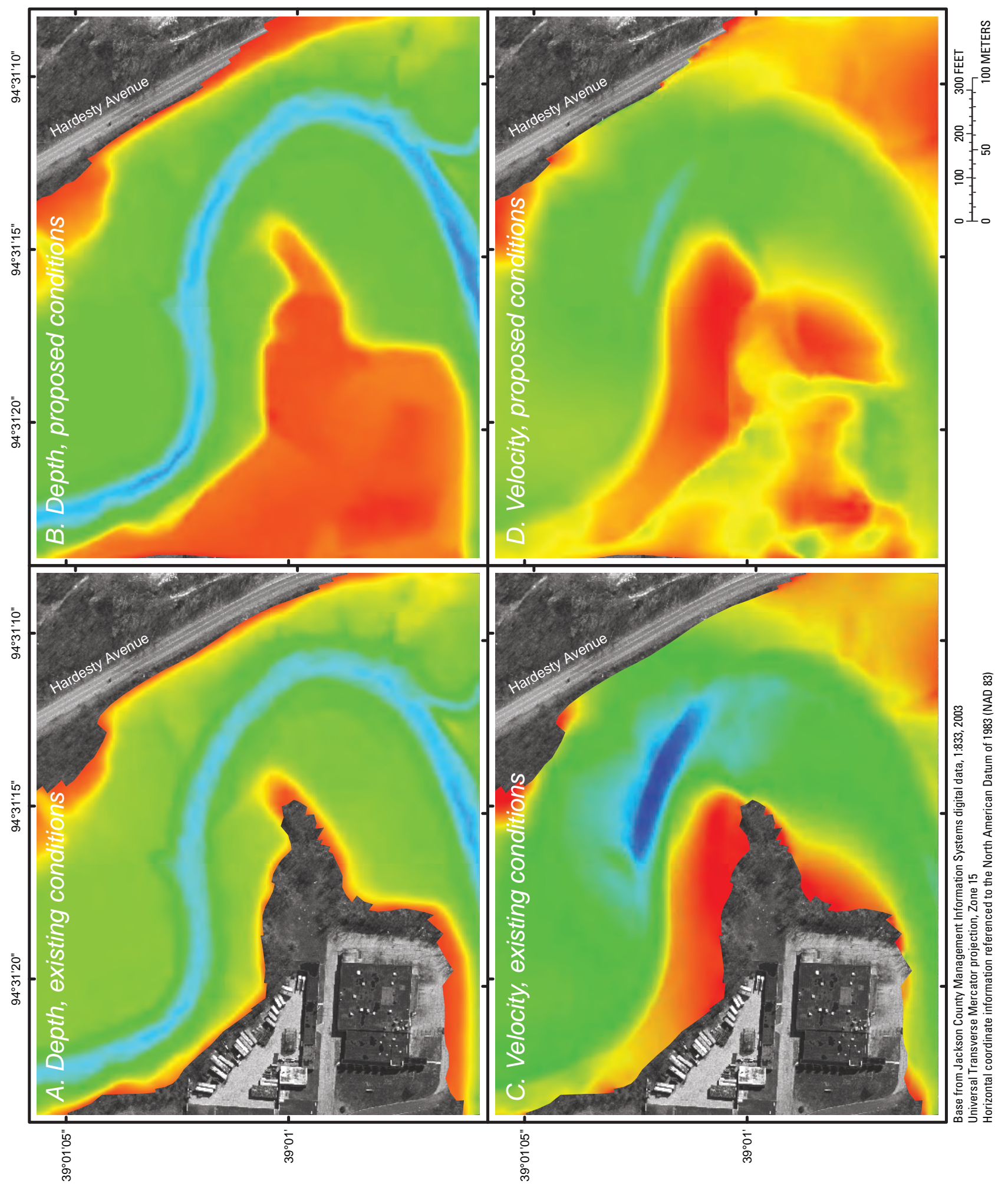

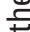

는

동 응

음 등

동 잉

흠 잉

क 은

옹

드 들

ते

$\sum_{4}^{0}$

홍 웅

은 묻

兵敂

ㄷํㅇ

$=$

它

는 $\frac{\infty}{0}$

응 을

$\stackrel{\oplus}{\subseteq}$

흔 흔

क

동

$\stackrel{0}{\underline{D}}$

$\overline{\boldsymbol{D}}$

$\stackrel{\widetilde{\pi}}{E}$

든

혼 음

인

$\because 8$

歾

के ह.

눙

츰

. ํㅡㄴ

읗

. 엉

폭 잉

ఏ응

인 을

元

ज 등

도

흔 
Table 11. Maximum simulated results in the vicinity of Byram's Ford on the Blue River

$\left[\mathrm{ft}^{3} / \mathrm{s}\right.$, cubic feet per second; ft, feet; ft/s, feet per second; WES, Waterways Experiment Station; --, no data]

\begin{tabular}{|c|c|c|c|c|c|c|c|}
\hline \multirow[b]{3}{*}{ Modeled flood } & \multirow[b]{3}{*}{$\begin{array}{c}\text { Discharge } \\
\left(\mathrm{ft}^{3} / \mathbf{s}\right)\end{array}$} & \multicolumn{4}{|c|}{ Two-dimensional models } & \multicolumn{2}{|c|}{ WES physical model } \\
\hline & & \multicolumn{2}{|c|}{ Existing conditions } & \multicolumn{2}{|c|}{ Proposed conditions } & \multirow{2}{*}{$\begin{array}{c}\text { Pre-1983 } \\
\text { conditions } \\
\text { velocity } \\
\text { (ft/s) }\end{array}$} & \multirow{2}{*}{$\begin{array}{c}\text { Proposed } \\
\text { conditions } \\
\text { velocity }{ }^{2} \\
\text { (ft/s) }\end{array}$} \\
\hline & & $\begin{array}{c}\text { Depth } \\
\text { (ft) }\end{array}$ & $\begin{array}{c}\text { Velocity } \\
(\mathrm{ft} / \mathrm{s})\end{array}$ & $\begin{array}{c}\text { Depth } \\
\text { (ft) }\end{array}$ & $\begin{array}{c}\text { Velocity } \\
(\mathrm{ft} / \mathrm{s})\end{array}$ & & \\
\hline 30-year & 35,000 & 39.7 & 6.61 & 43.5 & 4.55 & 4.5 & 6.1 \\
\hline 50-year & 44,500 & 42.3 & 6.12 & 45.8 & 4.16 & -- & -- \\
\hline 100-year & 53,700 & 44.0 & 5.64 & 46.6 & 4.12 & ${ }^{3} 4.7$ & ${ }^{3} 5.6$ \\
\hline $\begin{array}{l}1990 \text { flood } \\
\quad\left(\text { existing conditions) }{ }^{4}\right.\end{array}$ & 31,800 & 38.4 & 6.54 & 42.0 & 4.84 & -- & -- \\
\hline $\begin{array}{l}1990 \text { flood } \\
\text { (historic conditions) }\end{array}$ & 31,800 & 41.5 & 5.09 & 42.0 & 4.84 & -- & -- \\
\hline
\end{tabular}

${ }^{1}$ From tables 72-73, velocities at Byram's Ford, existing conditions (Cooper, 1996).

${ }^{2}$ From tables 83-84, velocities at Byram's Ford, unconfined flow, type 25 weir (Cooper, 1996).

${ }^{3}$ Results are for a discharge of $55,000 \mathrm{ft}^{3} / \mathrm{s}$.

${ }^{4}$ Results for existing conditions are from model of existing conditions (1990 flood).

${ }^{5}$ Results for existing conditions are from model of historic conditions.

the Byram's Ford area. It should be noted that these results are based on the proposed conditions and the existing conditions (as of 2006), whereas the GCS is designed to create conditions in the upstream channel that are similar to those that existed before channel modification began in 1983.

The simulated water-surface elevations for the discharge from the 1990 flood in the vicinity of Byram's Ford Industrial Park as computed in the model of historic conditions, in the model of existing conditions (1990 flood), and in the model of proposed conditions are shown in figure 18. The watersurface elevations from the model of proposed conditions are extremely similar to the results from the model of historic conditions, whereas the water-surface elevations from the model of existing conditions (1990 flood) are substantially lower than the results from the other simulations. Furthermore, the simulated depths and velocities for the 1990 flood discharge from the model of proposed conditions in the vicinity of Byram's Ford are extremely similar to the results from the model of historic conditions (fig. 19; table 11). In table 11, the maximum depth in the model of proposed conditions is $42.0 \mathrm{ft}$ as compared to $41.5 \mathrm{ft}$ in the model of historic conditions, which is an increase of only $0.5 \mathrm{ft}$. Also, the maximum velocity in the model of proposed conditions is $4.84 \mathrm{ft} / \mathrm{s}$ as compared to $5.09 \mathrm{ft} / \mathrm{s}$ in the model of historic conditions, a decrease of only $0.25 \mathrm{ft} / \mathrm{s}$. For the May 15, 1990, flood, the GCS appears to create backwater conditions in the upstream channel that are similar to those that existed in 1990, except that the spoil berm provides flood protection for the Byram's Ford Industrial Park (fig. 18).

\section{Implications of Change in Historical Conditions (1990) to Existing Conditions (2006)}

The channel modifications that have already been completed on the Blue River up to the mouth of Brush Creek appear to have an effect on flows in the unmodified channel upstream from Brush Creek. Visual observations during the May 19, 2004, flood indicate that flow through the unmodified section of the reach downstream from the lower Blue Parkway Bridge was "very rapid and turbulent" (Paul Rydlund, Jr., U.S. Geological Survey, oral commun., 2006), and the simulated velocities are higher in the reach downstream from the lower Blue Parkway Bridge than elsewhere in the study area for that flood (fig. 20). The increased velocity in the downstream part of the study area may result in increased velocities throughout the study area; the velocities simulated for the May 15, 1990, flood as it occurred in 1990 (model of historic conditions) and velocities simulated for that flood if it occurred with the current downstream modifications (model of existing conditions (1990 flood)) show increases throughout the study area from 1990 to 2006 (fig. 21).

Increased velocities throughout the study area will result in a decrease in water-surface elevations for a given discharge. This decrease can be seen in the simulated water-surface elevations for the May 15, 1990, flood (fig. 18B) and the decrease in inundation area (figs. 18 and 21). The modified channel is designed to contain the 30-year flood, and the Byram's Ford Industrial Park will have supplemental protection in the form of the spoil berm; however, the simulated water-surface eleva- 


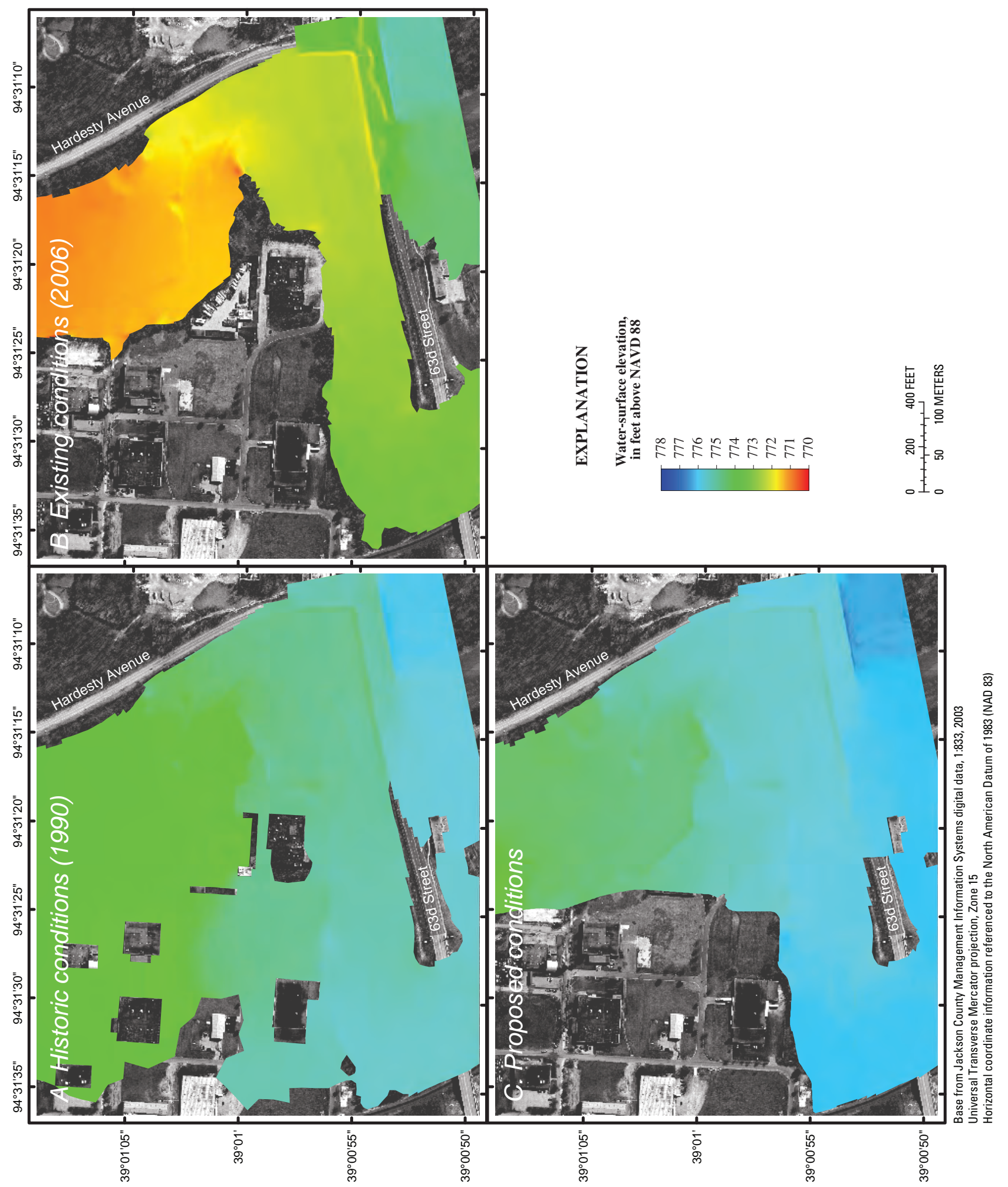

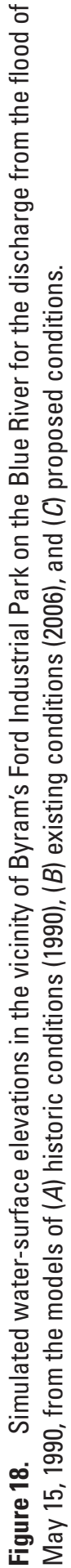



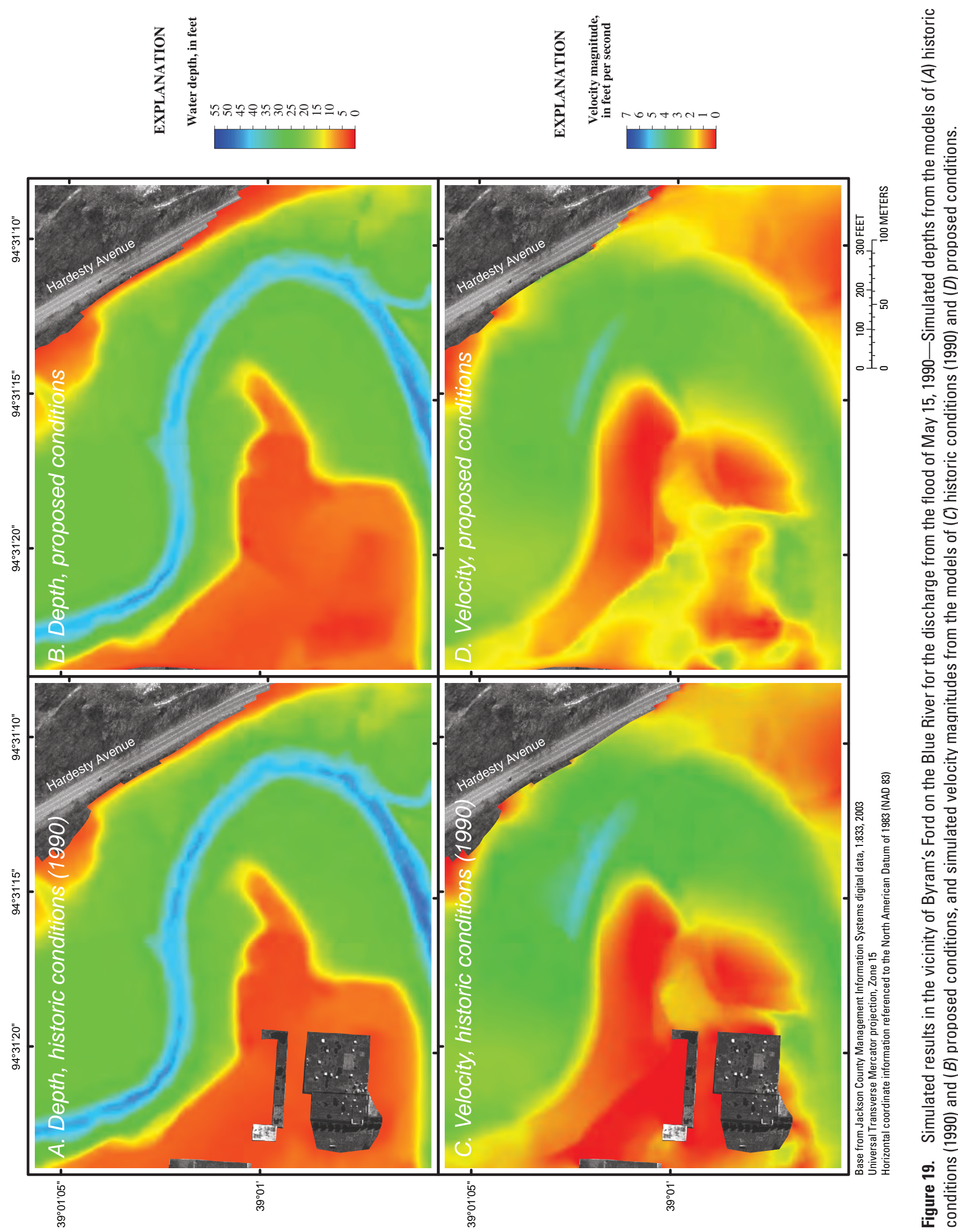


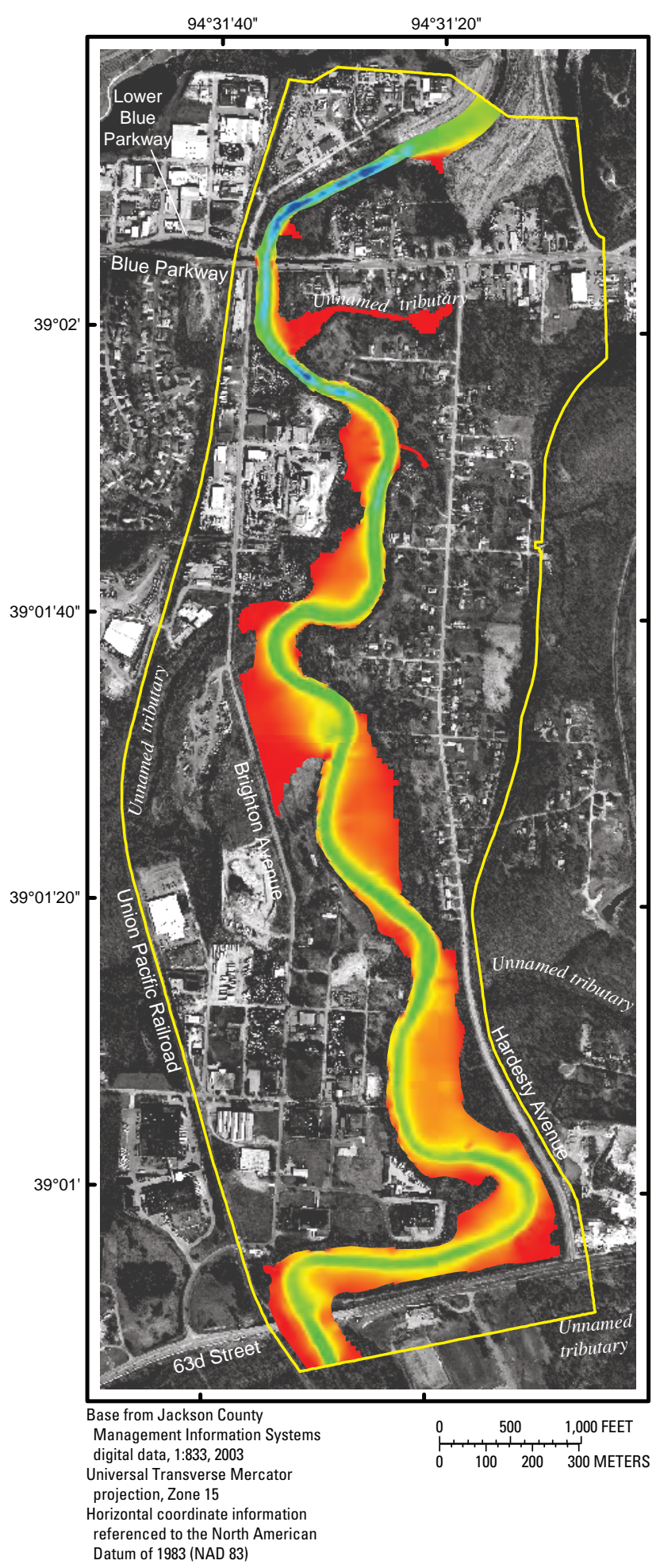

EXPLANATION

Velocity magnitude, in feet per second

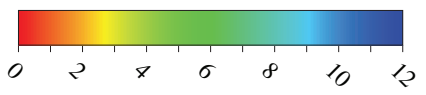

Figure 20. Simulated velocity magnitudes on the Blue River from the calibration to the flood of May 19, 2004. tions from the model of existing conditions for the 30-year flood (fig. $5 \mathrm{~A}$ ) show that the downstream channel modifications have already resulted in a measure of flood protection for the Byram's Ford Industrial Park for the 30-year flood.

The increased velocities throughout the study area, however, also may result in degradation in the unmodified channel. Areas of bank instability and sloughing in Swope Park in the reach upstream from 63d Street have occurred (John Holm, oral commun., 2006), which could be the result of increased velocities in the numerous meander bends in the park. Similar bank instability or other degradation of the channel would be harmful to the historic crossing at Byram's Ford.

Although the downstream channel modifications are having an effect on the unmodified upstream channel, the simulations with the model of proposed conditions show that the GCS would reduce flow velocities and increase flow depths upstream from the structure. The similarity of results for the May 15, 1990, flood data in the model of historic conditions and the model of proposed conditions implies that the GCS likely would create conditions similar to those that existed before downstream channel modifications began. Furthermore, the consistent similarity of the model of proposed conditions and the WES physical model of pre-1983 conditions also implies that the GCS would create conditions in the twodimensional model similar to those that existed in the channel before downstream channel modifications, as modeled in the WES physical model.

\section{Results in Riprap Stilling Basin}

The concrete stilling basin provides substantial energy dissipation for the flow transition from the unmodified to the modified channel, but the riprap stilling basin downstream from the GCS may experience substantial velocities during extreme floods. Therefore, velocities in the riprap stilling basin downstream from the GCS were necessary to appropriately design the riprap in the basin.

Cooper (1996) provides velocity magnitudes that were measured $2 \mathrm{ft}$ above the channel bed at locations throughout the riprap stilling basin for the 30-year flood. These channel-bottom velocity magnitudes are compared to the depthaveraged velocity magnitudes from the model of proposed conditions in figure 22. Whereas a direct comparison of the results cannot be made because a point velocity cannot be obtained from FESWMS Flo2DH, two key similarities are observed: (1) there is an area of high velocity in the center of the channel immediately downstream from the end sill of the concrete stilling basin, and (2) velocities increase as flow transitions from the basin into the downstream channel. The velocity magnitudes simulated in the model of proposed conditions are greater than those measured in the WES physical model, principally because they represent a full-depth average of the entire velocity profile in the water column, whereas the WES physical model values are point velocities measured near the channel bed. The channel-bottom velocity magnitudes 


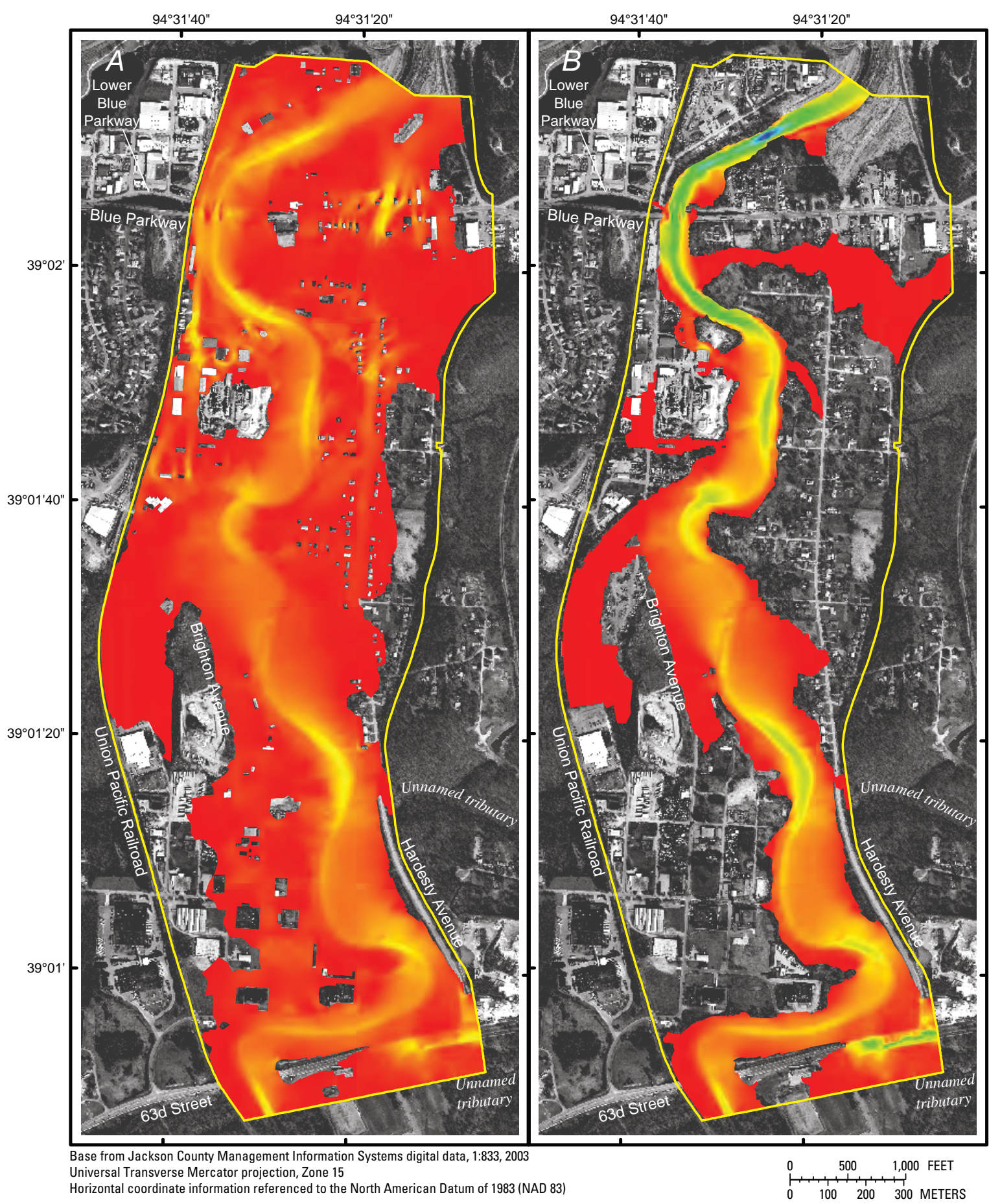

EXPLANATION

Velocity magnitude, in feet per second

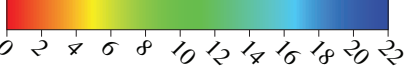

Figure 21. Simulated velocity magnitudes on the Blue River for the discharge from the flood of May 15, 1990, from the models of $(A)$ historic conditions (1990) and $(B)$ existing conditions. 


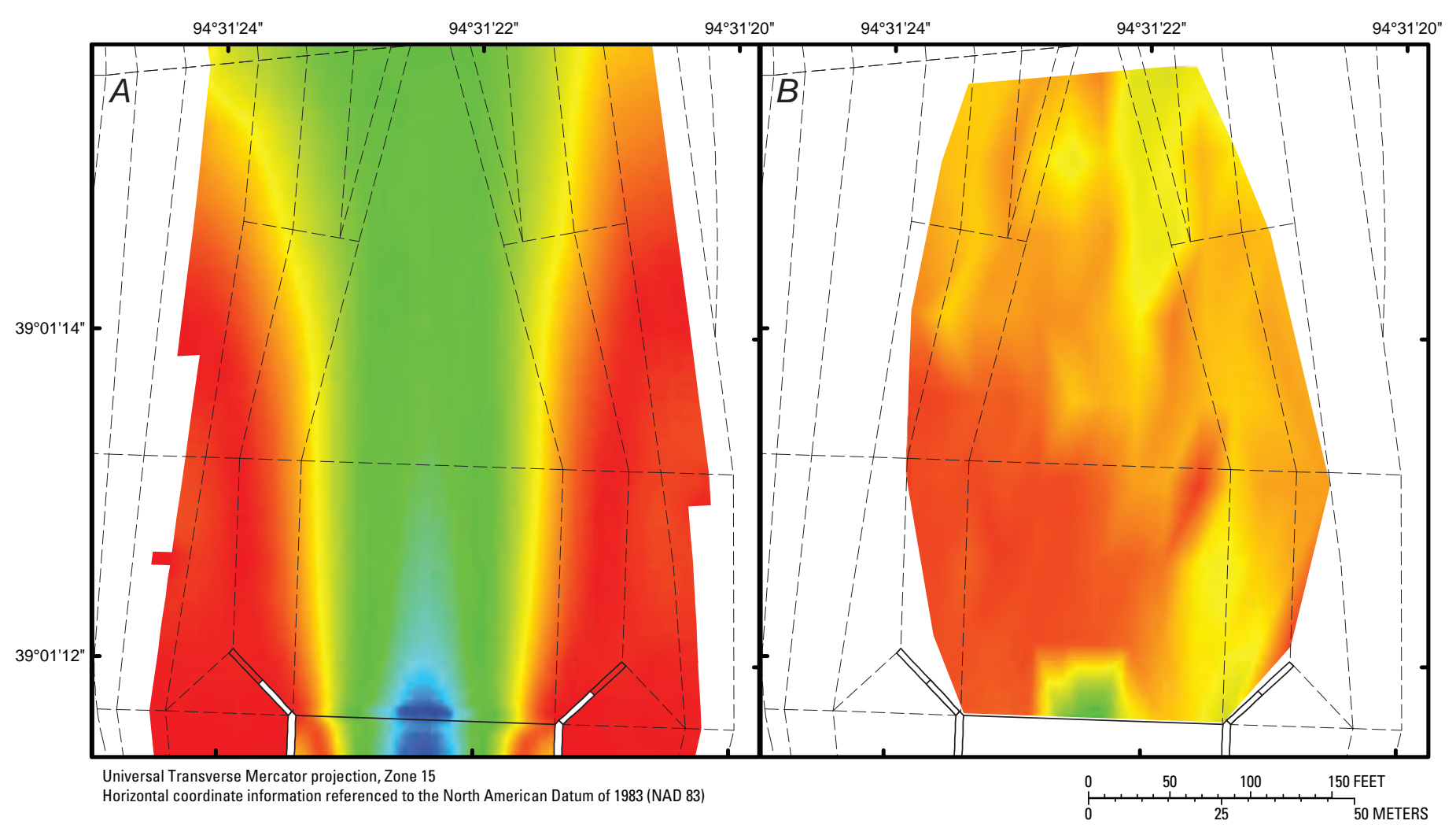

EXPLANATION

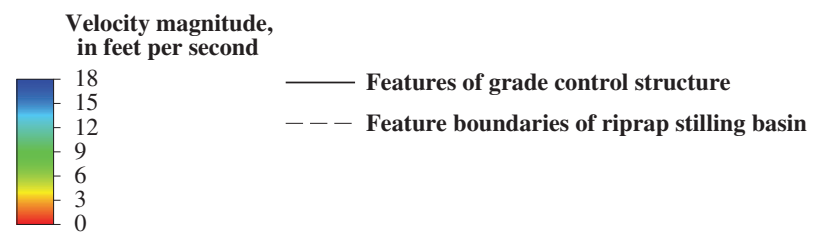

Figure 22. (A) Depth-averaged velocity magnitudes simulated in the model of proposed conditions and $(B)$ channel-bottom velocity magnitudes as measured 2 feet above the channel bed in the Waterways Experiment Station (WES) physical model (modified from Cooper, 1996) in the riprap stilling basin for the 30 -year flood on the Blue River.

from the WES physical model imply a concentration of higher velocity along the right side of the basin, but this trend is not seen in the model of proposed conditions.

Depth-averaged velocity magnitudes for flow through the GCS and into the modified downstream channel for the 30-, 50 -, and 100-year floods are shown in figure 23. As discharge increases, more flow goes over the upper weir stage, which decreases the velocity in the GCS throat. Furthermore, as discharge increases above the 30-year discharge, more flow goes over the upstream spoil berm, which further reduces velocities in the GCS and the downstream channel. For the 30-year flood, velocity reaches a maximum of about $34.3 \mathrm{ft} / \mathrm{s}$ in the throat of the drop inlet/weir and decreases to about $9.5 \mathrm{ft} / \mathrm{s}$ at the transition from the riprap stilling basin to the downstream channel. For the 50-year flood, the maximum velocity in the throat of the GCS is about $31.2 \mathrm{ft} / \mathrm{s}$ and decreases to about $8.6 \mathrm{ft} / \mathrm{s}$ at the transition. For the 100-year flood, the maximum velocity in the throat of the GCS is about $28.7 \mathrm{ft} / \mathrm{s}$ and decreases to about $7.6 \mathrm{ft} / \mathrm{s}$ at the transition. Velocity magni- tudes upstream from the GCS are remarkably similar for all simulated floods, with a velocity magnitude of approximately $4.5 \mathrm{ft} / \mathrm{s}$ at the upstream edge of the riprap apron upstream from the GCS debris deflectors, and with maximum velocity magnitudes ranging from $4.0 \mathrm{ft} / \mathrm{s}$ to $4.5 \mathrm{ft} / \mathrm{s}$ in the vicinity of Byram's Ford (figs. 14 through 17).

\section{Results in Modified Channel Bends and Locations of Riprap Placement}

The WES physical model extended $800 \mathrm{ft}$ downstream from the weir, about $400 \mathrm{ft}$ downstream from the transition from the riprap stilling basin to the modified channel. Therefore, no flow information is available from the physical model for the modified channel downstream from the GCS. The model of proposed conditions incorporated all of the proposed channel modifications, including channel bends and locations of riprap placement; water-surface elevations and velocity 


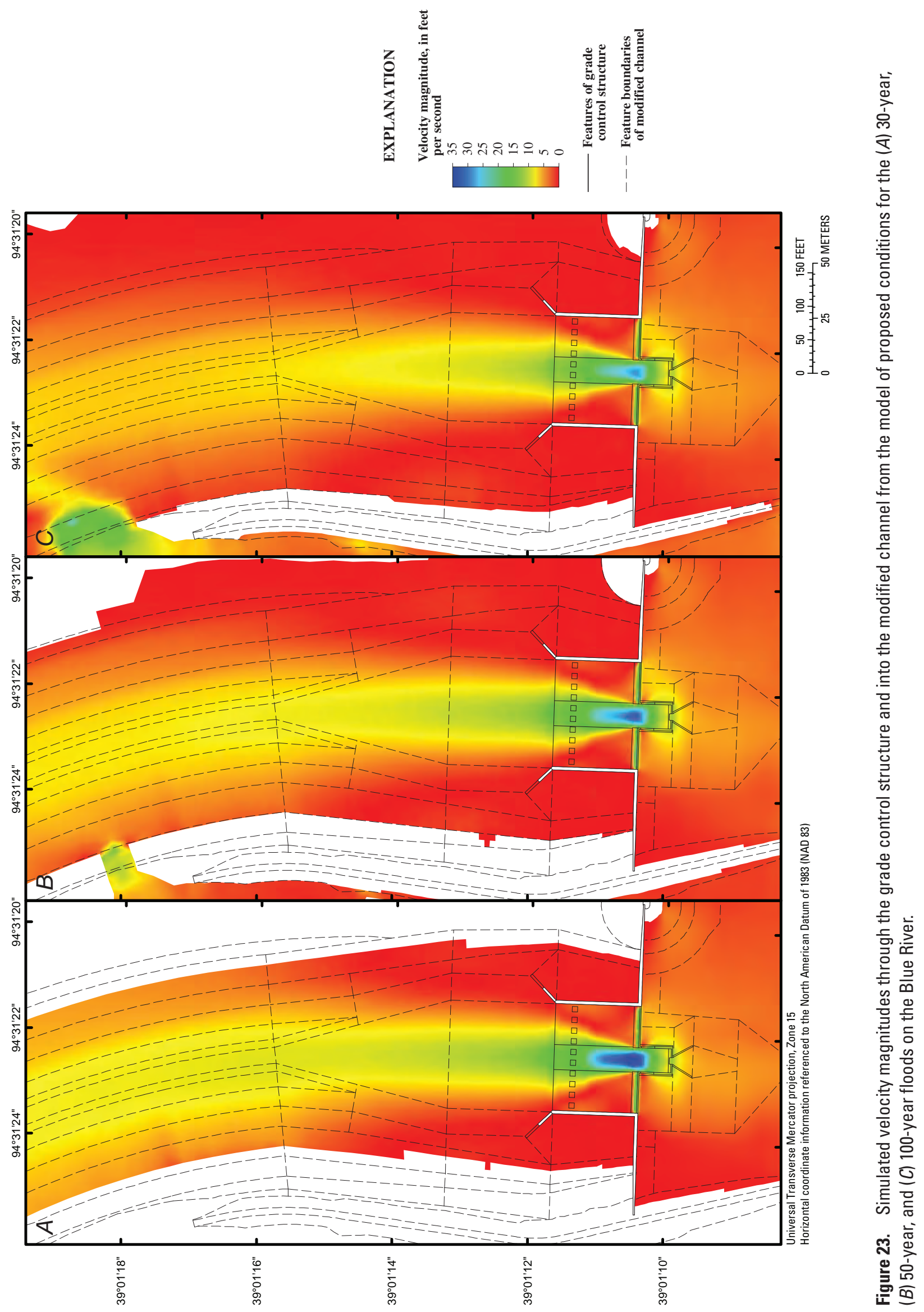


Table 12. Simulated water-surface elevations along the modified channel centerline downstream from the proposed grade control structure for the 30-year, 50-year, and 100-year floods on the Blue River.

[ft, feet; $\mathrm{ft}^{3} / \mathrm{s}$, cubic feet per second; --, no data]

\begin{tabular}{|c|c|c|c|}
\hline \multirow[b]{2}{*}{ Station ${ }^{1}$} & \multicolumn{3}{|c|}{$\begin{array}{l}\text { Water-surface elevation } \\
\text { (ft) }\end{array}$} \\
\hline & $\begin{array}{c}30 \text {-year flood } \\
\left(35,000 \mathrm{ft}^{3} / \mathrm{s}\right)\end{array}$ & $\begin{array}{l}50 \text {-year flood } \\
\left(44,500 \mathrm{ft}^{3} / \mathrm{s}\right)\end{array}$ & $\begin{array}{c}100 \text {-year flood } \\
\left(53,700 \mathrm{ft}^{3} / \mathrm{s}\right)\end{array}$ \\
\hline $49+00$ & 757.47 & 762.70 & 766.15 \\
\hline $50+00$ & 757.95 & 763.10 & 766.48 \\
\hline $51+00$ & 758.07 & 763.22 & 766.57 \\
\hline $52+00$ & 758.06 & 763.28 & 766.63 \\
\hline $53+00$ & 757.95 & 763.25 & 766.63 \\
\hline $54+00$ & 757.94 & 763.26 & 766.65 \\
\hline $55+00$ & 757.95 & 763.26 & 766.65 \\
\hline $56+00$ & 757.94 & 763.22 & 766.59 \\
\hline $57+00$ & 757.93 & 763.19 & 766.39 \\
\hline $58+00$ & 757.91 & 763.18 & 766.22 \\
\hline $59+00$ & 757.90 & 763.16 & 766.21 \\
\hline $60+00$ & 757.88 & 763.15 & 766.23 \\
\hline $61+00$ & 757.87 & 763.13 & 766.24 \\
\hline $62+00$ & 757.85 & 763.12 & 766.24 \\
\hline $63+00$ & 757.83 & 763.10 & 766.22 \\
\hline $64+00$ & 757.82 & 763.09 & 766.18 \\
\hline $65+00$ & 757.81 & 763.06 & 766.15 \\
\hline $66+00$ & 757.80 & 763.01 & 766.13 \\
\hline $67+00$ & 757.77 & 762.93 & 766.07 \\
\hline $68+00$ & 757.75 & 762.88 & 766.02 \\
\hline $69+00$ & 757.73 & 762.85 & 765.98 \\
\hline $70+00$ & 757.71 & 762.82 & 765.94 \\
\hline $71+00$ & 757.69 & 762.80 & 765.91 \\
\hline $72+00$ & 757.67 & 762.78 & 765.89 \\
\hline $73+00$ & 757.65 & 762.76 & 765.86 \\
\hline $74+00$ & 757.64 & 762.73 & 765.83 \\
\hline $75+00$ & 757.62 & 762.71 & 765.81 \\
\hline $76+00$ & 757.61 & 762.69 & 765.78 \\
\hline $77+00$ & 757.59 & 762.67 & 765.75 \\
\hline $78+00$ & 757.58 & 762.65 & 765.72 \\
\hline $79+00$ & 757.67 & 762.72 & 765.77 \\
\hline
\end{tabular}


Table 12. Simulated water-surface elevations along the modified channel centerline downstream from the proposed grade control structure for the 30-year, 50-year, and 100-year floods on the Blue River.-Continued [ft, feet; $\mathrm{ft}^{3} / \mathrm{s}$, cubic feet per second; --, no data]

\begin{tabular}{|c|c|c|c|}
\hline \multirow[b]{2}{*}{ Station ${ }^{1}$} & \multicolumn{3}{|c|}{$\begin{array}{l}\text { Water-surface elevation } \\
\text { (ft) }\end{array}$} \\
\hline & $\begin{array}{c}30 \text {-year flood } \\
\left(35,000 \mathrm{ft}^{3} / \mathrm{s}\right)\end{array}$ & $\begin{array}{c}50 \text {-year flood } \\
\left(44,500 \mathrm{ft}^{3} / \mathrm{s}\right)\end{array}$ & $\begin{array}{c}\text { 100-year flood } \\
\left(53,700 \mathrm{ft}^{3} / \mathrm{s}\right)\end{array}$ \\
\hline $80+00$ & 757.52 & 762.61 & 765.64 \\
\hline $81+00$ & 757.46 & 762.56 & 765.58 \\
\hline $82+00$ & 757.45 & 762.53 & 765.54 \\
\hline $83+00$ & 757.44 & 762.51 & 765.51 \\
\hline $84+00$ & 757.42 & 762.49 & 765.48 \\
\hline $85+00$ & 757.41 & 762.47 & 765.45 \\
\hline $86+00$ & 757.39 & 762.46 & 765.44 \\
\hline $87+00$ & 757.39 & 762.45 & 765.44 \\
\hline $88+00$ & 757.37 & 762.43 & 765.43 \\
\hline $89+00$ & 757.35 & 762.41 & 765.41 \\
\hline $90+00$ & 757.34 & 762.39 & 765.39 \\
\hline $91+00$ & 757.31 & 762.37 & 765.37 \\
\hline $92+00$ & 757.28 & 762.33 & 765.33 \\
\hline $93+00$ & 757.27 & 762.32 & 765.30 \\
\hline $94+00$ & 757.25 & 762.29 & 765.26 \\
\hline $95+00$ & 757.23 & 762.26 & 765.22 \\
\hline $96+00$ & 757.20 & 762.23 & 765.19 \\
\hline $97+00$ & 757.18 & 762.19 & 765.16 \\
\hline $98+00$ & 757.16 & 762.18 & 765.15 \\
\hline $99+00$ & 757.16 & 762.18 & 765.17 \\
\hline $100+00$ & 757.17 & 762.18 & 765.19 \\
\hline $101+00$ & 757.19 & 762.20 & 765.21 \\
\hline $102+00$ & 757.11 & 762.12 & 765.11 \\
\hline $103+00$ & 757.01 & 762.03 & 765.00 \\
\hline $104+00$ & 756.96 & 761.98 & 764.93 \\
\hline $105+00$ & 756.96 & 761.97 & 764.94 \\
\hline $106+00$ & 756.96 & 761.96 & 764.94 \\
\hline $107+00$ & 756.50 & 761.52 & 764.48 \\
\hline $108+00$ & 756.49 & 761.50 & 764.44 \\
\hline $109+00$ & 756.46 & 761.47 & 764.39 \\
\hline $110+00$ & 756.44 & 761.44 & 764.36 \\
\hline
\end{tabular}


Table 12. Simulated water-surface elevations along the modified channel centerline downstream from the proposed grade control structure for the 30-year, 50-year, and 100-year floods on the Blue River.-Continued

[ft, feet; $\mathrm{ft}^{3} / \mathrm{s}$, cubic feet per second; --, no data]

\begin{tabular}{|c|c|c|c|}
\hline \multirow[b]{2}{*}{ Station ${ }^{1}$} & \multicolumn{3}{|c|}{$\begin{array}{l}\text { Water-surface elevation } \\
\text { (ft) }\end{array}$} \\
\hline & $\begin{array}{l}30 \text {-year flood } \\
\left(35,000 \mathrm{ft}^{3} / \mathrm{s}\right)\end{array}$ & $\begin{array}{l}50 \text {-year flood } \\
\left(44,500 \mathrm{ft}^{3} / \mathrm{s}\right)\end{array}$ & $\begin{array}{c}\text { 100-year flood } \\
\left(53,700 \mathrm{ft}^{3} / \mathrm{s}\right)\end{array}$ \\
\hline $111+00$ & 756.42 & 761.41 & 764.33 \\
\hline $112+00$ & 756.39 & 761.38 & 764.29 \\
\hline $113+00$ & 756.37 & 761.36 & 764.26 \\
\hline $114+00$ & 756.35 & 761.34 & 764.24 \\
\hline $115+00$ & 756.34 & 761.32 & 764.23 \\
\hline $116+00$ & 756.33 & 761.31 & 764.22 \\
\hline $117+00$ & 756.32 & 761.29 & 764.20 \\
\hline $118+00$ & 756.31 & 761.28 & 764.20 \\
\hline $119+00$ & 756.29 & 761.26 & 764.19 \\
\hline $120+00$ & 756.28 & 761.25 & 764.17 \\
\hline $121+00$ & 756.27 & 761.23 & 764.16 \\
\hline $122+00$ & 756.28 & 761.23 & 764.15 \\
\hline $123+00$ & 756.29 & 761.24 & 764.15 \\
\hline $124+00$ & 756.27 & 761.22 & 764.13 \\
\hline $125+00$ & 756.23 & 761.20 & 764.10 \\
\hline $125+66^{2}$ & 756.19 & 761.17 & 764.07 \\
\hline
\end{tabular}

${ }^{1}$ Stationing along modified Blue River channel centerline (John Holm, written commun., 2006); shown in figure 24B.

${ }^{2}$ Approximate station of downstream boundary of model of proposed conditions.

magnitudes in these areas provide information about the adequacy of the riprap design.

Simulated water-surface elevations at stations along the modified channel centerline downstream from the GCS are shown in table 12 . This stationing is consistent with stationing in the currently (2006) modified channel downstream from the study area; however, it is inconsistent with the unmodified channel centerline stationing upstream from the GCS (table 6; fig. 12). Lines of equal water-surface elevation for the 100year flood from the models of existing and proposed conditions are shown in figure 24.

Riprap will be placed in various locations throughout the study area (fig. 10). It is to be placed on both sides of the modified channel along the entire study area, covering the 1 on 3 slope above the 1 on 70 slope shown in figure 9 , to limit wave-induced erosion at the water-to-air interface in typical low-flow conditions. Riprap also will be placed on the channel bed and sides of two primary tributaries where they join the main channel, and it will line the numerous drains into the channel from fill areas along the study area. The entire stilling basin downstream from the concrete stilling basin will be covered with riprap, as will the bed and sides of the approach channel upstream from the GCS.

Velocity magnitudes for flow throughout the reach downstream from the GCS for the 30-, 50-, and 100-year floods are shown in figure 25 . The velocity magnitudes are extremely similar for the three floods. For the 30-year flood, velocities along the channel centerline generally ranged from 7.0 to 8.5 $\mathrm{ft} / \mathrm{s}$, with an average of $7.7 \mathrm{ft} / \mathrm{s}$ and a local maximum of $8.7 \mathrm{ft} / \mathrm{s}$ between the piers of the Blue Parkway Bridge. For the 50-year flood, velocities along the centerline generally ranged from 7.1 to $7.8 \mathrm{ft} / \mathrm{s}$, with an average of $7.4 \mathrm{ft} / \mathrm{s}$ and a local maximum of $8.8 \mathrm{ft} / \mathrm{s}$ between the piers of the Blue Parkway Bridge. For the 100-year flood, velocities generally ranged from $7.4 \mathrm{ft} / \mathrm{s}$ to $8.0 \mathrm{ft} / \mathrm{s}$, with an average of $7.7 \mathrm{ft} / \mathrm{s}$ and a local maximum of $9.1 \mathrm{ft} / \mathrm{s}$ between the piers of the Blue Parkway Bridge. Inflow from the tributaries was not considered when analyzing the mainstem peak flood wave in the simulated floods because the 


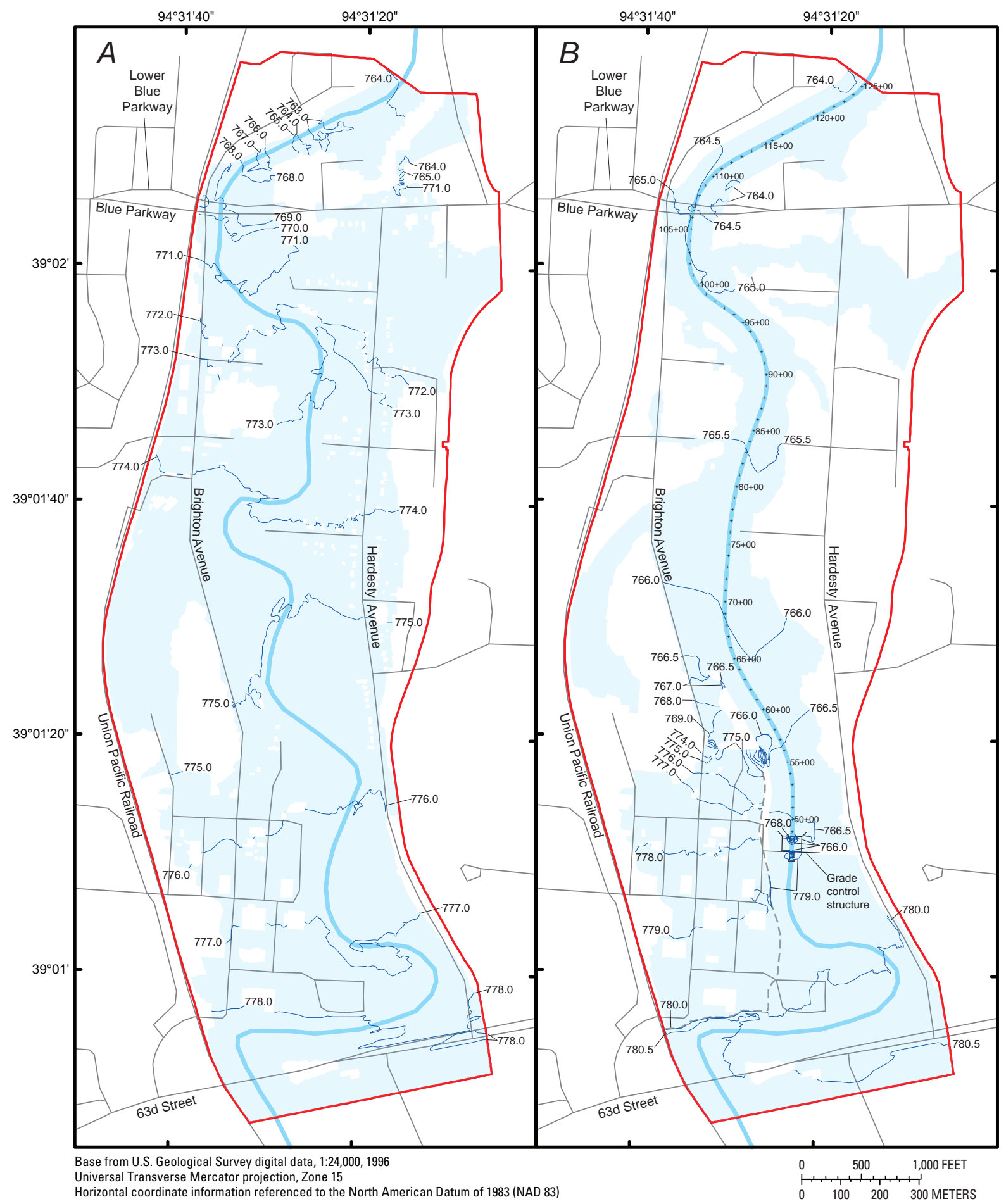

EXPLANATION

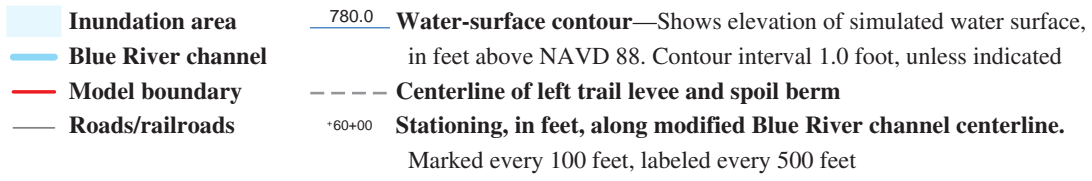

Figure 24. Simulated water-surface elevations with contours from the models of $(A)$ existing conditions and $(B)$ proposed conditions for the 100-year flood on the Blue River. 


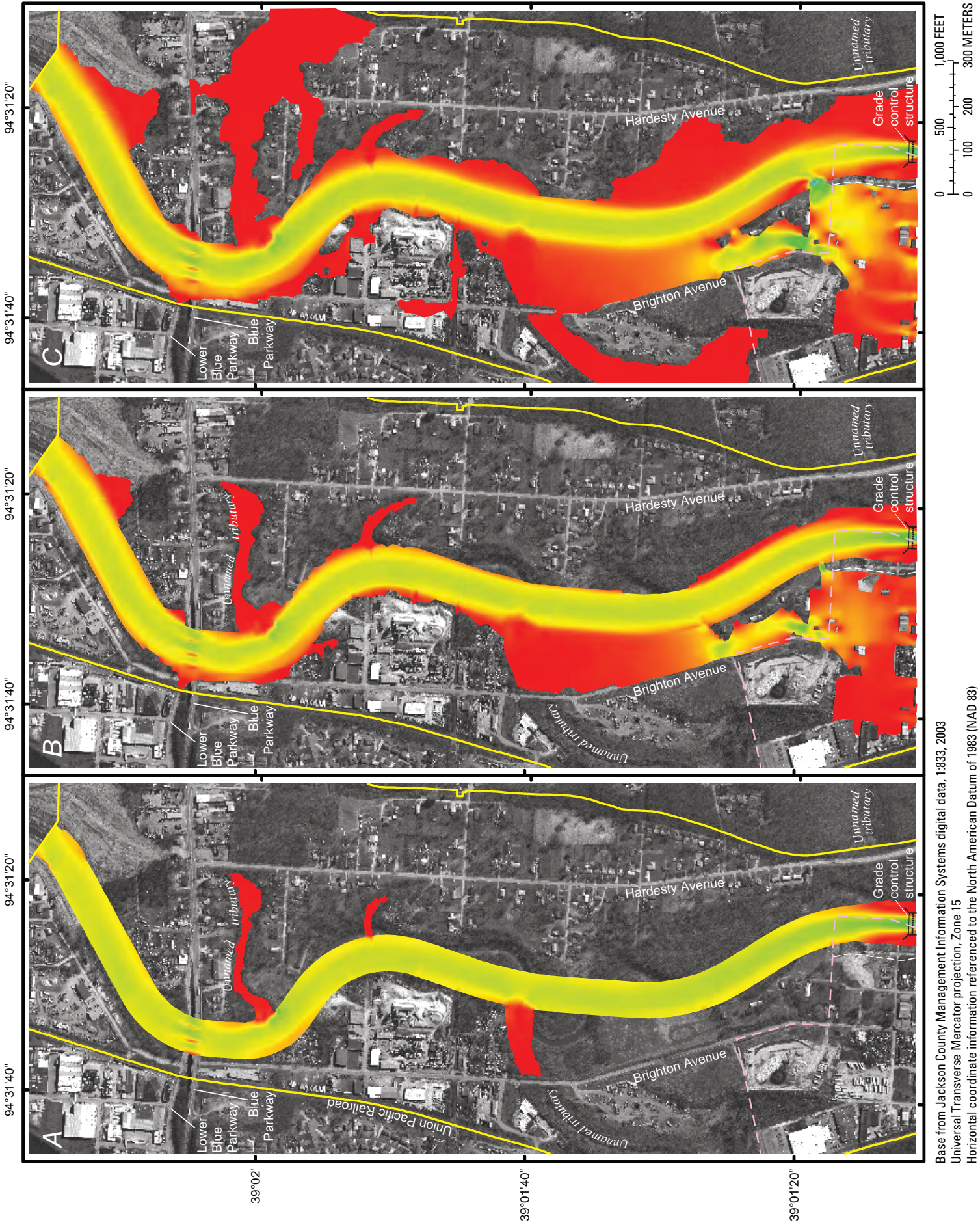

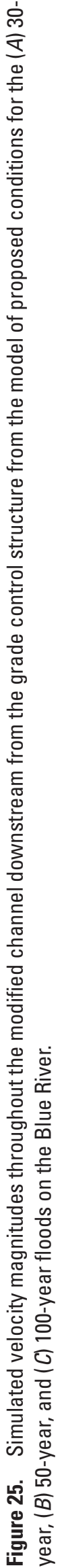


peak discharges on these tributaries likely will not coincide with the peak on the mainstem; as a result, the tributary channels become areas of slack water, and the simulated velocity magnitudes are essentially zero.

Flow from the left flood plain reaches a maximum of about $14.8 \mathrm{ft} / \mathrm{s}$ as it reenters the main channel through a relatively narrow drain for the 50-year flood (lower middle of fig. $25 B$ and upper left of fig. $23 B$ ) and nearly $24.5 \mathrm{ft} / \mathrm{s}$ for the 100-year flood (lower middle of fig. $25 C$ and upper left corner of fig. 23C). The location of this drain is near the downstream end of the left trail levee along the left side of the GCS and riprap stilling basin, and it is an area that may warrant additional consideration for placement of riprap.

Flow from the industrial park into the large fill area along Brighton Avenue on the left flood plain reaches a maximum velocity of $10.1 \mathrm{ft} / \mathrm{s}$ in the 50-year flood and $14.8 \mathrm{ft} / \mathrm{s}$ in the 100 -year flood (lower middle of figs. $25 B$ and $25 C$, respectively). The overall decrease in water surface in the modified downstream channel and the increase in water surface upstream from the GCS cause this to be an area of substantial lowering in the water surface for these two floods (figs. $11 B$ and $11 C$ ).

\section{Summary}

The Blue River Channel Modification project being implemented by the U.S. Army Corps of Engineers (USACE) is intended to provide flood protection within the Blue River valley in the Kansas City, Mo., metropolitan area. The project consists of channel modifications, concrete paving, and rockor stone-protected slopes with a capacity designed to convey the 30-year flood frequency discharge. Construction began in 1983 and has progressed upstream from the mouth at the Missouri River, and the next phase of the project involves work from Brush Creek upstream to 63d Street. Preservation of the Civil War historic area of Byram's Ford and the associated Big Blue Battlefield, while also providing flood protection for the Byram's Ford Industrial Park, is of key concern in this phase of the project.

The USACE used a physical model built at the Waterways Experiment Station (WES) in Vicksburg, Miss., to examine the feasibility of a proposed grade control structure (GCS) that would be placed downstream from the historic crossing to provide a subtle transition of flow from the natural channel to the modified channel. As part of a recent flood inundation study along the Blue River in Kansas City, the U.S. Geological Survey (USGS) in cooperation with the city of Kansas City, Mo., developed a two-dimensional hydrodynamic flow model for the part of the river between 63d Street and Blue Parkway (the "original model") using the depthaveraged Finite Element Surface-Water Modeling System (FESWMS Flo2DH). The USGS, in cooperation with the USACE, simulated the existing unimproved channel and the proposed channel modifications and grade control structure and analyzed the results from the simulations and those from the WES physical model.

Modifications were made to the existing two-dimensional hydrodynamic flow model developed between 63d Street and Blue Parkway (the "original model") to create a model that represents conditions as they exist currently (2006) between the north end of Swope Park (immediately upstream from 63d Street) and the upstream limit of channel improvement on the Blue River (the "model of existing conditions"). The model of existing conditions was calibrated to two measured floods. Further modifications were made to the model of existing conditions to create a model that represents conditions along the same reach of the Blue River with proposed channel modifications and the proposed grade control structure (the "model of proposed conditions"). The models of existing conditions and proposed conditions were used to simulate the 30-, 50-, and 100 -year recurrence floods. The discharge from the calibration flood of May 15, 1990, also was simulated in the models of existing and proposed conditions to provide results for that flood with the current downstream channel modifications and with the proposed channel modifications and GCS.

Results from the model of existing conditions show that the downstream channel modifications as they currently (2006) exist may already be affecting flows in the unmodified upstream channel. The 30-year flood does not inundate most of the Byram's Ford Industrial Park near the upstream end of the study area. Analysis of the 1990 flood (with the historical 1990 channel conditions) and the 1990 flood simulated with the existing (2006) conditions indicates a substantial increase in velocity throughout the study area and a substantial decrease in inundated area from 1990 to 2006.

Results from the model of proposed conditions show that the proposed channel modifications will contain the 30-year flood and most of the 50-year flood as well. The spoil berm designed to provide additional flood protection of the Byram's Ford Industrial Park for the 30-year flood prevents inundation of the industrial park. In the vicinity of Byram's Ford for the 30-year flood, the maximum depth increased from 39.7 feet (ft) in the model of existing conditions to $43.5 \mathrm{ft}$ in the model of proposed conditions, with a resulting decrease in velocity from 6.61 to 4.55 feet per second (ft/s). For the 50-year flood, the maximum depth increased from 42.3 to $45.8 \mathrm{ft}$, with a decrease in velocity from 6.12 to $4.16 \mathrm{ft} / \mathrm{s}$ from existing to proposed conditions. For the 100-year flood, the maximum depth increased from 44.0 to $46.6 \mathrm{ft}$, with a decrease in velocity from 5.64 to $4.12 \mathrm{ft} / \mathrm{s}$ from existing to proposed conditions. When the May 15, 1990, discharge was simulated in the model of existing conditions (with the current (2006) modified downstream channel), the maximum depth increased from 38.4 to $42.0 \mathrm{ft}$, with a decrease in velocity from 6.54 to $4.84 \mathrm{ft} / \mathrm{s}$ from existing to proposed conditions.

Analysis of the results from the May 15, 1990, flood (with historical 1990 channel conditions) and the model of proposed conditions indicates that the maximum depth increased from 41.5 to $42.0 \mathrm{ft}$, with a decrease in velocity from 5.09 to $4.84 \mathrm{ft} / \mathrm{s}$ from historical (1990) to proposed condi- 
tions. While these results are further confirmation that the downstream channel modifications as they currently exist may already be affecting flows in the unmodified upstream channel, they also show that the proposed GCS likely will create conditions similar to those that existed before downstream channel modifications began.

Direct analysis of the velocities in the riprap stilling basin downstream from the GCS in the model of proposed conditions and the WES physical model was not possible because of the depth-averaged nature of the results from FESWMS Flo2DH, but general trends were similar between the model of proposed conditions and the WES physical model. The maximum velocity in the riprap stilling basin occurred in the center of the channel immediately downstream from the concrete stilling basin of the GCS and decreased in a downstream direction.

Velocity magnitudes in the modified channel downstream from the GCS were remarkably consistent throughout the range of discharges examined, with the average velocity along the centerline ranging from 7.4 to $7.7 \mathrm{ft} / \mathrm{s}$. A localized maximum velocity of nearly $24.5 \mathrm{ft} / \mathrm{s}$ was simulated for the 100 year flood at the downstream end of the left trail levee where flow from the flood plain reenters the channel. Other localized contractions of flow on the left flood plain resulted in velocities as great as $14.8 \mathrm{ft} / \mathrm{s}$ for the 100 -year flood.

\section{References Cited}

Arcement, G.J., Jr., and Schneider, V.R., 1989, Guide for selecting Manning's roughness coefficients for natural channels and flood plains: U.S. Geological Survey Water-Supply Paper 2339, 38 p.

Barnes, H.H., Jr., 1967, Roughness characteristics on natural channels: U.S. Geological Survey Water-Supply Paper 1849,213 p.

Brunner, G.W., 2002, HEC-RAS, River analysis system hydraulic reference manual: U.S. Army Corps of Engineers Hydrologic Engineering Center CPD-69, 350 p.
Chow, V.T., 1959, Open-channel hydraulics: St. Louis, Mo., McGraw-Hill Publishing Company, 678 p.

City of Kansas City, Department of Public Works, 2004, Blue Parkway over Blue River and Union Pacific railroad bridge replacement-Preliminary bridge plans: City of Kansas City, Project No. BRM-3417, Bridge No. S010B11.

Cooper, R.D., 1996, Grade control structure for Blue River, Kansas City, Missouri, April 1996: U.S. Army Corps of Engineers Waterways Experiment Station Technical Report HL-96-15, 220 p.

Environmental Modeling Research Laboratory, 1999, Surface-water modeling system reference manual, version 8.0: Provo, Utah, Brigham Young University, 315 p.

Froehlich, D.C., 2002, Two-dimensional depth-averaged flow and sediment transport model-Users manual for FESWMS Flo2DH: Federal Highway Administration, FHWA-RD-03053, 203 p.

Kelly, B.P., and Rydlund, P.H., Jr., 2006, Estimated floodinundation mapping for the Lower Blue River in Kansas City, Missouri, 2003-05: U.S. Geological Survey Scientific Investigations Report 2006-5089, 27 p.

Huizinga, R.J., and Rydlund, P.H., Jr., 2001, Simulation of flow and evaluation of bridge scour at Horse Island Chute Bridge near Chester, Illinois: U.S. Geological Survey WaterResources Investigations Report 01-4176, 28 p.

Missouri Department of Transportation, 1935, Bridge over railroads and Big Blue River: Jefferson City, Missouri State Highway Department, Project No. WPGM 3-73F (U.S. 50), Bridge No. K-500.

U.S. Army Corps of Engineers, 2004, Blue River channel modification project: Kansas City District, U.S. Army Corps of Engineers, http://www.nwk.usace.army.mil/ projects/blueriver/index.htm, accessed March 1, 2007. 
For more information concerning the research described in this report, contact:

U.S. Geological Survey

Missouri Water Science Center

1400 Independence Road

Rolla, MO 65401

(573) 308-3667

http://mo.water.usgs.gov 

8 Printed on recycled paper 